\title{
U.S. GEOLOGICAL SURVEY \\ WATER RESOURCES ACTIVITIES IN FLORIDA, 1987-88
}

By Mildred E. Glenn, Editor

U.S. GEOLOGICAL SURVEY

Open-File Report 88-199

\section{IN COOPERATION WITH}

Florida Dept. of Environmental Regulation

Florida Dept. of Natural Resources

Florida Dept. of Transportation

Collier Mosquito Control District

Englewood Water District

Loxahatchee River Environmental Control District

Northwest Florida Water Management District

St. Johns River Water Management District

South Florida Water Management District

Southwest Florida Water Management District

Suwannee River Water Management District

South Dade Soil \& Conservation Water District

Reedy Creek Improvement District

Florida Keys Aqueduct Authority

Metro-Dade Environmental Resources Management

Miami-Dade Water \& Sewer Authority

Palm Beach County Solid Waste Authority

Suwannee River Authority

Tampa Port Authority

West Coast Regional Water Supply Authority

Florida Institute of Phosphate Research

Game and Freshwater Fish Commission

Brevard County Board of Commissioners

Broward County Environ. Quality Control Board

Broward County

Collier County

Metro-Dade County

Hillsborough County

Indian River County

Lake County

Lee County

Leon County

Manatee County

Marion County

Palm Beach County

Pinellas County

Polk County

St. Johns County

\author{
Sarasota County \\ Sumter County \\ Volusia County \\ Walton County \\ City of Boca Raton \\ City of Bradenton \\ City of Cape Coral \\ City of Clearwater \\ City of Cocoa \\ City of Cottondale \\ City of Fort Lauderdale \\ City of Fort Walton Beach \\ City of Hallandale \\ City of Hollywood \\ City of Jacksonville \\ City of Lakeland \\ City of Madison \\ City of Perry \\ City of Pompano Beach \\ City of Port Orange \\ City of Quincy \\ City of St. Petersburg \\ City of Sanibel \\ City of Sarasota \\ City of Stuart \\ City of Tallahassee \\ Electric Department \\ Streets \& Drainage \\ Underground Utilities \\ Water Quality Lab \\ City of Tampa \\ Town of Highland Beach \\ University of Florida \\ National Park Service \\ U.S. Air Force \\ U.S. Corps of Engineers \\ U.S. Dept. of Energy
}

Tallahassee, Florida 
DEPARTMENT OF THE INTERIOR

DONALD PAUL HODEL, Secretary

U.S. GEOLOGICAL SURVEY

Dallas L. Peck, Director

Eor additional information write to:

District Chief

U.S. Geological Survey Suite 3015

227 North Bronough Street

Tallahassee, Florida 32301
Copies of this report can be purchased from:

U.S. Geological Survey Books and Open-File Reports Section Federal Center Box 25425

Denver, Colorado 80225 


\section{F O R E W O R D}

The U.S. Geological Survey was created by an Act of Congress in 1879, as a bureau of the Department of the Interior, to classify public lands and to examine the geologic structure, mineral resources, and products of the national domain. Since then, the Survey's responsibilities have expanded to include topographic mapping, geochemical and geophysical studies, and the assessment of the quantity, quality, and distribution of water resources. Thus, during the past 100 years, the Survey has become the Nation's principal factfinding and research agency concerned with our physical resources. The mission of the Water Resources Division of the Survey is to provide hydrologic information needed for the development, management, and use of the Nation's water resources.

Although stream gaging began in 1884 as part of a study to identify irrigatable land, the water-resources program of the Survey began in 1894 when a small appropriation was obtained for the specific purpose of "gauging streams and determining the water supply of the United States." In the years following 1884 , the need for water resources information grew rapidly but the inability of the Survey to meet the demand was hampered by restricted budgets. Many states initiated water resource programs to fill the deficiency and the Survey worked closely with the various state agencies. However, these efforts did not satisfy the need of the states and the Nation for a comprehensive water resources information program. Accordingly, Congress, in 1928, established the cooperative matching program by which the Survey's water resources programs with state agencies may be funded on a 50/50 basis. This cooperative water resources program has grown over the years into the primary source of water information for the Nation. In cooperation with State and local governments and other Federal agencies, the Water Resources Division -.

- Collects data on a systematic basis to determine the quantity, quality, and use of surface and ground water.

- Conducts interpretive water-resource appraisals to describe the consequences of alternative plans for developing land and water resources.

- Conducts basic and problem-oriented research in hydraulics, hydrology, and related fields.

- Develops information on water-related natural hazards such as floods, landslides, volcanoes, mudflows, and land subsidence.

- Coordinates the activities of all Federal agencies in the acquisition of water data.

- Disseminates data and findings through reports, maps, and other forms of public release.

Provides scientific and technical assistance in the hydrologic fields to other Federal agencies, to State and local agencies, and, on behalf of the U.S. Department of State, to international agencies.

Water Resources, National Mapping, and Geologic Divisions are the three operating Divisions of the Survey. General information pertaining to these divisions may be obtained from the Information office, U.S. Geological Survey, 119 National Center, Reston, VA 22092. Circular 900, "A Guide to Obtaining Information from the U.S. Geological Survey" can be obtained free from the U.S. Geological Survey, Books and Open-File Reports Section, Federal Center, Box 25425, Denver, Colorado 80225. 


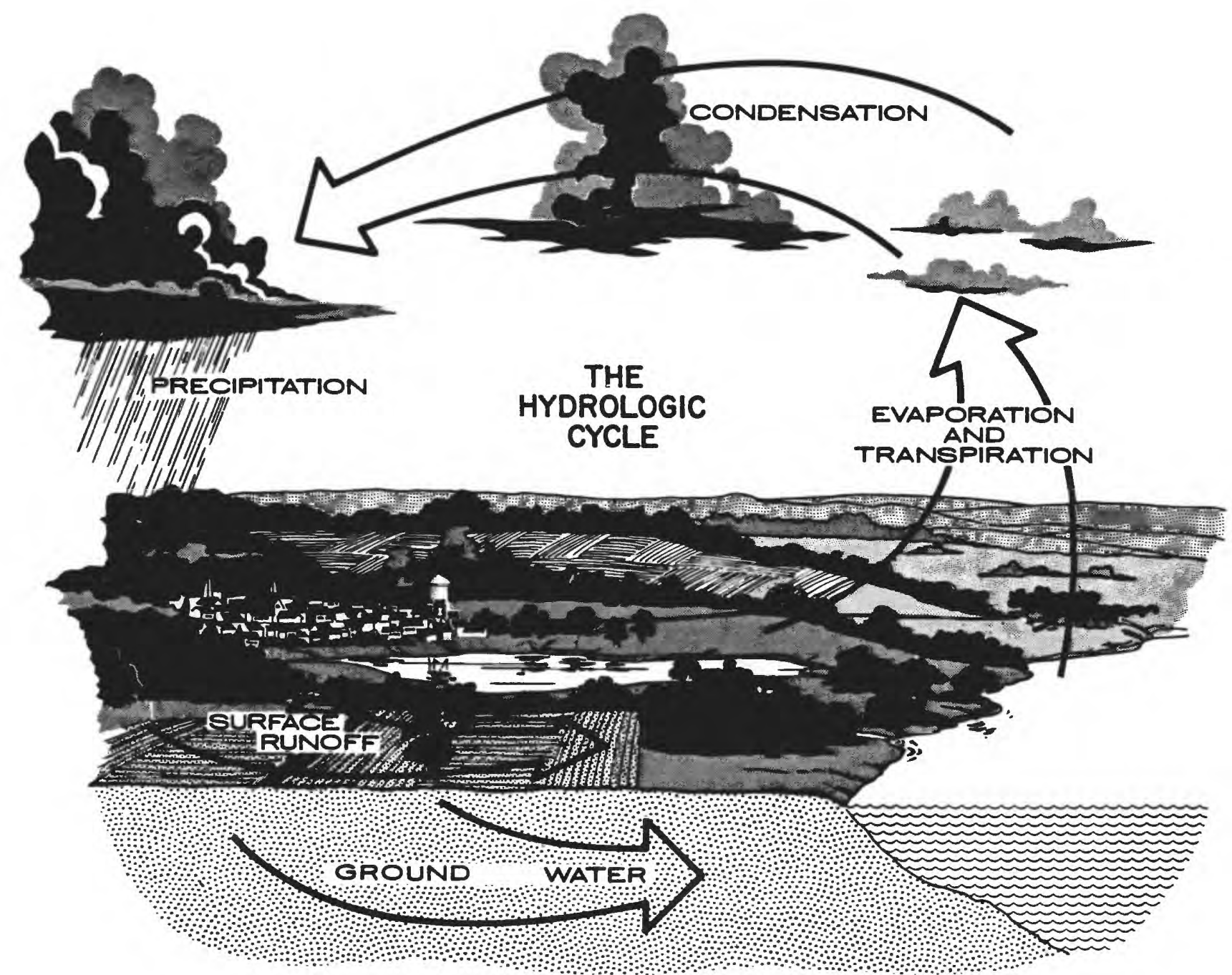




\section{CONTENTS}

Page

Foreword............................... III

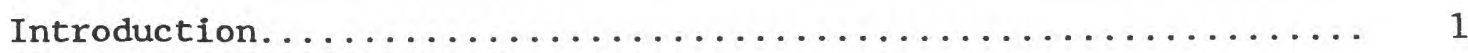

U.S. Geological Survey Water Resources Division programs........ 3

National Water-Data Exchange (NAWDEX) $\ldots \ldots \ldots \ldots \ldots \ldots \ldots \ldots \ldots$

National Water-Data Storage and Retrieval

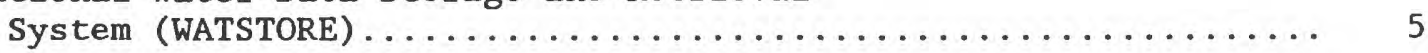

Distributed Information System (DIS) $\ldots \ldots \ldots \ldots \ldots \ldots \ldots \ldots \ldots \ldots$

National Stream Quality Accounting Network (NASQAN) .......... 7

New reports from the U.S. Geological Survey,

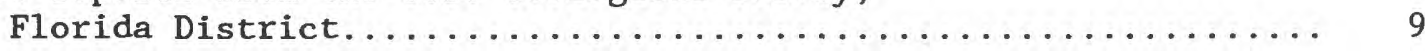

How to obtain reports prepared by the Florida District........ 13

Florida Water Resources Research Center................. 14

Hydrologic data stations in Florida as of September 1987....... 15

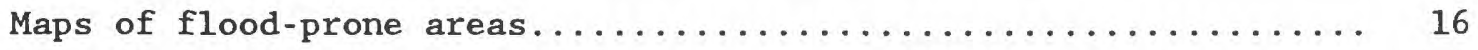

Location of areal investigations and the five water
management districts $\ldots \ldots \ldots \ldots \ldots \ldots \ldots \ldots \ldots \ldots \ldots \ldots \ldots \ldots$

Water resources activities in Florida, $1987-88 \ldots \ldots \ldots \ldots \ldots \ldots \ldots$

Summaries of Florida water resources activities............ 21 


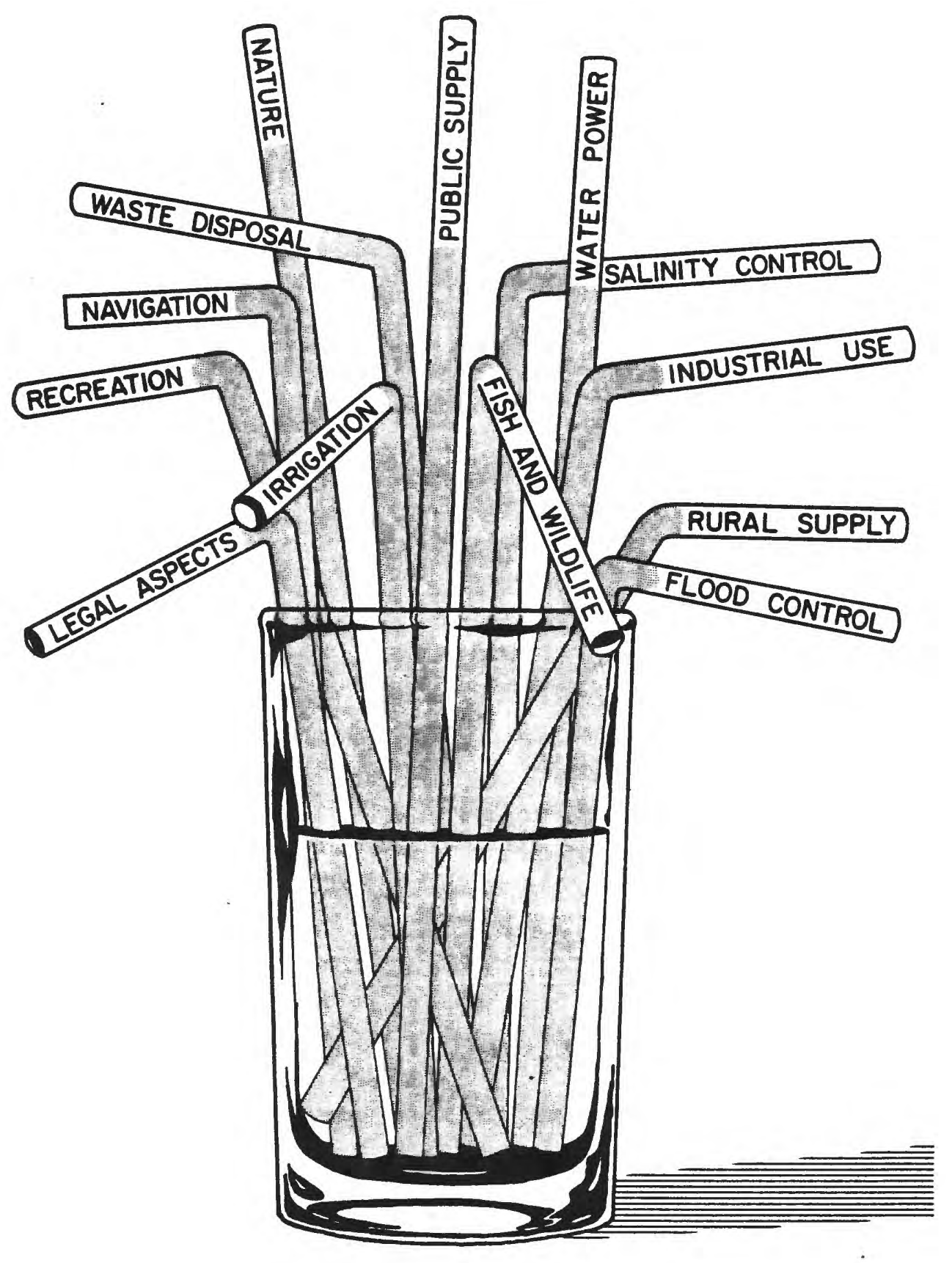

Competition for water is growing. Adequate information and analysis are keys to effective development, protection, and management of a common water resource. 


\title{
WATER RESOURCES ACTIVITIES IN FLORIDA, 1987-88
}

\author{
By Mildred E. Glenn, editor
}

I N T RODUCTION

This report contains summary statements of water resources activities in Florida conducted by the Water Resources Division of the U.S. Geological Survey in cooperation with Federal, State, and local agencies during 1987 88. These activities are part of the Federal program of appraising the Nation's water resources. Included are brief descriptions of the nature and scope of all active studies, summaries of significant results for 1987 and anticipated accomplishments during 1988.

Florida is a water oriented State which for many years has experienced a mushrooming increase in population, attendant urban growth, and all the problems associated with such growth, particularly problems of protecting and preserving environmental quality. As the Florida environment is largely water sensitive, most environmental problems are water related. The Florida District of the U. S. Geological Survey has the principal responsibility at the Federal level for appraising water resources and for providing basic hydrologic data on both surface and ground water in the State.

Water resources appraisals in Florida are highly diversified, ranging from hydrologic records networks to interpretive appraisals of water resources and applied research to develop investigative techniques. Thus, water resource investigations range from basic descriptive wateravailability studies for areas of low-intensity water development and management to sophisticated cause and effect studies in areas of highintensity water development and management. The interpretive reports and records that are products of the investigations are a principal hydrologic foundation upon which the plans for development, management, and protection of Florida's water resources may be based.

The need for water resources information is especially great in urbanized areas, where concern is being expressed that the "carrying" capacity of the land and water resources is being exceeded. Increasingly intensive and sophisticated water-management programs will have to be implemented in these urban areas to meet the increasing needs for water and to maintain good water quality. Water data and information required to implement sound water-management programs in highly urbanized areas relate to the quantity and quality of storm runoff, sources of aquifer contamination, injection of wastes into deep strata, underground storage of freshwater, artificial recharge of aquifers, environmental effects of reuse of water, and effects of land development on changes in ground- and surface-water quality. In some parts of the State broad areas are largely rural. Future growth is anticipated in many of these. However, recognition is given to the need for planned development tailored to the environment. The need for water information in these rural areas is related to a large extent to the need to provide for primary water development and provide information on effects of development. 
This report is intended to inform those agencies vitally interested in the water resources of Florida as to the current status and objectives of the U. S. Geological Survey cooperative program. The mission of this program is to collect, interpret, and publish information on water resources. Almost all of this work is done in cooperation with other public agencies.
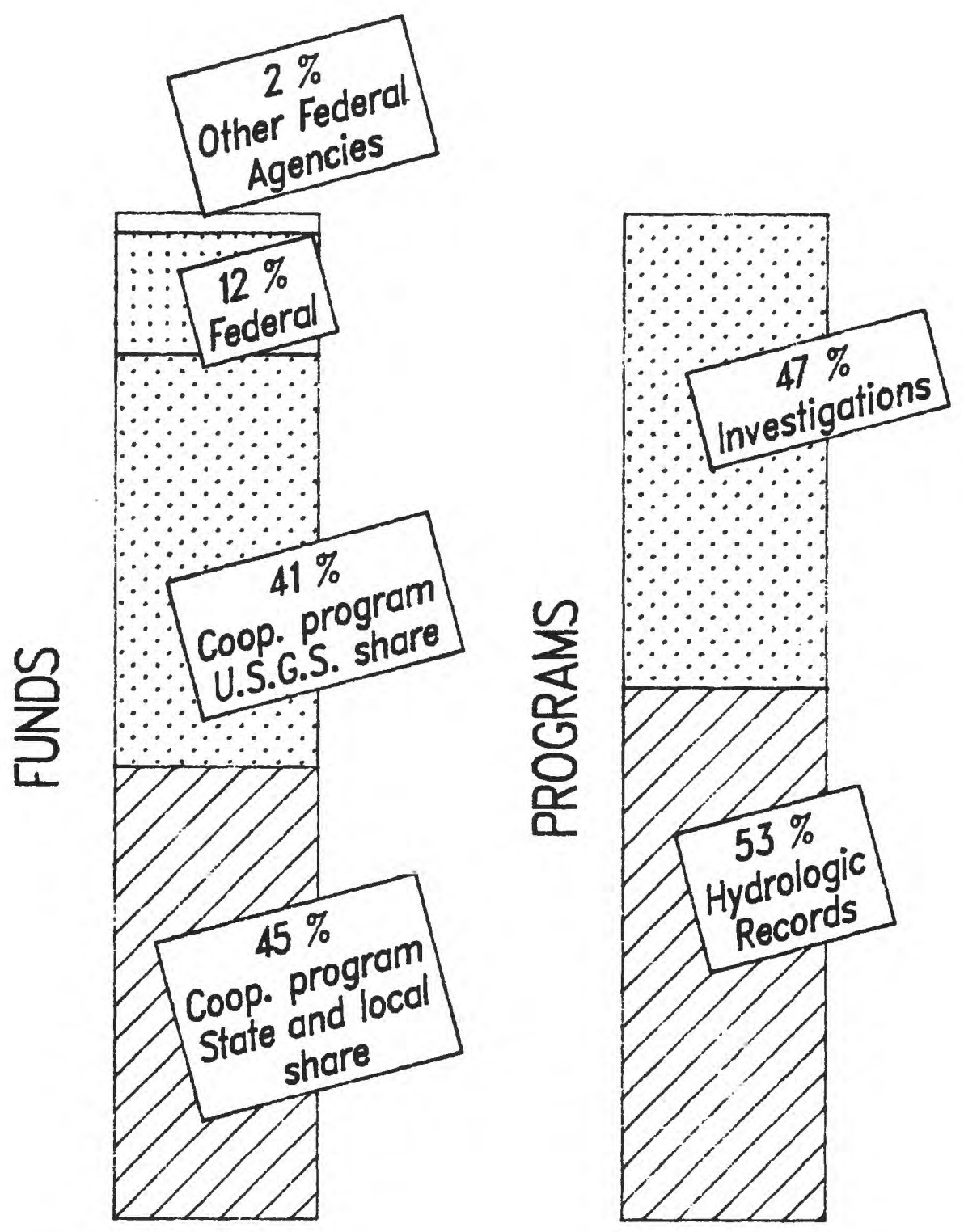

Source of funds and makeup of program, Florida District 1987-88. 


\section{U. S. GEOLOGICAL SURVEY}

\section{WATER RESOURCES DIVISION PROGRAMS}

Program development in the Water Resources Division is an evolving activity. Programs are reviewed regularly and future needs for water-data and hydrologic investigations are projected. Water problems and data needs brought out by State and local agencies and the public make up a major part of the planning process; thus, program development is a grassroots effort which is strongly influenced by changes in data needs and water problems.

Water Resources Division programs are of three major types: (a) data collection and dissemination, (b) problem-oriented water-resources appraisals, and (c) research. The programs are strongly interrelated; for example, theories arising from research are the foundation of data collection and problem-oriented water-resources appraisals, and data collection is a major component of all water-resources appraisals and most of the research studies.

The Division's activities may be described under three headings: 1ongterm programs, technical-assistance programs, and topical programs.

Long-term programs include the Federal-State cooperative program; coordination of Federal water-data acquisition; assistance to other Federal agencies; the National Research Program; the National Water-Data Exchange; the Water Resources Scientific Information Center; the National Water-Use Information Program; the hydrologic data-collection program, including the national stream quality accounting network and the national benchmark program; and the international hydrology program. These programs are fundamental to the Division's mission and they provide the data and research needed for the topical programs.

Topical programs are designed to provide critically needed information on issues of major and immediate concern to the Nation. These programs include hazardous waste hydrology, including high- and low-level nuclear and toxic-chemical wastes; coal and oil-shale hydrology; regional aquifer systems analysis; acid rain; volcano subsidence, and flood hazards; and a nationwide water-quality assessment.

Technical-assistance programs include the instrumentation program, a central water-quality laboratory, and the national training center. These programs are internal to the Division but contribute significantly to the continuing development of hydrologic capabilities and thus to the success of the Division's mission. 
NATIONAL WATER-DATA EXCHANGE

(N A W D E X)

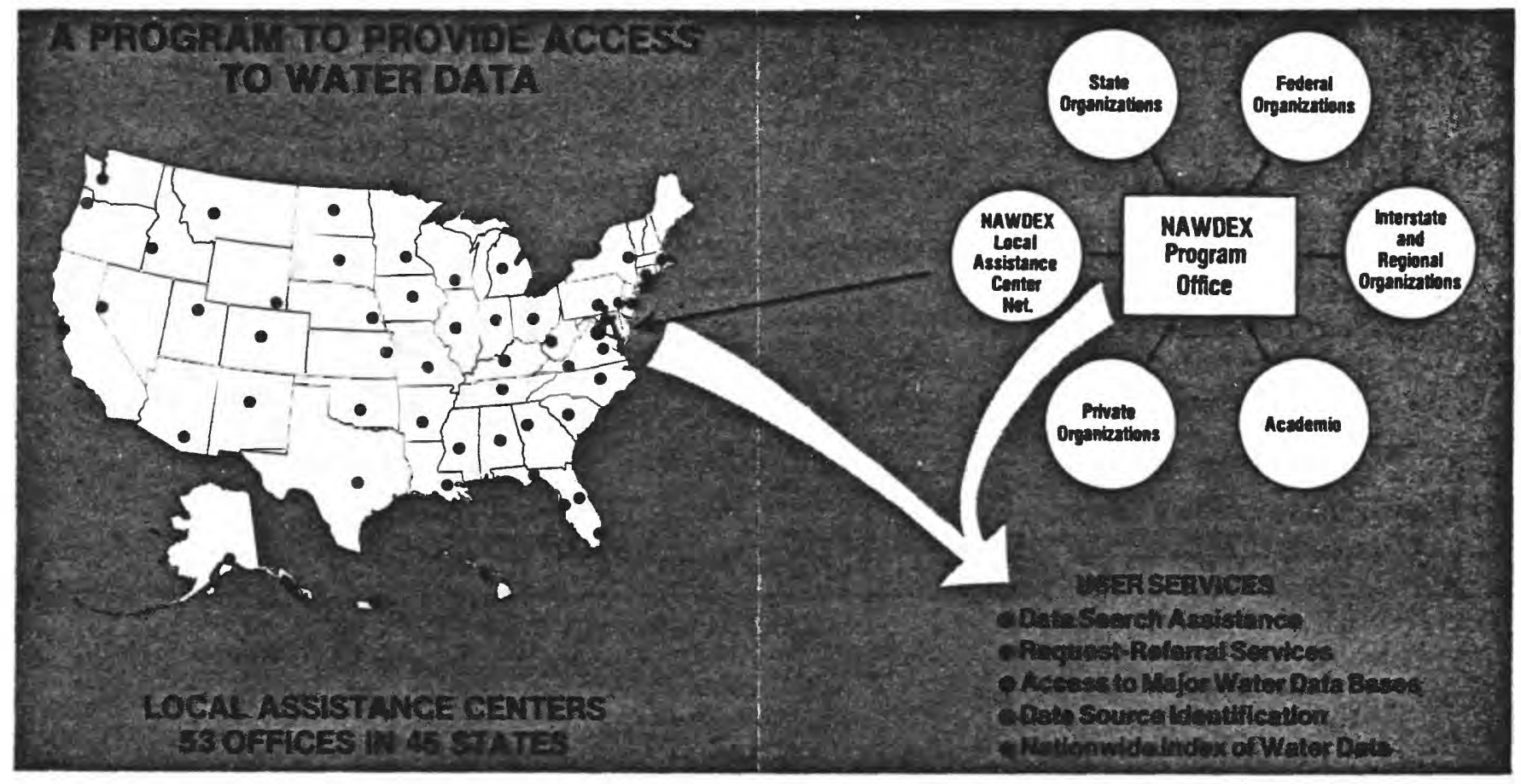

The National Water-Data Exchange (NAWDEX) is a nationwide program managed by the U.S. Geological Survey to assist users of water data or water-related data in identifying, locating, and acquiring needed data. NAWDEX is a confederation of water-oriented organizations working together to make their data more readily accessible and to facilitate a more efficient exchange of water data.

A variety of user services are provided by NAWDEX. These include assistance in identifying and locating needed water data and referring the requester to the organization that retains the data required. A Water Data Sources Directory is also maintained that identifies organizations that are sources of water data and locations within these organizations from which data may be obtained. NAWDEX services are available to any organization or individual. Further information can be obtained from the NAWDEX Program Office, MS-421, National Center, Reston, VA 22092 (703)648-6848. 


\section{NATIONAL WATER-DATA STORAGE AND RETRIEVAL SYSTEM (W A T S TOR E)}
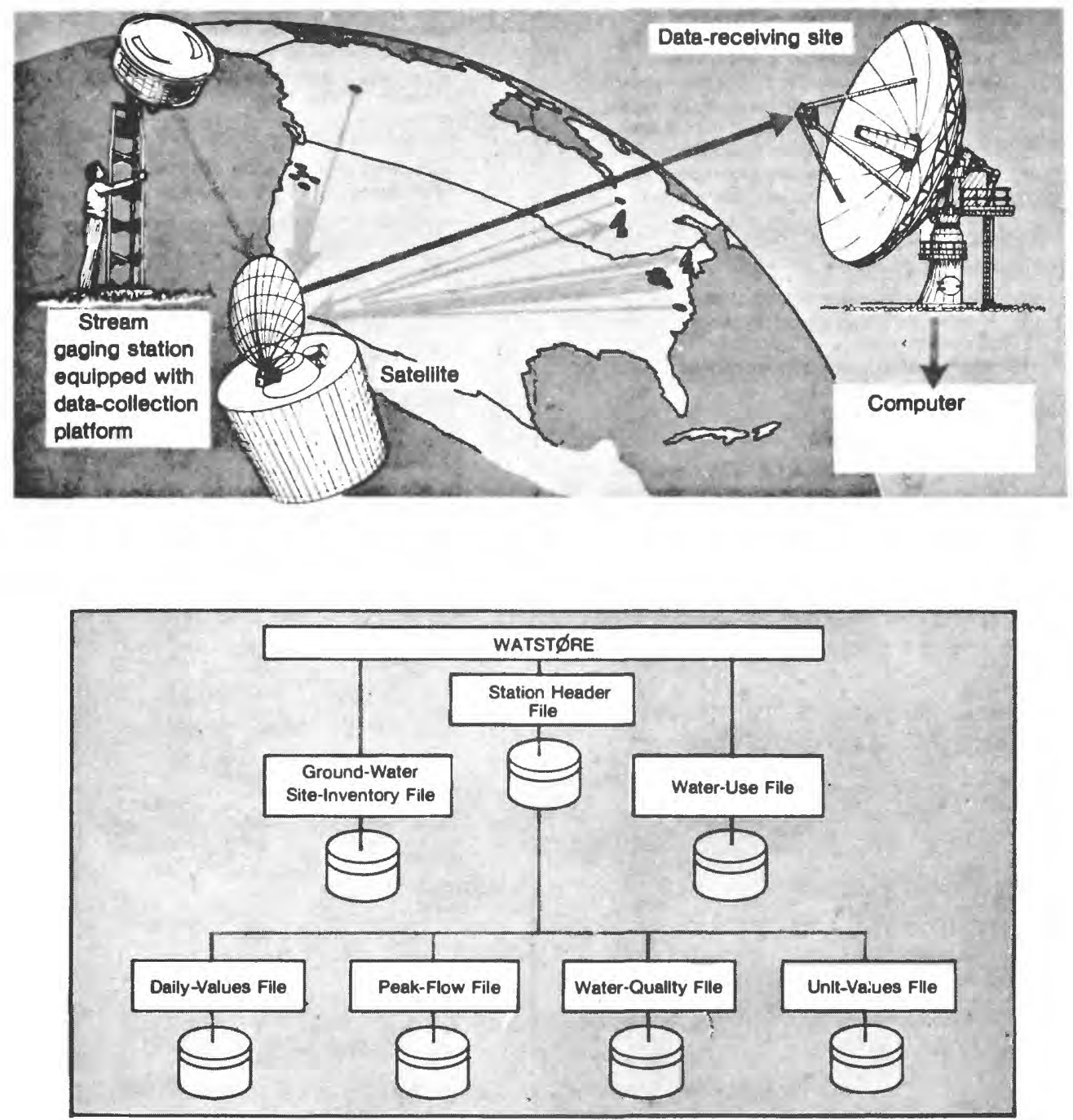

As part of the Geological Survey's program of releasing water data to the public, a large-scale computerized system has been developed for the storage and retrieval of water data collected through its activities. The National Water Data Storage and Retrieval System (WATSTORE) was established in 1971 to modernize the Geological Survey's existing water-data processing procedures and techniques and to provide for more effective and efficient management of its data-releasing activities. Data are transferred monthly from WATSTORE to the Environmental Protection Agency's storage and retrieval system (STORET). In Florida, WATSTORE data products may be obtained through the Survey's District and Subdistrict offices listed on the inside front cover. A minimal fee plus the actual computer cost incurred in producing a desired product is charged to the requester. 


\section{DISTRIBUTED INFORMATION SYSTEM}

(DIS)

The Survey has developed a Distributed Information System (DIS) to enhance the management and availability of water resources data. The DIS is a nationwide network of 75 computers located in major Water Resources Division offices and linked by a telecommunication network. The Florida DIS consists of computers in Miami, Orlando, Tallahassee, and Tampa and a telecommunication network linking 9 Florida USGS offices with Water Management Districts and other cooperating agencies. This system has greatly improved the Survey's data base management, statistical analysis, and modeling capabilities as well as providing unprecedented access to water resources information.

To provide increased flexibility in the use of water resources information, the USGS WATSTORE Program Office is developing a data base using a hydrologic data model designed to enhance data sharing. Residing at DIS sites in Florida, the National Water Data System (NWDS) data base will integrate surface water, ground water, water quality, water use, meteorologic, and operations data giving users a comprehensive view. Statistical, graphical, and simulation procedures will be available to provide additional information.

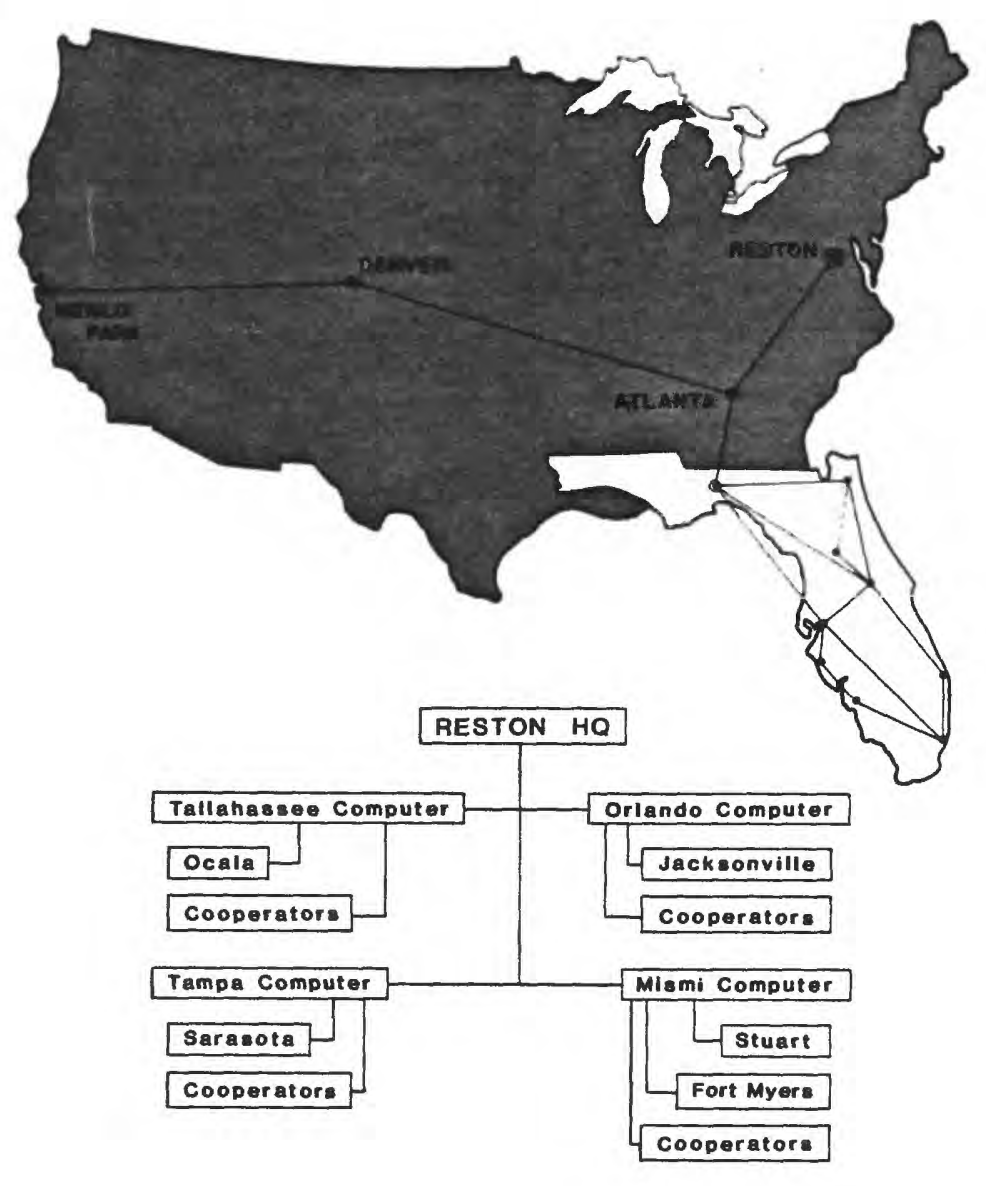




\section{THE NATIONAL STREAM QUALITY ACCOUNTING NETWORK}

( $N$ A $\quad S \quad Q \quad A \quad N)$

NASQAN is a series of stations at which systematic and continuing measurements are made to determine the quality of the Nation's streams. Design of the network specifies measurement of a broad range of water-quality characteristics selected to meet many of the information requests of groups involved in planning and management on a national or regional scale. The primary objectives are: (1) to account for the quantity and quality of water moving within and from the United States, (2) to depict areal variability, (3) to detect changes in stream quality, and (4) to lay the groundwork for future assessments of changes in stream quality.

Presently in Florida, 22 NASQAN and one hydrologic benchmark sites are strategically located in virtually all major hydrologic accounting units within the State and furnish a regionalized picture of water-quality trends in Florida's surface waters.

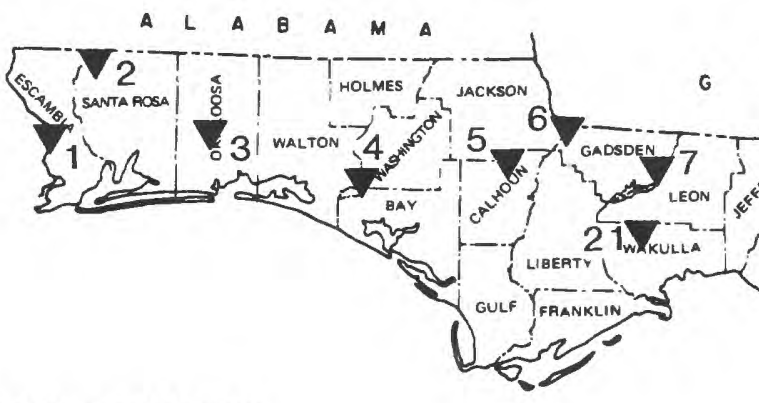

\section{NASQAN STATIONS}

1. Perdido River at Barrineau Park

2. Escambia River near Century

3. Yellow River at Milligan

4. Choctawhatchee River near Bruce

5. Chipola River near Altha

6. Apalachicola River at Chattahoochee

7. Ochlockonee River near Havana

8. Suwannee River at Branford

9. St. Johns River near Deland

10. Spruce Creek near Samsula

11. Withlacoochee River near Holder

12. Alafia River at Lithia

13. Main Canal at Vero Beach

14. Kissimmee River at S65E near Okeechobee

15. Peace River at Arcadia

16. Fisheating Creek near Palmdale

17. Caloosahatchee Canal at Otona Lock near Labelle

18. Miami Canal at NW 36th Street, Miami

19. Tamiami Canal-40 mile bend to Monroe

20. Santa Fe River at Worthington Springs

21. Sopchoppy River near Sopchoppy (hydrologic benchmark station)

22. Oklawaha River near Conner 


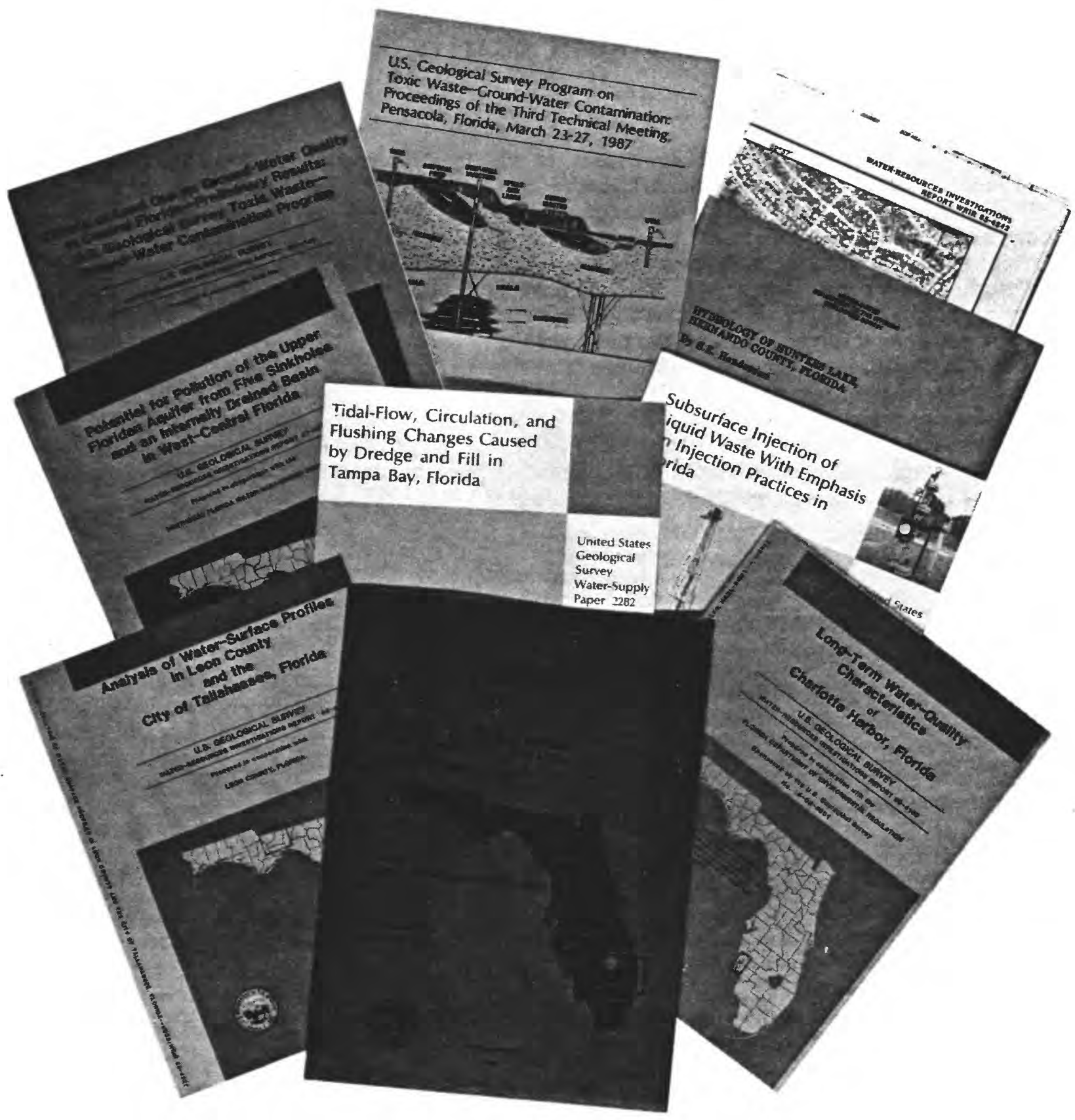

More than 35 reports were released during 1987 and more than 1,000 requests for reports were received. 


\section{NEW REPORTS FROM TIE U.S. GEOLOGICAL SURVEY}

\section{FLORIDA DISTRICT}

The results of many of the water resources activities of the U.S. Geological Survey are released in reports for use by water agencies and the public. Survey reports on the water resources of Florida are available for inspection at the offices listed on the inside of the front cover, at the offices of the five water management districts, and at libraries of the State University system. Contact the District Office for information regarding the availability of these publications.

Aucott, W.R., The predevelopment ground-water flow system and hydrologic characteristics of Coastal Plain aquifers of South Carolina: U.S. Geological Survey Water Resources Investigations Report 86-4347.

Barr, G.L., Potentionmetric surface of the Upper Floridan aquifer in Florida, May 1985 (for State publication by FDER, FBOR, and FDNR).

Bradner, L.A., Potsntiometric surface of the Upper Floridan aquifer in central Sumter County, Florida, September 1986: U.S. Geological Survey Open-File Report 87-34.

Bradner, L.A., Potentiometric surface of the Upper Floridan aquifer, in the St. Johns River Water Management District and vicinity, Florida, September 1987: U.S. Geological Survey Open-File Report 87-688.

Corral, M.A. Jr., and Thompson, T. H., Hydrology of the Citrus Park quadrangle, Hillsborough County, Florida: U.S. Geological Survey Water Resources Investigations Report 87-4166.

Duerr, A.D., Hunn, J.D., Lewelling, B.R., and Trommer, J.T., Geohydrology and 1985 water withdrawals of the aquifer systems in southwest Florida, with emphasis on the intermediate aquifer system: U.S. Geological Survey Water Resources Investigations Report 87-4259.

Elder, J.F., Trace metal biogeochemistry in surface-water systems: A review of current understanding: U.S. Geological Circular

Elder, J.F., and Dresler, P.V., Accumulation and bioconcentration of polycyclic aromatic hydrocarbons in a nearshore estuarine environment near a Pensacola (Florida) creosote contamination site. (Journal Article)

Fish, J.E., Hydrogeology, transmissivity, and ground-water flow of the surficial aquifer system, Broward County, Florida: U.S. Geological Survey Water Resources Investigations Report 87-4034.

Foose, D.W., Long-term stage records of selected lakes in Florida (for State publication by FDER, FDNR, FBOG)

Franks, B.J., Hydrology and flow of water in a sand and gravel aquifer contaminated by wood-preserving compounds, Pensacola, Florida: U.S. Geological Survey Water Resources Investigations Report 87-4260. 
Franks, B.J., U.S. Geological Survey program on toxic waste-ground-water contamination: Proceedings of the third technical meeting, Pensacola, Florida, March 22-23, 1987 . (Abstracts)

Fretwe11, J.D., Water resources and effects of ground-water development in Pasco County, Florida: U.S. Geological Survey Water Resources Investigations Report 87-4260.

German, E.R., Quantity and quality of stormwater runoff recharged to the Floridan aquifer system through two drainage wells in the Orlando, Florida, area: Water supply paper.

German, E.R., Quantity and quality of drainage-well inflow in Orlando, Florida (Conference Paper).

German, E.R., and Bradner, L.A., Artificial recharge of ground water, Orlando, Florida (Oral Presentation)

German, E.R., and Schiffer, D.M., Application of National Stream Quality Accounting Network (NASQAN) station data for assessing water quality in the Peace River basin, Florida, 1974-82: U.S. Geological Survey Water Resources Investigations Report 87-4167.

Glenn, M.E., U.S. Geological Survey Water Resources Activities for Florida: U.S. Geological Survey Open-File Report 87-244.

Hammett, K.W., Land use, water use, streamflow, and water-quality characteristics of the Charlotte Harbor inflow area: U.S. Geological Survey Open-File Report 87-472 and WSP.

Hampson, P.S., and Coffin, J.E., Measurement of reaeration coefficients for selected Florida streams and evaluation of predictive equations for stream reaeration coefficients: U.S. Geological Survey Water Resources Investigations Report 87-4020.

Hickey, J.J., Hydraulic gradients in variable-salinity ground water (Abstract).

Hickey, J.J., Limitations of the equivalent freshwater head approach to the field study of variable-salinity ground water (Proceedings of Meeting).

Hickey, J.J., Convective circulation during subsurface injection of liquid waste (Conference Proceedings).

Hickey, J.J., Convective circulation during subsurface injection of liquid waste (Abstract).

Higer, A.L. and Kolipinski, M.C., Changes of vegetation in Shark River Slough, Everglades National Park, Florida, 1940-64 (Symposium Proceedings).

Kimrey, J.W., Artificial recharge of ground water and its role in water management (Conference Proceedings). 
Klein, Howard, and Ratzlaff, K.W., Changes in saltwater intrusion in the Biscayne aquifer, Hialeah-Miami Springs area, Dade County, Florida: U.S. Geological Survey Water Resources Investigations Report 87-4020.

Lee, T.M., and Winter, T.C., Ground-water interactions in a sinkhole lake in central Florida (Abstract).

Lewelling, B.R., Potentiometric surface of the Upper Floridan aquifer, westcentral Florida, September 1986: U.S. Geological Survey Open-File Report $86-603$.

Lewelling, B.R., Potentiometric surface of the intermediate aquifer system, west-central Florida, September 1986: U.S. Geological Survey Open-File Report 87-35.

Lewelling, B.R., Potentiometric surface of the intermediate aquifer system, west-central Florida, May 1987: U.S. Geological Survey Open-File Report $87-705$.

Lewelling, B.R., Potentiometric surface of the Upper Floridan aquifer, westcentral Florida, September 1987: U.S. Geological Survey Open-File Report $87-683$.

Martin, E.H., Effectiveness of detention on stormwater quality (Journal Article).

Martin, E.H. and Miller, R.A., Efficiency of an Urban stormwater detention system. (Abstract)

Mattraw, H.C., Jr., Scheidt, D.J., and Federico, A.C., Analysis of trends in water-quality data for water conservation area $3 \mathrm{~A}$, the Everglades, Florida: U.S. Geological Survey Water Resources Investigations Report 874142 .

Meyer, F.W., Hydrogeology, ground-water movement, and subsurface storage in the Floridan aquifer system in southern Florida: Professional Paper 1403G.

Miller, R.L., Kraemer, T.F., and McPherson, B.F., Origin of ${ }^{228} \mathrm{Ra},{ }^{226} \mathrm{Ra}$, and $222 \mathrm{Rn}$ in Charlotte Harbor estuary, Florida, with estimates of groundwater inflow using ${ }^{226} \mathrm{Ra}$ and salinity data. (Journal Article)

Navoy, A.S., and Bradner, L.A., Ground-water resources of Flagler County, Florida: U.S. Geological Survey Water Resources Investigations Report 87-4021.

Phelps, G.G., Effects of surface runoff and treated wastewater recharge on quality of water in the Floridan aquifer system, Gainesville area, Alachua County, Florida: U.S. Geological Survey Water Resources Investigations Report 87-4099.

Russell, G.M., and Goodwin, C.R., Simulation of tidal flow and circulation patterns in the Loxahatchee River estuary, southeastern Florida: U.S. Geological Survey Water Resources Investigations Report 87-4201. 
Russel1, G.M., and Higer, A.L., Assessment of ground-water contamination along the eastern perimeter of the Lantana landfill, Palm Beach County, Florida. (Journal Article)

Sonntag, W.H., Chemical characteristics of water in the surficial aquifer system, Dade County, Florida: U.S. Geological Survey Water Resources Investigations Report 87-4080.

Spechler, R.M., Potentiometric surface of the Upper Floridan aquifer in the St. Johns River Water Management District and vicinity, Florida, September 1986: U.S. Geological Survey Open-File Report 87-36.

Swayze, L.J., Ground-water flow beneath levee 35A from Conservation Area 2B, Broward County, Florida: U.S. Geological Survey Water Resources Investigations Report 87-4280.

Trommer, J.T., Potential for pollution of the Upper Floridan aquifer from five sinkholes and an internally drained basin in west-central Florida: U.S. Geological Survey Water Resources Investigations Report 87-4013.

Waller, B.G., Effectiveness of the water-management system in reducing flood damage in South dade County (Miami), Florida. (Journal Article)

Waller, B.G., and Howie, Barbara, Determining nonpoint-source contamination by agricultural chemicals in an unconfined aquifer, Dade County, Florida: Procedures and preliminary results. (Conference Paper)

Waller, B.G., Howie, Barbara, and Causaras, C.R., Effluent migration from septic tank systems in two different Iithologies, Broward County, Florida: U.S. Geological Survey Water Resources Investigations Report $87-4075$.

Wolansky, R.M. and Thompson, T.H., Relation between ground water and surface water in the Hillsborough River basin, west-central Florida: U.S. Geological Survey Water Resources Investigations Report 86-4010. 


\section{IIOW TO OBTAIN REPORTS PREPARED BY TIIE FLORIDA DISTRICT}

The Florida District has been preparing reports on water resources for several decades. Titles of new reports prepared by the Florida District are included in the free monthly catalog, "New Publications of the U.S. Geological Survey." To subscribe, write to:

New Publications of the Geological Survey

U.S. Geological Survey

582 National Center

Reston, VA 22092

For information on availability of reports, please write to the istrict Chief, U.S. Geological Survey, Suite 3015, 227 North Bronough Street, Ta11ahassee, Florida 32301.

PUBLICATION SERIES

OPEN-FILE REPORTS

(Florida)

WATER-RESOURCES INVESTIGATIONS

(Florida)

\section{CONTACT}

U.S. Geological Survey

Suite 3015

227 N. Bronough Street

Tallahassee, FL 32301
U.S. GEOLOGICAL SURVEY BOOKS

Bulletins

Circulars

Professional Papers

Water-Supply Papers

U.S. GEOLOGICAL SURVEY MAPS

Hydrologic Investigations Atlases

Hydrologic Unit Maps

\section{FLORIDA GEOLOGICAL SURVEY}

Bulletins

Map Series

Reports of Investigations

Information Circulars
U.S. Geological Survey

Books and Open-File Reports Section Box 25425, Federal Center

Denver, CO 80225

U.S. Geological Survey

Map Distribution

Box 25286, Federal Center

Denver, CO 80225

Florida Geological Survey

(fomerly Bureau of Geology)

$903 \mathrm{~W}$. Tennessee Street

Tallahassee, FL 32304 


\section{FLORIDA WATER RESOURCES RESEARCH CENTER}

The Florida Water Resources Research Center, funded by the Department of the Interior, was established in 1964 as a result of the passage of Public Law 88-379--The Water Resources Research Act of 1964--" to stimulate, sponsor, provide for, and supplement present programs for conduct of research, investigation, experiments, and the training of scientists in the fields of water and of resources which affect water." Late in 1983, management of this program was transferred to the U.S. Geological Survey.

Under the administration of the Center, current water resources research pertaining to the achievement of adequate statewide water resource management, and water quality and quantity is being conducted by faculty at the University of Florida and at other universities in the State. For further information concerning the Center, contact Dr. James P. Heaney, Director, Florida Water Resources Research Center, 424 A.P. Black Hall, University of Florida, Gainesville, FL 32611 (904) 392-0840. A list of new publications resulting from the center projects is presented below:

No. 96 GAZETTEER OF FLORIDA LAKES by M.D. Shafer, R.E., Dickinson, J.P. Heaney, and W.C. Huber, 1986.

No. 97 SOUTHWEST FLORIDA WATER MANAGEMENT DISTRICT AGRICULTURAL WATER USE DATA BASE (SAWUD) by M.C. Hancock and J.P. Heaney, 1987.

No. 98 ECONOMIC AND PREDICTIVE RELIABILITY IMPLICATIONS OF STORMWATER DESIGN METHODOLOGIES by B.A. Cunningham and W.C. Huber, 1987.

No. 99 COMPUTER-AIDED ENGINEERING APPROACH TO AGRICULTURAL FLOOD HAZARD MANAGEMENT IN FLORIDA by L. B. Baldwin, K. L. Campbe1l, A.B. Bottcher, J. Capece, R. Burlesdon, and R. Taylor, 1987. 


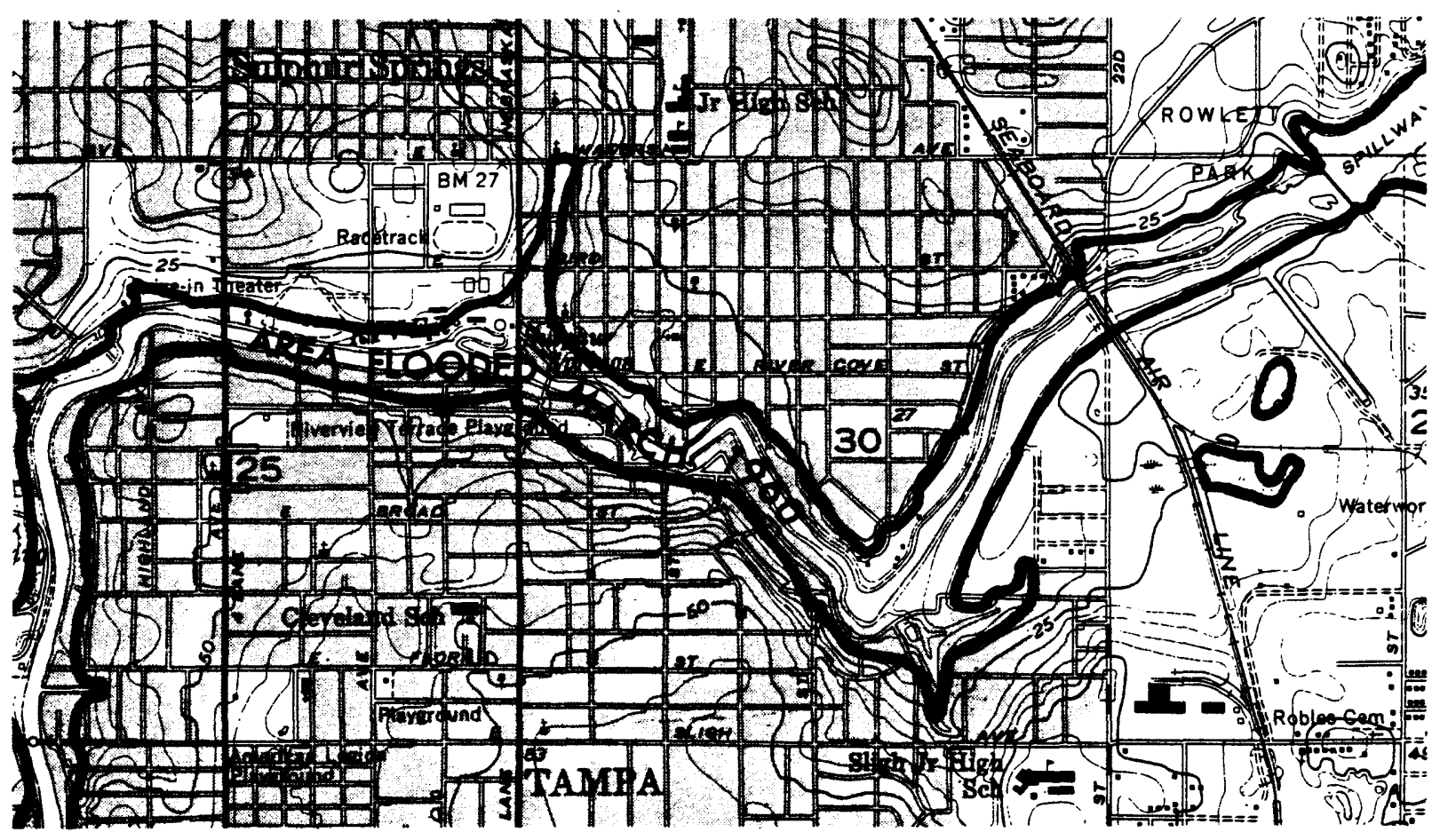

Flooms in the United States cause an average yearly loss of about 80 lives an $\$ 1$ billion. Improvements in flood forecasting and rapid communicatices have decreased the number of lives lost in recent years, but the dollar lass and the tragedy of damaged or lost homes are increasing.

The flow of a river is usually confined to a well-defined channel that meanders through the river valley. However, at times the river overflows because of heavy rains and uses the wide, flat areas adjacent to the channel to carry a part of the flow. During a major flood, this flood plain may be covered to a depth of many feet with water moving at a high velocity.

The flood plain may appear to be an attractive area for development, particularly in urban communities where land is expensive. Many housing projects and commercial and industrial buildings have been constructed on the flood plains because people tend either to forget past experiences or to be unaware of possible flood danger.

A national program for reducing flood losses was started by the Federal Government in 1966. As a part of this program, the U.S. Geological Survey outlined flood-prone areas on topographic maps to indicate localities that may be subject to flood losses. For Florida, these maps can be obtained through the Florida Resources and Environmental Analysis Center, Room 361, Bellamy Building, Florida State University, Tallahassee, FL 32306, Telephone: (904) 644-2883. Flood-prone areas for most counties and cities in Florida have been defined by detailed studies or by approximate methods and maps of these areas are available (free) through: Federal Emergency Management Agency, Flood Map Distribution Center, 6930 (A-F) San Tomas Road, Baltimore, MD 21227-6227, Telephone: (800) 638-6620 (toll free). 


\section{LOCATION OF AREAL INVESTIGATIONS AND THE}

FIVE WATER MANAGEMENT DISTRICTS

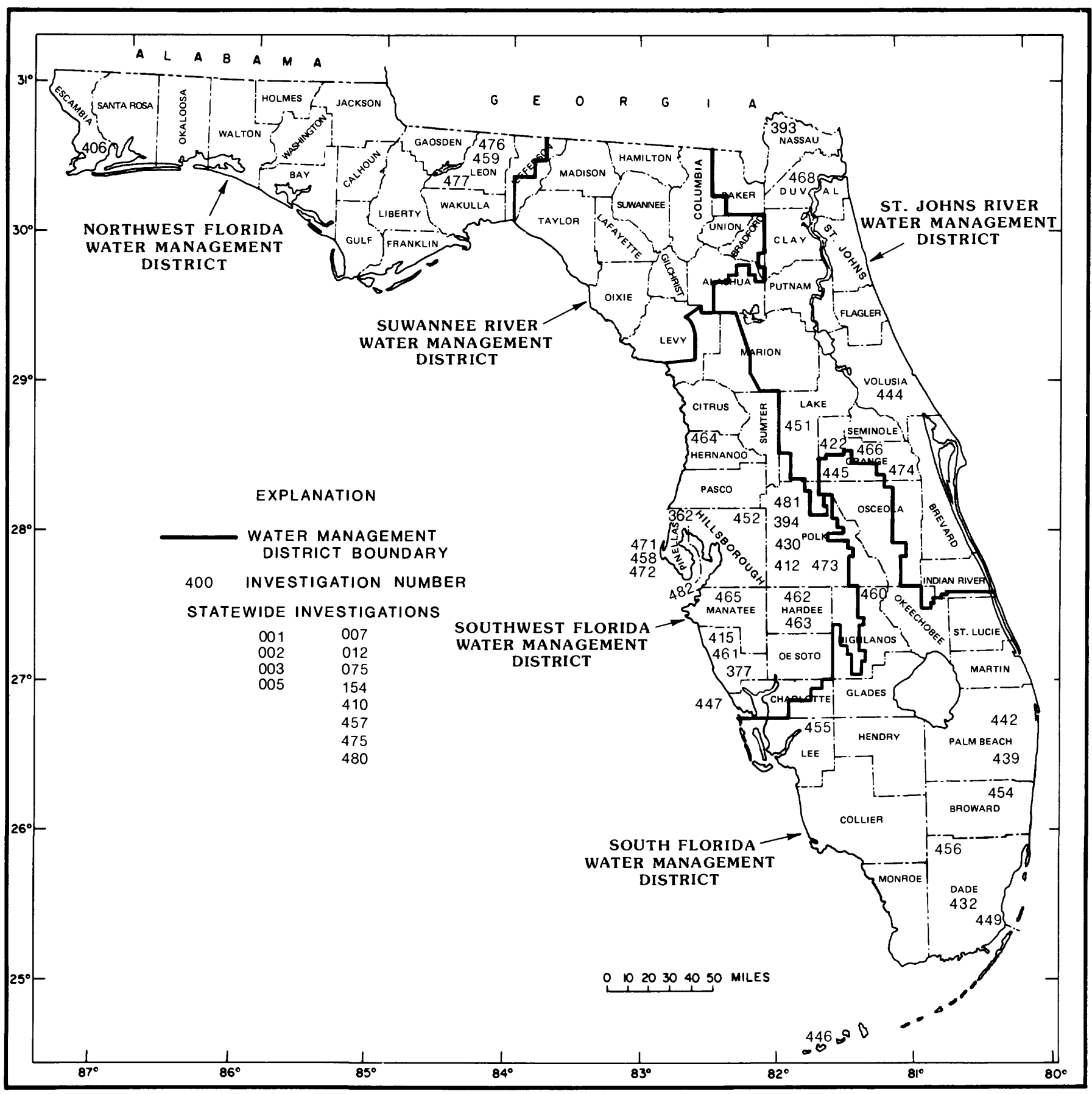




\section{U.S. GEOLOGICAL SURVEY \\ WATER RESOURCES ACTIVITIES IN FLORIDA, 1987-88}

Number

Title

Page

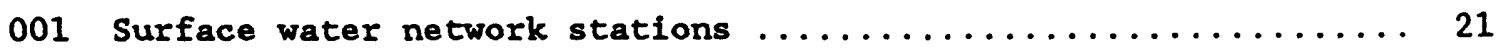

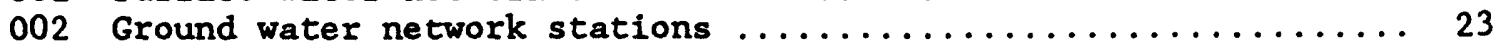

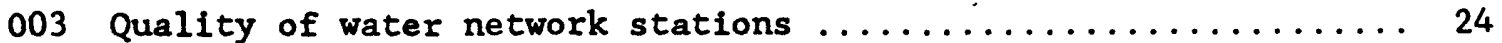

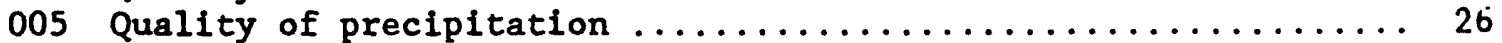

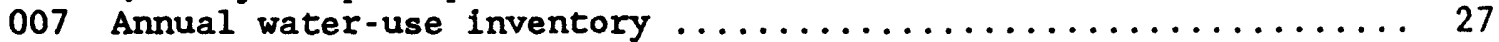

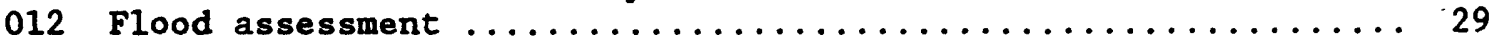

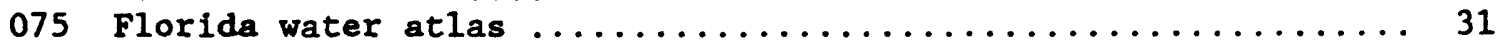

154 Subsurface waste storage, Florida ................... 35

362 Evaluation of stormwater detention basins in westcentral Florida ............................. 39

377 Environmental assessment study of the Charlotte Harbor estuarine system and surrounding area, southwest Florida ................................... 40

393 Flow characteristics of Nassau River basin and estuary ............................... 42

406 Occurrence, movement, and fate of organic contaminants in ground water near Pensacola, Florida .............. 43

410 Adaptation of Floridan aquifer system RASA models for water-management needs, Florida ................ 45

412 Simulation approaches to understanding ground-water surface-water relationships and water budgets in

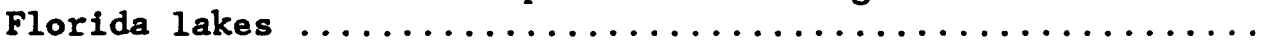

415 Assessment of hydrogeological conditions and alternatives for safeguarding water quality in southwest Sarasota

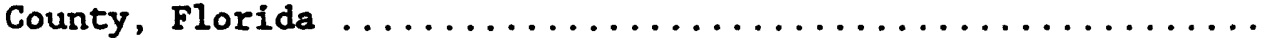

422 Impacts of selected developmental activities on the quality of ground water, central Florida.............. 51

430 Geological controls on ground-water movement and contamination in Polk County, Florida .............. 53

432 Effects of sludge on ground-water quality, Dade County, Florida....................... 55

439 Numerical simulation of the migration of landfill leachate in a highly permeable surficial aquifer,

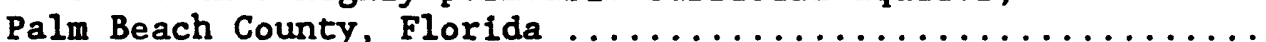

442 Effects of septic tanks and domestic wells on water quality and levels, northeast Palm Beach County,

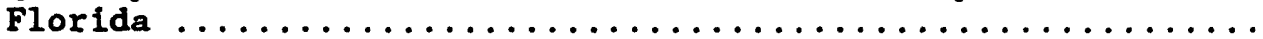

444 Geohydrology of the surficial aquifer system,

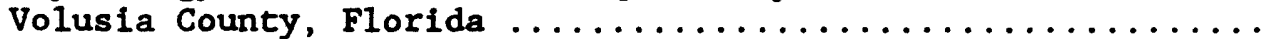

445 Assessment of water-quality processes affecting nutrients in wetlands stream .................... 60

446 Water resources evaluation of the freshwater lens

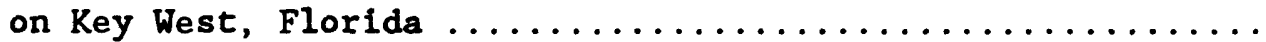

447 Salinity characteristics and effects of freshwater withdrawals, Myakka River, Florida 
449 Simulation of a saltwater plume from a flowing well in a surficial aquifer, Dade County, Florida ............ 63

451 Nutrient loads in the Apopka-Beauclair Canal, upper Oklawaha basin, central Florida................... 65

452 Delineation of protection zones around public-supply

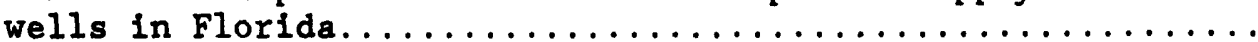

Waste contamination using a geographical information

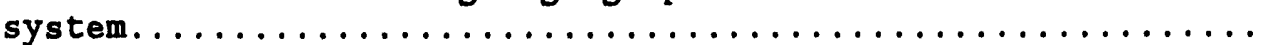

455 Feasibility of storing freshwater in subsurface formations, Cape Coral, Lee County, Florida............. 70

456 Impact of pumping at the northwest well field on adjacent wetlands, Dade County, Florida............... 71

457 Low-flow characteristics of Florida streams.............. 72

458 Saltwater-freshwater interface in the coastal area

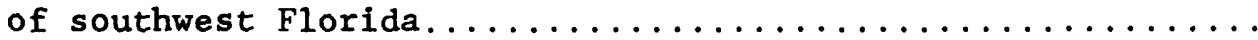

459 Sources of nitrogen in ground water from areas subject to application of wastewater by spray irrigation and commercial fertilizers near Tallahassee, Florida............

Ground water hydrology of the surficial and Floridan aquifer systems in Osceola and Okeechobee County......... 76

461 Evapotranspiration from areas of native vegetation

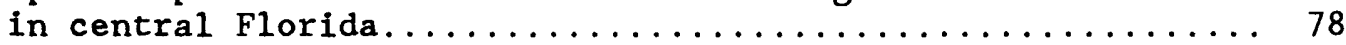

462 Potentionmetric maps of the intermediate aquifer system, west-central Florida, summary of hydrologic

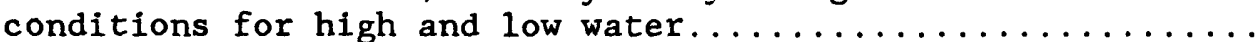

463 Hydrology and water quality of the intermediate and Upper Floridan aquifers, Hardee and DeSoto Counties,

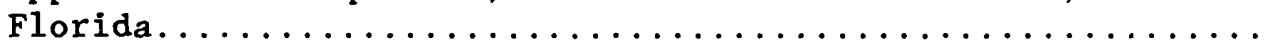

464 Saltwater intrusion in springs along the coastal margin of Citrus and Hernando Counties, Florida.......... 81

465 Potential for contamination of the Floridan aquifer

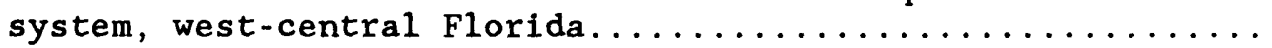

466 Floridan aquifer system water quality in an area of drainage-well inflow........................... 84

468 Water resources of Duval County, Florida................

471 Ground-water quality in the vicinity of stormwater

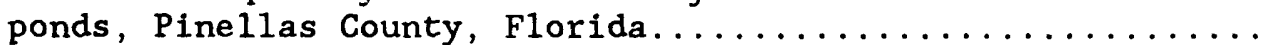

472 Hydrogeological assessment of spray effluent and sludge disposal basins at a disposal site, Pinellas County,

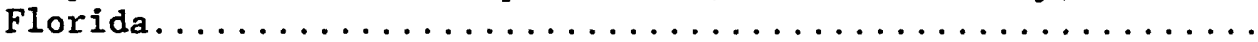
ydrologic impacts of phosphate mining on small basins,

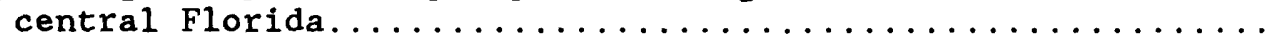

474 Effects of structural changes on the water-quality

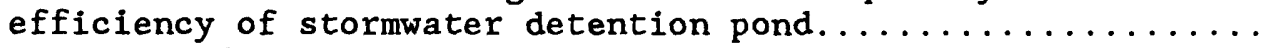

475 Evaluation of the design of ground water quality

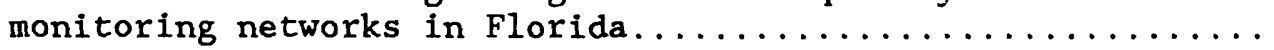

476 Importance of hydrologic and vegetative factors to fish ecology in a seasonally inundated flood-plain forest........

477 An evaluation of various physical and biological indicators
used to delineate wetland boundaries on blackwater stream

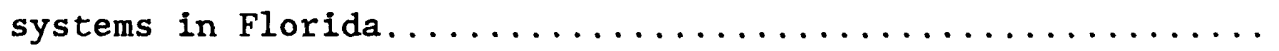


479 Impacts of a migrating citrus industry on the water resources of Hardee and DeSoto Counties, Florida....... 95

480 Evaluation of the ambient ground-water monitoring network for describing background water quality in Florida......... 96

481 The relative importance of ground water to the chemical budget of seepage lakes....................... 97

482 Fine sediment resuspension processes and light attenuation

in shallow estuarine environments.................. 98 
DATE PROJECT BEGAN: 1926

DATE PROJECT ENDS: Continuing

PROJECT COORDINATOR: W. C. Bridges, Tallahassee

PRINCIPAL AREA INVESTIGATORS: L. D. Fayard, Orlando; W. J. Haire, Miami; R.

T. Mycyk, Tampa; M. A. Franklin, Tallahassee

COOPERATING AGENCIES: Most of the agencies shown in the list of cooperators.

PROBLEM: Surface-water information is needed for purposes of surveillance, planning, design, hazard warning, operation, and management in water-related fields such as water supply, flood control, irrigation, bridge and culvert design, wildlife management, pollution abatement, flood-plain management, and water resources development. To provide this information, an appropriate data base is necessary.

OBJECTIVE: To obtain and document an unbiased inventory of streamflow, stream and lake stage data for use in the planning and development of the water resources of the State of Florida.

APPROACH: Collect stream discharge, stream and lake stage data from a network of gaging stations that include daily discharge, periodic discharge, daily stage, and periodic stage stations to define streamflow and stage conditions within the State of Florida.

PROGRESS: Streamflow and stage data were collected from 683 network sites and prepared for publication. Streamflow and stage data currently are being obtained at the number of hydrologic data network stations given below.

Station Classification

Stream stations

Continuous record:

Discharge and Stage....... 310

Stage Only.............. 85

Partial record:

Peak (maximum) flow........ 70

Periodic Streamflow......... 51

Lake and reservoir stations.........

Stage and contents.......... 2

Stage only

Continuous............. 68

Periodic............. 71

Number of Stations

516

141

657 
(FL-001)

PLANS FOR.THIS YFAR: Continue operations as needs are defined.

REPORTS IN PROCESS:

Water-resources data for Florida, water year 1987.

REPORTS RBILASED:

U.S. Geological Survey, 1987, Water resources data for Florida-1986, northeast Florida: U.S. Geological Survey Water-Data Report FL-86-1A.

U.S. Geologlcal Survey, 1987, Water resources data for Florida-1986, south Florida Surface Water: U.S. Geological Survey Water-Data Report FL-86$2 A$.

U.S. Geological Survey, 1987, Water resources data for Florida-1986, southwest Florida Surface Water: U.S. Geological Survey Water-Data Report FL86-3A.

U.S. Geological Survey, 1987, Water resources data for Florida-1986, northwest Florida: U.S. Geological Survey Water-Data Report FL-86-4. 


\section{FL-002 GROUND WATER NETWORK STATIONS}

DATE PROJECT BEGAN: 1930

DATE PROJECT ENDS: Continuing

PROJECT COORDINATOR: W. C. Bridges, Tallahassee

PRINCIPAL AREA INVESTIGATORS: L. D. Fayard, Orlando; W. J. Haire, Miami; R. T. Mycyk, Tampa; M. A. Franklin, Tallahassee

COOPERATING AGENCIES: Most of the agencies shown in the list of cooperators

PROBLEM: Long term water level records are needed to evaluate the effects of climatic variations on the recharge to and discharge from the groundwater systems, to provide a data base from which to measure the effects of development, to assist in the prediction of future supplies, and to provide data for management of the resource.

OBJECTIVE: To obtain and document an unbiased inventory of water-level data for use in the planning and development of the water resources of the State of Florida.

APPROACH: Collect water-level data for the various aquifers by a network of observation wells which includes 1,624 periodic observations sites and 470 sites where data are recorded continuously.

PROGRESS: Water-leve1 data were collected and published as planned.

PLANS FOR THIS YEAR: Collection and publication of data will be continued.

REPORTS IN PROCESS:

Water-resources data for Florida, water year 1987.

\section{REPORTS RELEASED:}

U.S. Geological Survey, 1987, Water resources data for Florida-1986, northeast Florida: U.S. Geological Survey Water-Data Report FL-86-1B.

U.S. Geological Survey, 1987, Water resources data for Florida-1986, south Florida Surface Water: U.S. Geological Survey Water-Data Report FL-86$2 \mathrm{~B}$.

U.S. Geological Survey, 1987, Water resources data for Florida-1986, southwest Florida Surface Water: U.S. Geological Survey Water-Data Report FL- $86-3 B$.

U.S. Geologica1 Survey, 1987, Water resources data for Florida-1986, northwest Florida: U.S. Geological Survey Water-Data Report FL-86-4. 
FL-003 QUALITY OF WATER NETWORK STATIONS

DATE PROJECT BEGAN: 1939

DATE PROJECT ENDS: Continuing

PROJECT COORDINATOR: W. C. Bridges, Tallahassee

PRINCIPAL AREA INVESTIGATORS: L. D. Fayard, Orlando; W. J. Haire, Miami; R. T. Mycyk, Tampa; M. A. Franklin, Tallahassee

COOPERATING AGENCIES: Most of the agencies shown in the list of cooperators

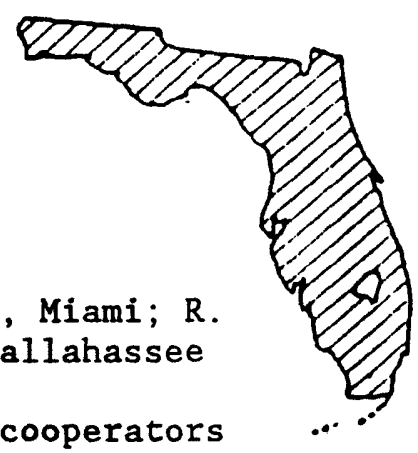

PROBLEM: Water resource planning and water-quality assessment require a nationwide base level of relatively standardized information. For intelligent planning and realistic assessment of the water resource, the chemical and physical quality of surface and ground waters must be defined and monitored.

OBJECTIVE: To obtain and document unbiased inventory of water-quality data for use in the planning and development of the water resources of the State of Florida.

APPROACH: Collect water-quality data from a network of daily, weekly, and periodic stations which include streams, lakes, springs, and wells to define water quality conditions within the State of Florida.

PROGRESS: Water-quality data are obtained at 185 surface-water network stations. These stations are used to monitor the quality of surface water in Florida. Some of these stations also are part of a U.S. Geological Survey nationwide network known as the National stream Quality Accounting Network which is used to detect nationwide trends in water quality. The types of data determined at these sites are given below. Inasmuch as several types of data may be determined at a particular site and not all types of data are determined at each site, the number given below will not equal the total number of surface water sites.

Data Classification

Physical data:

Temperature, specific conductance or $\mathrm{ph} . \ldots \ldots \ldots \ldots \ldots \ldots \ldots \ldots \ldots \ldots . \ldots \ldots$

Number of Sites

Sediment. ....................

Chemical data:

Inorganic constituents............ 99

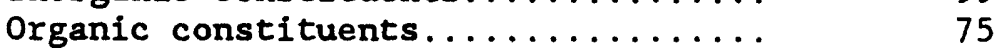

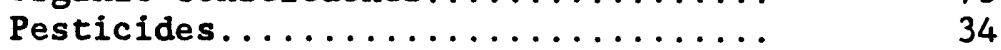

Radiochemical data.............. 0

Biological data............... 17 
(FL-003)

Water-quality data are obtained at network observation wells and springs. The types of data determined at these sites are listed below. Inasmuch as several types of data may be determined at a particular site, and not all types of data are determined at each site, the number given below will not equal the total number of ground water sites.

Data Classification Wells Springs

Physical data:

Temperature, specific conductance or pH.... $699 \quad 7$

Chemical data:

Inorganic constituents.............. 91 5

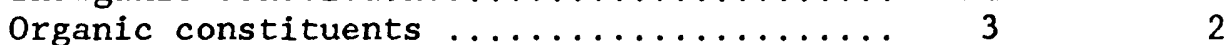

Biological data................. $12 \quad 1$

REPORTS IN PROCESS:

Water-resources data for Florida, water year 1987.

REPORTS RELEASED:

U.S. Geological Survey, 1987, Water resources data for Florida-1986, northeast Florida: U.S. Geological Survey Water-Data Report FL-86-1A.

U.S. Geological Survey, 1987, Water resources data for Florida-1986, northeast Florida: U.S. Geological Survey Water-Data Report FL-86-1B.

U.S. Geological Survey, 1987, Water resources data for Florida-1986, south Florida Surface Water: U.S. Geological Survey Water-Data Report FL-862A.

U.S. Geological Survey, 1987, Water resources data for Florida-1986, south Florida Ground Water: U.S. Geological Survey Water-Data Report FL-86$2 B$.

U.S. Geological Survey, 1987, Water resources data for Florida-1986, southwest Florida Surface Water: U.S. Geological Survey Water-Data Report FL-86-3A.

U.S. Geological Survey, 1987, Water resources data for Florida-1986, southwest Florida Ground Water: U.S. Geological Survey Water-Data Report FL$86-3 B$.

U.S. Geological Survey, 1987, Water resources data for Florida-1986, northwest Florida: U.S. Geological Survey Water-Data Report FL-86-4. 
FL-005 QUALITY OF PRECIPITATION

DATE PROJECT BEGAN: July 1983

DATE PROJECT ENDS: Continuing

PRINCIPAL INVESTIGATORS: Terrie M. Lee, Tampa

George A. Irwin, Tallahassee

COOPERATING AGENCY: Federal Program

PROBLEM: The amount of substances dispersed in the atmosphere and deposited by precipitation, aerosols, and bases is expected to continue to increase throughout North America. Thus, there is a need for careful measurement of the amounts, nature, and effects of these substances. Such measurements are essential for responsible management of the agricultural, forest, and aquatic ecosystems of the United States.

OBJECTIVE: The National Atmospheric Deposition Program (NADP) was created to conduct research on atmospheric deposition and its affect on surface waters and agricultural and forest lands in cooperation with federal, state and private research agencies. The U.S. Geological Survey (USGS) is participating in this program under the title of the National Trends Network (NTN) by establishing up to 40 stations nationwide with coordination and analytical services provided by NADP. These stations are established for the purpose of long term coordinated data collection for use in local, regional and national studies.

APPROACH: Basic data atmospheric deposition will be collected at a NADP/NTN approved site (N39). Methods of data collection and instrumentation conform to NADP procedures and guidelines. Data collection will be continuous with weekly sample collections in addition to collecting additional samples for non-standard events. All samples will be shipped to NADP Central Analytical Laboratory (CAL) which is operated by the Illinois State Water Survey.

PROGRESS: Data were collected on a weekly schedule.

PLANS FOR THIS YEAR: The data collection sites will be maintained and operated according to National Atmospheric Deposition Program/ National Trends Network (NADP/NTN) standards and schedule.

REPORTS IN PROCESS: No reports planned for this project; data will be stored in WATSTORE data files. 
DATE PROJECT BEGAN: July 1975

DATE PROJECT ENDS: Continuing

PRINCIPAL INVESTIGATOR: R. Rumenik, District Office, Tallahassee

COOPERATING AGENCIES: Florida Department of Environmental Regulation, Northwest Florida Water Management District, St. Johns River Water Management District, South Florida Water Management District, Southwest Florida Water Management District and Suwannee River Water Management District.

PROBLEM: Florida is undergoing a rapid growth in population and industry. With this growth the competition for water for municipal, rural, industrial, agricultural, and thermoelectric power has become more acute. Although water-use data have been collected every 5 years since 1965 in the State, there is a need to collect the data annually.

OBJECTIVE: The objective of this joint State and Federal effort is to provide a reliable estimate of the annual water use by county, by Water Management Districts (WMDs), and by hydrologic units. This annual evaluation will aid the WMDs in determining water-use trends and in devel ?ing water-use plans and issuing water use permits. Water-use data will be updated annual1y and published every 5 years. Data have been published by state category in a national report since 1950; and for all water-use catejories in State reports since 1965. In addition, much effort will be expended to research methods of improving techniques for data collection and to standardize the storage and retrieval of water-use information. The collection of sitespecific data for use in hydrologic studies will also be intensified.

APPROACH: Collect and compile water-use information annually through the concerted efforts of the U.S. Geological Survey and the State's Water Management Districts from the following sources: public-supply water systems, rural self-supplied domestic and livestock systems, industrial self-supplied systems, irrigation self-supplied systems, and thermoelectric self-suppiied systems. Upgrade the quality of data by minimizing estimated values where actual values are attainable by enhancing methods and procedures for collecting data, and by maintaining all data in an automatic data system. St. Johns River Water Management District serves as the lead agency responsible for the coordination of water-use activities within the State; prior to 1985, USGS served in this capacity.

PROGRESS: The St. Johns River Water Management District (SJRWMD) under a cooperative agreement with the USGS, has coordinated the efforts of all WMD's for the compilation of all categories of the 1985 water-use data for Florida. These data have been stored in computer files on the USGS Prime computer system to be retrieved as part of a National water-use report. Two State reports are in progress: 1) the first draft of the Water-Resources Investigation report has been completed; 2) a map report is in preparation. Research methods were applied for improving techniques for collecting 
(FL-007)

irrigation water-use data in 16 counties in the Southwest Florida Water Management District. Data included total water withdrawn in 1986 and number or irrigated acres by crop type.

PLANS FOR THIS YEAR: Prepare two State reports of estimated water use in 1985. Continue monitoring benchmark farms for total use of ground- and surface-water and number of irrigated acres by crop type for 16 counties in west-central Florida through December 1987. Data will be compiled and presented in a data release to the cooperator.

REPORTS IN PROGRESS:

Marella, R., Water withdrawals and use in Florida, 1985.

\section{REPORTS RELEASED:}

Healy, H. G., Public water supplies of selected municipalities in Florida, 1976: (tables only, open filed).

1977, Public water supplies of selected municipalities in Florida, 1975: U.S. Geological Survey Water-Resources Investigations 77-53.

Leach, S. D., 1977, Water use inventory in Florida, 1975: U.S. Geological Survey Open-File Report 77-577.

1978, Source, use, and disposition of water in Florida, 1975: U.S. Geological Survey Water-Resources Investigations 78-17.

1978, Freshwater use in Florida, 1975: Florida Bureau of Geology Map Series 87.

Duerr, A. D., and Trommer, J. T., 1979, Estimated water use in the Southwest Florida Water Management District, and adjacent areas: U.S. Geological Survey Open-File Report 81-56.

Leach, S. D., and Healy, H. G., 1980, Estimated water use in Florida, 1977: U.S. Geological Survey Water-Resources Investigations 79-112.

Duerr, A. D., and Trommer, J. T., 1981, Estimated water use in the Southwest Florida Water Management District and adjacent area, 1980: U.S. Geological Survey Open-File Report 81-1060.

Leach, S. D., 1982, Estimated water use in Florida, 1980, Florida Bureau of Geology Map Series 103.

Duerr, A. D., and Trommer, J. T., 1983, The benchmark farm program--a method for estimating irrigation water use in southwest Florida: U.S. Geological Survey Water-Resources Investigation 82-17.

Duerr, A D., and Sohm, J. E., 1983, Estimated water use in southwest Florida 1981, and summary of water use, 1970, 1975, and 1977-81: U.S. Geological Survey Open-File Report 83-45.

Leach, S. D., 1983, Consumptive use of freshwater in Florida, 1980: Florida Bureau of Geology Map Series 105.

1983, Source, use and disposition of water in Florida, 1980: U.S. Geological Survey Water-Resources Investigation 82-4090.

Spechler, R. M., 1983, Estimated irrigation water use in Florida, 1980 Florida Bureau of Geology Map Series 106.

Geiger, L. J., 1984, Water-use computer programs for Florida: U.S. Geological Survey Open-File Report 84-442, 91p. 


\section{FL-012 FLOOD ASSESSMENT}

DATE PROJECT BEGAN: JUIY 1964

DATE PROJECT ENDS: Continuing

PRINCIPAL INVESTIGATOR: W. C. Bridges, Tallahassee

COOPERATING AGENCY: Florida Department of Transportation

PROBLEM: Local and state governments, highway designers, planners, and

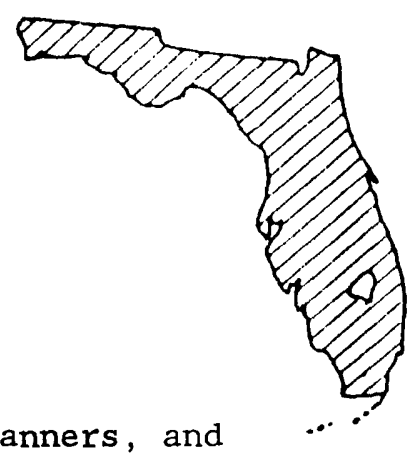
zoning commissions have a responsibility to avoid uneconomic, hazardous or incompatible use and development of the state's flood plains. Prime requisites to meet these criteria are a knowledge of the flood-flow characteris tics of streams and the ability to make reliable estimates of the flood magnitude and frequency.

OBJECTIVE: To assess the hydraulic and hydrologic characteristics of Florida streams. To collect flood flow data and analyze hydraulic problems for selected stream reaches as well as for hydrologic regions. To document and prepare reports for extreme flood events.

APPROACH: Expand the flood peak data base by maintaining a regional network of crest-stage gages. These data will supplement the statewide gaging station network.

Update and maintain the computer files for basin characteristics and peak flow for use in regional flood frequency analysis.

Respond by letter reports to specific requests for hydraulic and hydrologic information for selected stream reaches.

Assess extreme flood events, including indirect flood measurements, analysis, and preparation of reports to disseminate the flood information.

PROGRESS: Work elements continued on the dimensionless hydrograph analysis. An assessment was made of the present flood-crest gaging-station network to define data gaps and future needs. The greatest need is for small basins in the urban areas. At such time that network stations have defined ratings and a minimum of 10 -years record, each site will be discontinued and moved to urban streams.

PLANS FOR THIS YEAR: Assessment of floods and flooding potential will be made on a request basis. Work will continue on hydrograph synthesis-inputing unit discharge and rainfall data for larger basins (30-300 square miles) and developing unit hydrographs. 


\section{REPORTS RELEASED:}

Bridges, W. C., 1972, Effects of Port Orange Bridge-causeway on flow of Halifax River, Volusia County, Florida: U.S. Geological Survey, Florida District, Open-File Report 72-005.

1974, An analysis of 1972-73 floods on Monroe Street and St. Augustine Branch, Tallahassee, Florida: U.S. Geological Survey, Florida District, Open-File Report 74-023.

1982, Technique for estimating magnitude and frequency of floods on natural-flow streams in Florida: U.S. Geological Survey, Florida District, Open-File Report 74-023.

1985, Analysis of water-level fluctuations of the U.S. Highway 90 retention pond, Madison, Florida: U.S. Geological Survey WaterResources Investigations Report 85-4057.

Bridges, W. C., and David, D. R., 1972, Floods of September 20-23, 1969, in the Gadsden County area, Florida: Florida Dept. of Natural Resources, Bureau of Geology Information Circular 79. 
FL-075 FLORIDA WATER ATLAS

DATE PROJECT BEGAN: September 1963

DATE PROJECT ENDS: $\quad$ September 1988

PROJECT COORDINATOR: Walter R. Aucott, Tallahassee

COOPERATING AGENCY: Florida Department of Environmental Regulation

PROBLEM: Water-use planners have repeatedly expressed the need for maps that show the characteristics and availability of water in Florida or that show related information such as climate. Prior to the start of this project only a few maps had been published that give hydrologic data or other data closely related to hydrologic problems in Florida.

OBJECTIVE: This project seeks to make available the needed information in the form of a water atlas--a series of map reports designed to furnish to the user generalized hydrologic, geologic, and related information, portrayed graphically on a standard size map. These maps are most useful for broad planning to aid legislators, planners, industrialists, laymen, and others as well as hydrologists to provide readily available hydrogeologic information for decision making.

APPROACH: Using available information and knowledge from other statewide studies, maps portraying aspects of the hydrologic cycle will be prepared by the U.S. Geological Survey and published by the Florida Geological Survey.

PROGRESS: Five water atlas reports were worked on during the past year. Two were approved, drafted and sent to the publisher. Two were completed and are in the review process.

PLANS FOR THIS YEAR: Publish reports now in review. Begin work on two new atlas reports. Continue work on "Recharge to the surficial aquifers".

\section{REPORTS IN PROCESS:}

Rumenik, R. P., Runoff in hydrologic units in Florida

Aucott, Walter R., Recharge to the Floridan aquifer

Aucott, Walter R., Recharge to the surficial aquifers

Marella, Richard L., Water Use in Florida, 1985

\section{REPORTS RELEASED:}

Healy, H. G., 1962, Piezometric surface of the Floridan aquifer in Florida, July 6-17, 1961: Florida Bureau of Geology Map Series 1.

1962, Piezometric surface and areas of artesian flow of the Floridan aquifer in Florida, July 6-17, 1961; (Revised 1975): Florida Bureau of Geology Map Series 4.

Calver, J. L., 1965, Mineral resources and industries of Florida: Florida Bureau of Geology Map Series 8 .

Shampine, W. J., 1981, Chloride concentration in water from the upper part of the Floridan aquifer in Florida: (Revised 1975), Florida Bureau of Geology Map Series 12. 
REPORTS RELEASED: (Continued)

Shampine, W. J., 1965, Hardness of water from the upper part of the Floridan aquifer in Florida, (Revised 1975): Florida Bureau of Geology Map Series 13.

1965, Dissolved solids in water from the upper part of the Floridan aquifer in Florida, (Revised 1975): Florida Bureau of Geology Map Series 14.

1965, Sulfate concentration in water from the upper part of the Floridan aquifer in Florida; (Revised 1975): Florida Bureau of Geology Map Series 15 .

Hyde, L. W. , 1965, Principal aquifers of Florida; (Revised 1975): Florida Bureau of Geology Map Series 16.

Vernon, R. O., Puri, H. S., 1964, Geologic map of Florida: Florida Bureau of Geology Map Series 18.

Kenner, W. E., 1966, Runoff in Florida: Florida Bureau of Geology Map Series 22.

Kenner, W. E., Pride, R.W., Conover, C.S., 1967, Drainage basins in Florida: Florida Bureau of Geology Map Series 28.

Kenner, W. E., 1969, Seasonal variation of streamflow in Florida: Florida Bureau of Geology Map series 31.

Visher, F. N., Hughes, G.H., 1969, The difference between rainfall and potential evaporation in Florida, (Revised 1975): Florida Bureau of Geology Map Series 32.

Kaufman, M. I., 1969, Generalized distribution and concentration of orthophosphate in Florida streams, (Revised 1975): Florida Bureau of Geology Map Series 33.

Kenner, W. E., Hampton, E. R., Conover, C. S., 1969, Average flow of major streams in Florida, (revised 1975): Florida Bureau of Geology Map Series 34.

Kaufman, M. I., 1969, Color of water in Florida streams and canals: Florida Bureau of Geology Map Series 35 (revised 1975).

Pride, R. W., 1970, Estimated water use in Florida, 1965, (Revised 1975): Florida Bureau of Geology Map Series 36.

Kaufman, M. I., 1970, The $\mathrm{pH}$ of water in Florida streams and canals: Florida Bureau of Geology Map Series 37.

Hughes, G. H., Hampton, E. R., Tucker, D. F., Annual and seasonal rainfall in Florida: Florida Bureau of Geology Map Series 40 (reprinted 1976).

Klein, H., Depth to base of potable water in the Floridan aquifer: Florida Bureau of Geology Map Series 42.

Anderson, W., Temperature of Florida streams: Florida Bureau of Geology Map Series 43.

Vernon, R. 0., 1973, Top of the Floridan artesian aquifer: Florida Bureau of Geology Map Series 56 .

Slack, L. J., Kaufman, M. I., 1973, Special conductance of water in Florida streams and canals, (Revised 1975): Florida Bureau of Geology Map Series 58 .

Hughes, G. H., 1974, Water-level fluctuations of lakes in Florida: Florida Bureau of Geology Map Series 62.

Rosenau, J. C., and Faulkner, G. L., An index to springs of Florida: Florida Bureau of Geology Map Series 63.

stone, R. B., 1974, Low streamflow in Florida-magnitude and frequency: Florida Bureau of Geology Map Series 64. 
(FL-075)

REPORTS RELEASED: (Continued)

Healy, H. G., 1974, The observation-we11 network of the U.S. Geological Survey in Florida: Florida Bureau of Geology Map Series 65.

Sne11, L. J., and Kenner, W. E., 1974, Surface water features of Florida: Florida Bureau of Geology Map Series 66.

Pascale, C. A., Estimated yield of fresh-water wells in Florida: Florida Bureau of Geology Map Series 70.

Healy, H. G., 1975, Terraces and shorelines of Florida: Florida Bureau of Geology Map Series 71.

Conover, C. S., and Leach, S. D., 1975, River basin and hydrologic unit map of Florida: Florida Bureau of Geology Map Series 72.

Healy, H. G., 1975, Potentiometric surface and areas of artesian flow of the Floridan aquifer in Florida, May 1974: Florida Bureau of Geology Map Series 73.

Causey, L. V., Leve, G. W., 1976, Thickness of the potable-water zone in the Floridan aquifer, Florida Bureau of Geology Map Series 74.

Slack, L. J., Goolsby, D. A., 1976, Nitrogen loads and concentrations in Florida streams: Florida Bureau of Geology Map Series 75.

Slack, L. J., 1977, Program for monitoring surface-water quality in Florida: Florida Bureau of Geology Map Series 76.

Dysart, J. E., Goolsby, D. A., 1977, Dissolved-solids concentrations and loads in Florida surface waters: Florida Bureau of Geology Map Series 77.

Dysart, J. E., 1978, Satellite image mosaic NASA ERTS-1 imagery-1973: U.S. Geological Survey Misc. Invest. Maps.

Hughes, G. H., 1978, Runoff from hydrologic units in Florida: Florida Bureau of Geology Map Series 81 .

Phelps, G. G., 1978, Chemical quality of water used for municipal supply in Florida, 1975, Florida Bureau of Geology Map Series 82.

1978, Principal uses of freshwater in Florida, 1975: Florida Bureau of Geology Map Series 83.

Leach, S. D., 1978, Freshwater use in Florida, 1975: Florida Bureau of Geology Map Series 87.

Hul1, R. W., Irwin, G. A., 1979, Quality of untreated water for public supplies in Florida with reference to the National Primary Drinking Water Regulations: Florida Bureau of Geology Map Series 91.

Miller, J. A., 1979, Potential subsurface zones for liquid waste storage in Florida: Florida Bureau of Geology Map Series 94.

Slack, L. J., Rosenau, J. C., 1979, Water quality of Florida springs: Florida Bureau of Geology Map Series 96.

Stewart, J. W., 1980, Areas of natural recharge to the Floridan aquifer in Florida: Florida Bureau of Geology Map Series 98.

Healy, H. G., 1981, Estimated pumpage from ground-water sources for public supply and rural domestic use in Florida, 1977: Florida Bureau of Geology Map Series 102.

Leach, S. D., 1982, Water use in Florida, 1980: Florida Bureau of Geology Map Series 103.

Healy, H. G., 1982, Potentiometric surface of the Floridan aquifer, May 1980: Florida Bureau of Geology, Map Series 104.

Leach, S. D., 1982, Consumptive water use in Florida, 1980: Florida Bureau of Geology Map Series 105. 
(FL-075)

REPORTS RELEASED: (Continued)

Spechler, R. M., 1983, Estimated Irrigation water use in Florida, 1980: Bureau of Geology Map Series 106.

Foose, D. W. and Sohm, J. E., 1983, An index to long term surface water sites in Florida: Florida Bureau of Geology Map Series 107.

Leach, S. D., 1984, Projected public supply and rural (self-supplied) water use in Florida through year 2020: Florida Bureau of Geology Map Series 108.

Hampson, P. S., 1984, Wetlands in Florida: Florida Bureau of Geology Map Series 109.

Sinclair, W. C. and Stewart, J. W., 1985, Sinkhole type, development, and distribution in Florida: Florida Bureau of Geology Map Series 110. 
DATE PROJECT BEGAN: October 1970

DATE PROJECT ENDS: Continuing

PRINCIPAL INVESTIGATOR: J. J. Hickey, Tampa

\section{COOPERATING AGENCY: Federal Program}

PROBLEM: Liquid wastes are now being injected into saline water in the deeper zones of the Floridan aquifer with indication of expanded use of the aquifer waste-storage capacity, especially in regard to storing-disposing of secondary treated sewage effluent. The hydrologic and geochemical characteristics are not adequately known to effectively evaluate the potentialities and possible consequences of subsurface waste storage. Based on the present state of knowledge, reliable prediction of the movement, chemical interactions, and ultimate fate of liquid wastes underground is uncertain.

OBJECTIVE: To provide the needed scientific information base and guidelines for a comprehensive evaluation of the lithology, hydrology and geochemistry of the deep saline parts of the aquifer systems, and for planning-management decisions among a multiplicity of possible uses of the saline aquifers, including subsurface liquid waste storage. The investigation is coordinated with the geologic research phase being conducted by the Florida Bureau of Geology.

APPROACH: Assessment and synthesis of available hydrologic and geochemical data into a regional appraisal of the deep saline-water part of the aquifer system; inventory, assessment and evaluation of active and planned subsurface waste disposal systems in Florida, compilation of data, field investigations, and preparation of summary report including case studies, and establishment of a foundation for expanded effort in subsequent years via liaison with regulatory agencies, consultants, companies, the Florida Bureau of Geology and WRD research personnel.

PROGRESS: Two reports and one abstract were approved for publication by the Director. One of the reports was presented at an international symposium and was published in its' proceedings. The principal investigator was selected to be a member of the Science Advisory Committee of the Underground Injection Practices Council. A contributing member of the project was asked to plan a symposium on subsurface injection for the 1988 American Geophysical Union (AGU) spring meeting.

PLANS FOR THIS YEAR: Guide variable-salinity report through the approval process. Continue work on study dealing with physical factors that influence circular convection during subsurface injection. Start a study about the hydrogeology of injection zones and associated confining units in the Floridan aquifer system of Peninsula Florida. 
REPORTS IN PROCESS:

Hickey, J. J., Some physical factors that influence circular convection during subsurface injection.

Hickey, J. J., An approach to the field study of hydraulic gradients in variable salinity ground-water flow; Journal Article.

\section{REPORTS RELEASED:}

Kaufman, M. I., 1973, Subsurface wastewater infection, Florida: Amer. Soc. Civil Engineers, Proc. Paper 9598, vol. 99, no. IRI, p. 53-70.

Goolsby, D. A., 1972, Geochemical effects and movement of injected indus. trial waste in limestone aquifer: Amer. Assoc. Petroleum Geologists Memoir 18, p. 355-368.

Kaufman, M. I., Goolsby, D. A., and Faulkner, G. L., 1973, Injection of acidic industrial waste into a saline carbonate aquifer: Geochemical aspects: Amer. Assoc. Petroleum Geologists, Underground Waste Management and Artificial Recharge, vol. 1, p. 526-551.

Wilson, W. E., Rosenshein, J. S., and Hunn, J. D., 1973, Hydrologic evaluation of industrial waste injection at Mulberry, Florida: Amer. Assoc. Petroleum Geologists, Underground Waste Management and Artificial Recharge, vol. 1, p. 552-564.

Puri, H. S., Faulkner, G. L., and Winston, G. 0., 1973, Hydrogeology of subsurface liquid waste storage in Florida: Amer. Assoc. Petroleum Geologists, Underground Waste Management and Artificial Recharge, vol. 2, p. $825-850$.

Meyer, F. W., 1974, Evaluation of hydraulic characteristics of a deep artesian aquifer from natural water-level fluctuations, Miami, Florida: Florida Bur. of Geology, Rept. of Inv. No. 75, 32 p.

Faulkner, G. L., and Pascale, C: A., 1975, Monitoring regional effects of pressure injection of wastewater in a limestone aquifer: Ground Water, Vo1. 13, No. 2, p. 197-208.

Kaufman, M. I., and McKenzle, D. J., 1975, Upward migration of deep-well waste-injection fluids in Floridan aquifer, south Florida: U.S. Geological Survey Journal Research, Vo1. 3, No. 3, 261-271.

Pascale, C. A., 1976, Construction and testing of two waste-injection monitor wells in northwest Florida: U.S. Geological Survey Open-File Rept. 76-1, 42 p.

Pitt, W. A., Jr., and Meyer, F. W., 1976, Ground-water quality at the site of a proposed deep-well injection system for treated waste-water, West Palm Beach, Florida: U.S. Geological Survey Open-File Rept. 76-91, 43 p.

McKenzie, D. J., 1976, Injection of acidic industrial waste into the Floridan aquifer near Belle Glade, Florida: Upward migration and geochemical interaction 1973-75: U.S. Geological Survey Open-File Rept.76$626,54 \mathrm{p}$.

Wilson, W. E., 1976, Hydrologic data for a subsurface waste-injection site at Mulberry, Florida 1972-75: U.S. Geological Survey Open-File Rept. 76$721,24 \mathrm{p}$.

Pascale, C. A., and Martin, J. B., 1977, Hydrologic monitoring of a waste injection well near Milton, Florida: U.S. Geological Survey Open-File Rept. 77-368, 46 p.

Wilson, W. E., 1977, Hydrologic data for a subsurface waste injection site, Mulberry, Florida, 1972-76: U.S. Geological Survey Open-File Rept. $77-$ $511,24 \mathrm{p}$. 
REPORTS RELEASED: (Continued)

Pitt, W. H., Meyer, F. W., and Hull, J. E., 1977, Disposal of salt-water during well construction: Problems and solutions: Ground-water, vo1. 15, no. 4, p. $276-283$.

Pascale, C. A., and Martin, J. B., 1978, Hydrologic monitoring of a deepwel1 waste injection system near Pensacola, Florida, March 1970-March 1977: U.S. Geological Survey Water Resources Inv. 78-27, 61 p.

Beaven, T. R., and Meyer, F. W., 1978, Well inventory and data summary for the Floridan aquifer system in Dade and Monroe Counties: U.S. Geological Survey Open-File Rept. OF 78-881, 26 p.

Ehrlich, G. G., Godsy, E. M., Pascale, C. A., and Vecchioli, John, 1979 Chemical changes in an industrial waste liquid during post-injection movement in a limestone aquifer: Pensacola, Florida, Ground Water, vol. 17 , no. 6, p. 562-573.

Vecchioli, John, 1979, Monitoring of subsurface injection of wastes, Florida: Ground Water, vo1. 17, no. 3, p. 244-249.

Miller, J. A., 1979, Potential subsurface zones for liquid-waste storage in Florida: Florida Bureau of Geology, Map Series 94, 1 sheet.

Meyer, F. W., 1980, Disposal of liquid wastes in cavernous dolomites beneath southeastern Florida: Proceedings of the International Association of Hydrogeologists.

Vecchioli, John, Ehrlich, G. G., Godsy, E. M., and Pascale, C. A., 1980, Alterations in the chemistry of an industrial waste liquid injected into limestone near Pensacola, Florida: Proceedings of the International Association of Hydrogeologists.

Vecchioli, John, 1981, Subsurface injection of liquid waste in Florida, United States of America: Proceedings of the International Symposium on Ground-Water Quality, March 23-27, 1981.

Hickey, J. J., 1981, Hydrogeology, estimated impact, and regional well monitoring of effects of subsurface wastewater injection, Tampa Bay area, Florida: U.S. Geological Survey Water Resources Investigations 80118 .

Hickey, J. J. and Vecchioli, J., 1981, Subsurface injection of 1iquid waste with emphasis on injection practices in Florida, U.S. Geological Survey Water Supply Paper 2281.

Hickey, J. J., and Wilson, W. E., 1982, Results of deep-well injection testing at Mulberry, Florida: U.S. Geological Survey Water-Resources Investigations $81-75,15 \mathrm{p}$.

Hull, R. W., and Martin, J. B., 1982, Data on subsurface storage of liquid waste near Pensacola,, Florida, 1963-1980: U.S. Geological Survey OpenFile Report 82-689, 179 p.

Hickey, J. J., 1982, Hydrogeology and results of injection tests at wasteinjection test sites in Pinellas County, Florida: U.S. Geological Survey Water-Supply Paper 2183, 42 p.

Schiner, G. R., and German, E. R., 1983, Effects of drainage well recharge on quality of water of the Floridan aquifer in the Orlando area, central Florida: U.S. Geological Survey Water Resources Investigations Report 82-4094, p. 124.

Hickey, J. J., 1984, Subsurface injection of treated sewage into a salinewater aquifer--aquifer pressure buildup: Ground Water, v. 22, no. 1, p. $48-55$. 
REPORTS RELEASED: (Continued)

Hickey, J. J., and Ehrlich, G. G., 1984, Subsurface injection of treated sewage into a saline-water aquifer--water quality changes and potential for recovery of injected sewage: Ground Water, v. 22, no. 4, p. 397-405.

Hickey, J. J., 1984, Field testing the hypothesis of Darcian flow through a carbonate aquifer: Ground Water, v. 22, no. 5, p. 544-547.

Kimrey, J. O., and Fayard, L. D., 1984, Geohydrologic reconnaissance of drainage wells in Florida--an interim report: U.S. Geological Survey Water Resources Investigations Report 84-4021, $67 \mathrm{p}$.

McKenzie, P. J., and Irwin, G. A., 1984, Quality of water recovered from a municipal effluent injection well in the Floridan aquifer system, Pompano Beach, Florida: U.S. Geological Survey Water Resources Investigations Report 84-4100, 23 p.

Merritt, M. L., 1984, Digital simulation of the regional effects of subsurface injection of liquid waste near Pensacola, Florida: U.S. Geological Survey Water-Resources Investigations Report 84-4042, $73 \mathrm{p}$.

Hickey, J. J., 1986, Saltwater circulation during subsurface injection of liquid waste, St. Petersburg, Florida (Journal Article).

Hickey, J. J., 1986, Saltwater circulation during subsurface injection (Abstract). 
FL-362 EVALUATION OF STORMWATER DETENTION BASINS IN WEST-CENTRAL FLORIDA

DATE PROJECT BEGAN: October 1980

DATE PROJECT ENDS: September 1990

PRINCIPAL INVESTIGATOR: Migue1 A. Lopez, Tampa

COOPERATING AGENCY: Pine11as County

PROBLEM: Pinellas County is one of the most densely populated counties in Florida, and serious water quality problems in the Gulf of Mexico and Tampa Bay are caused by the increase in urban runoff. There is a need for data to evaluate the cost-effectiveness of the pollution control measures being planned to satisfy receiving water quality standards.

OBJECTIVE: To determine the effectiveness of runoff detention ponds in reducing suspended solids, nutrients, metals, BOD, and coliform loading entering receiving waters from urban areas in Pinellas County.

APPROACH: Runoff quantity and quality of an urban watershed will be monitored for a year before the construction of a stormwater detention pond just upstream from the monitoring station. This will provide background information to compare with data after the completion of the pond in the second year. After completion of the pond, an additional monitoring station will be operated at the inflow. Loads entering and leaving the pond will be compared. An interpretive report will be written in the third year after at least one complete year of inflow and outflow data have been analyzed.

PROGRESS: Daily inflow and outflow was recorded for the Alligator Creek detention basin. Quarterly base flow samples were collected at each site. Storm runoff water quality samples were collected and storm loads computed for two storms. All data collection at the Alligator Creek stations were discontinued at the end of the year because the cooperator's funding was curtailed. Daily discharge was recorded at the inflow and outflow of a proposed detention basin on Saint Joes Creek. Six storms were sampled.

PLANS FOR THIS YEAR: Continue to operate the outflow station on Saint Joes Creek. Record daily discharge and rainfall. Collect quarterly base flow quality samples. Collect storm runoff quality samples and compute constituent loads of total solids, nitrogen, phosphorus, chloride, lead, zinc, chromium, and copper for six storms. 
FL-377 ENVIRONRGMTIAL ASSESSYGENT STUDY OF THE CHARLOTTE HARBOR ESTUARINE SYSTEM AND SURROUNDING AREA, SOUTHWEST FLORIDA

DATE PROJECT BEGAN: July 1982

DATE PROJECT ENDS: June 1989

PRINCIPAL INVESTIGATOR: B. F. McPherson, Tampa

COOPERATING AGENCY: Florida Department of Environmental Regulation

PROBLEM: The area surrounding the Charlotte Harbor estuarine system is undergoing rapid development and population growth. As development occurs, surface-drainage features will be modified, and area water resources will undergo increased stress from water-supply withdrawals and waste disposal. Consequently, the magnitude of freshwater inflow to the estuarine system will be reduced and the inflow patterns altered. Saltwater may move upstream on principal tributarles and into surficlal and intermediate aquifer systems, and sallnity in the estuarine system may increase. Altered inflow patterns and increased chemical constituent loads will affect physical, chemical, and biological processes in the estuarine system.

OBJECTIVE: To determine existing conditions and evaluate the impact of future development on water-related resources of the Charlotte Harbor estuary. Specific objectives are to evaluate: (1) Freshwater runoff in the major tributaries and salinity distribution in the estuary. (2) Land and water use in the basin. (3) Material transport and water-quality characteristics in the major tributaries. (4) Circulation, flushing, and transport characteristics of the estuarine system. (5) Water-quality characteristics of the estuarine system, including physical, optical, chemical, radiochemical, and biological properties. (6) Relationships between freshwater runoff, nutrient loading, and water-quality characteristics in the estuarine system.

APPROACH: Information will be gathered from the existing literature and from field data collected to define and describe the estuarine system so as to meet the objectives 1isted above. Available information includes - (1) numerous scientific and technical reports, maps, etc.; and (2) rainfall, temperature, streamflow, water-quality, stream channel cross-sections, tide stage and velocity, water-use, land-use, and topographic data. However, much additional biologic and hydrologic data will be required to meet study objectives. Evaluation will require application of varlous engineering and hydrologic methods including digital models that simulate hydraulic and water-quality conditions in streams and estuaries.

PROGRESS: Data were collected in 1987 to help confirm and calibrate the hydrodynamic model. A series of overflights were made in April to photographically trail and document the intrusion of turbid Gulf of Mexico water into the clean water within the harbor. Additional tide gage stage data were collected synoptically throughout the harbor and at three gages installed in the Gulf. Work continued on the collection of water-quality and phytoplankton biomass and productivity data. Monthly sampling continued at four locations to document phytoplankton productivity and to provide information that will be used to relate productivity to water quality, 
(FL-377)

salinity, freshwater runoff and light penetration. Compilation and analysis of hydrodynamic, chemical, and biological data continued along with preparation of reports.

PLANS FOR THIS YEAR: Additional water-quality field trips are planned to gather information on light atttenuation and phytoplankton productivity, and to measure salinity distribution following heavy runoff. Work will continue on data compilation, analysis, and interpretation and on preparation of reports.

\section{REPORTS IN PROCESS:}

Miller, R. L., McPherson, B. F., and Kraemer, Origin of ${ }^{228} \mathrm{Ra},{ }^{226} \mathrm{Ra}$ and $222 \mathrm{Rn}$ in Charlotte Harbor estuary, Florida, with estimates of groundwater inflow using ${ }^{26} \mathrm{Ra}$ and salinity data.

Stoker, Y. E., Henderson, S.E., and McPherson, B. F., Hydraulic and salinity characteristics of the Tidal Peace River, southwestern Florida.

Stoker, Y. E., Phytoplankton composition and abundance and relation to environmental parameters in the Charlotte Harbor estuarine system, southwestern Florida.

\section{REPORTS RELEASED:}

Stoker, Yvonne E. and Karavitis, George A., 1983, Literature assessment of the Charlotte Harbor Estuarine System and surrounding area, southwest Florida.

Stoker, Yvonne E., 1985, Water quality of the Charlotte Harbor estuarine system, November 1982 through October 1984. Open-file report.

Estevez, E. D., 1985, Infauna1 macroinvertebrates of the Charlotte Harbor estuarine system and surrounding inshore waters, Florida: Water Resources Investigation Report 85-4260.

Fraser, T. H., 1986, Long-term water-quality characteristics of Charlotte Harbor, Florida: Water Resources Investigations Report 86-4180.

McPherson, B. F. and Miller, R. L., 1986, The vertical attenuation of light in Charlotte Harbor, a shallow, subtropical estuary, southwestern Florida (Journal Article).

Hammett, K. M., Landuse, water use, and hydrologic characteristics of the Charlotte Harbor inflow area, Florida: Open-File Report OFR 87-472. 


\section{FL-393 FLOW CHARACTERISTICS OF MASSAU RIVER BASIN AND ESTUARY}

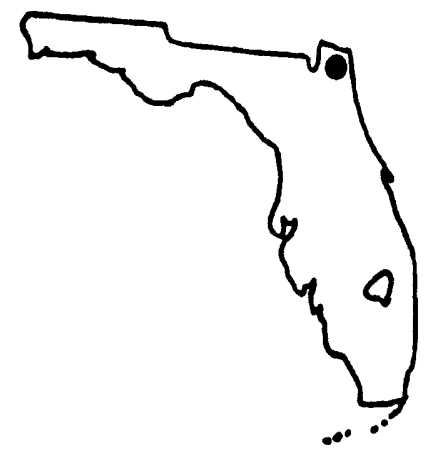

COOPERATING AGENCY: St. Johns River Water Management District

PROBLEY: To evaluate the Impact of future development in the Nassau River Basin, basic hydrologic data are needed. Modifications to biological systems may occur because of changes in salinity distributions. These modifications could have long-term, detrimental effects on the ecological balance of estuarine systems. To properly manage and conserve freshwater resources and to maintain an ecological balance, an understanding of the relation between saltwater movement and freshwater inflow to estuaries is needed. Specifically needed are cor inuous records of discharge, volume, direction of flow, velocity, water emperature, specific conductance, dissolved oxygen, and $\mathrm{pH}$.

OBJECTIVE: The possibility of making laximum use of the land and water areas without upsetting the ecologi al balance hinges upon sufficient knowledge of the system. This stud. will provide information on the surface-water movement and water q ality in the Nassau Estuary. The comprehensive information gained $\mathrm{fr} m$ the study will afford us the opportunity to begin to understand we processes of work in an estuary system. Most importantly this baseline knowledge can be transferred to neighboring estuaries.

APPROACH: The first phase is a basin reconnaissance, temporary gage installation, data collection and evaluation. Phase two includes equipment installation, basic data collection and evaluation, development and calibration of a one-dimensional flow model, and preparation of an interpretive report.

PROGRESS: During FY86, stage data were collected at six stations, discharge data were collected at three stations, rainfall data were collected at four stations and velocity, temperature, and conductance data were collected at two stations in the Nassau Basin. A velocity probe was also installed at Mills Creek near Italia.

PLANS FOR THIS YEAR: Data collection will continue during FY88, testing of the Branch Model will continue and the final report describing the flow model will be completed. 
FL-406 OCCURRENCE, MOVEMENT, AND FATE OF ORGANIC CONTAMINANTS

IN GROUND WATER NEAR PENSACOLA, FLORIDA

DATE PROJECT BEGAN: October 1986

DATE PROJECT ENDS: September 1989

PRINCIPAL INVESTIGATOR: Walter R. Aucott, Tallahassee

COOPERATING AGENCY: Federal

PROBLEM: American Creosote Works, Inc. (ACW), located in northwest Florida within the city limits of Pensacola, presents an opportunity to investigate the biodegradation of hazardous wastes and the feasibility of enhancement of aquifer restoration processes under one set of hydrogeologic conditions. During the 70 years of continuous operation, wastewaters generated from the use of creosote and PCP in the wood-treatment process were discharged into two unlined surface impoundments which are in direct contact with the sandand-gravel aquifer, the principal source of water in western panhandle Florida.

OBJECTIVE: (1) To define the chemical constituents in the subsurface and the extent of contaminant movement in the aquifer. (2) To study processes involved in the degradation of organic compounds. (3) To investigate impacts of organic contaminants on the nearshore environments in Pensacola Bay. (4) To continue field testing of analytical methods useful in defining organic contamination in ground water.

APPROACH: (1) Continue data collection from wells in the monitoring network. (2) Publish. (3) Continue field studies of analytical methods useful in plume delineation. (4) Continue coordination of concurrent multidisciplinary research efforts concerned with geochemical and microbial processes affecting contaminant distribution and movement. (5) Complete introductory chapter in series summarizing research results.

PROGRESS: The report documenting the hydrogeology of the contaminated site using 3-D finite-difference ground-water flow model was approved and is now in final drafting. Field support was provided for continuing NRP research efforts. The Third Annual GW Toxic Waste Meeting in Pensacola, March, 1987 was coordinated. Investigation of clay minerology at sand-clay interfaces was begun.

PLANS FOR THIS YEAR: Field support for NRP research efforts has been completed. The introductory chapter of a Water Supply Paper series summarizing research results at the site will be written and reviewed. Work will continue on the clay minerology.

REPORTS IN PROCESS:

Franks, B. J., 1986, Evaluation of a sand-and-gravel aquifer contaminated by wood-preserving compounds, Pensacola, Florida--Part I, Hydrogeology: USGS Prof. Paper (in review). 
(FL-406)

\section{REPORTS RETEASED:}

Franks, B. J., Goerlitz, D. F., and Baedecker, M. J., 1985, Defining a contaminant plume using on-site analytical techniques in Petroleum hydrocarbons and organic chemicals in ground water: Prevention, detection, restoration: Second Annual Conference, November 1985, Houston, Texas), P. 265-275.

Goerlitz, D. F., Troutman, D. E., Godsy, E. M., and Franks, B. J., 1985, Migration of wood-preserving chemicals in contaminated groundwater in a sand aquifer at Pensacola, Florida: Environmental Science and Technology, v.19, no. 10, p. 955-961.

Kantrowitz, I. H., Field methods for studying contaminated ground water: A U.S. Geological Survey perspective: ASTM Special Technical Publication.

Mattraw, H. C. Jr., and Franks, B. J., editors, 1986, Movement and fate of creosote waste in ground water, Pensacola, Florida: U.S. Geological Survey toxic waste ground-water contaminated program: U.S. Geological Survey Water-Supply Paper 2285, Chapters A-I, 63 p.

Ragone, S. E., 1986, U.S. Geological Survey Toxic Waste--Ground-Water Contamination Program, Fiscal Year 1986. Program overview and selected abstracts presented at the Toxic Waste Program Technical meeting: Cape Code, Mass., October 1985: U.S. Geological Survey Open-File Report 86 481 . 
DATE PROJECT BEGAN: October 1983

DATE PROJECT ENDS: Continuing

PRINCIPAL INVESTIGATOR: C. H. Tibbals, Orlando

COOPERATING AGENCIES: South Florida Water Management District, Southwest Florida Water Management District, St. Johns River Water Management District, and Suwannee River Water Management District

PROBLEM: From 1950 to 1980, the population of Florida grew from about 2.8 million to about $9.8 \mathrm{million}$, an increase of 350 percent. By 2000 , the population is expected to grow to about 17 million. Population growth, plus that of industry and the increased use of ground water for crop irrigation has placed great demand on the ground-water resource. The principal source of fresh ground water is the Floridan aquifer system which underlies all of Florida and parts of Alabama, Georgia, and South Carolina. The effects of increased pumping of ground water have been responsible, in part, for lower pressure heads in the Floridan which, in turn, are responsible for intrusion of salty water along both the east and west coasts of peninsular Florida and along the Gulf coast of north-central Florida; lower lake levels; lower water levels in the surficial aquifer; reduced streamflow; and, to some degree, increased potential for sinkhole activity.

OBJECTIVE: The overall objective is to provide the basis for long-term liaison and, thus, coordination between the U.S. Geological Survey (USGS) and the five State Water Management Districts as regards refinement and uses of the regional and subregional Floridan aquifer computer models constructed during the now-completed Floridan Regional Aquifer Systems Analysis (RASA) projects; to provide information on new modeling techniques; and to provide, on an as-needed basis, general guidance and advice on matters that relate to ground-water modeling in general and ground-water hydraulics. Other, more specific, objectives are: (1) Identify data and investigate needs on an areal basis; (2) Suggest and help implement changes to existing models; (3) Help provide results of specific-purpose modeling runs done in cooperation with the Southeastern Region staff that maintains the regional model; (4) Participate in the development of a high resolution (small grid block), multi-District ground-water model data base; (5) Develop techniques to access that data base at any location so as to provide "moveable models," small models for any area that are, for the most part, already calibrated and that can be quickly constructed.

APPROACH: Liaison and coordination will be accomplished by means of both formal and informal meetings and discussions between the USGS District project leader, the Water Management District staffs, and the USGS Southeast Regional staff. Data and investigative needs will be assessed on a continuing basis by the USGS and the Water Management District staffs as the Districts implement their respective water-management plans. Some of these needs will be identified as the USGS regional RASA model is called upon to furnish results of specific purpose modeling runs to determine various 
(FL-410)

stress-effect relations. The high-resolution data base will be constructed by adapting and incorporating the data bases generated for the regional and subregional models. The USGS Trescott-Larson three-dimensional source code will be the first to be modified to access the data base. Later, the USGS McDonald-Harbaugh three-dimensional modular model will be modified. Programs will be written in Fortran 77 to be executed in interactive mode.

PROGRESS: The "Moveable model" is operational for use with either the modified McDonald-Harbaugh modular model or the modified Trescott-Larson model. Digitize/discretize programs under development for input of thematic map data. Color 3-D graphics interface was developed for model output and is available for use by Water Resources Division (WRD) personnel via netlink.

PLANS FOR THIS YEAR: Continue to refine "Moveable Model". Complete digitize/discretize input programs. Input historical potentiometric maps to master database.

REPORTS IN PROCESS:

Rutledge, A.T., A program for converting rectangular coordinates to latitude-longitude coordinates. 


\section{FL-412 SIMULATION APPROACHES TO UNDERSTANDING GROUND-WATER SURFACE-WATER RELATIONSHIPS AND WATER BUDGETS IN FLORIDA LARES}

DATE PROJECT BEGAN: October 1983

DATE PROJECT ENDS: September 1988

PRINCIPAL INVESTIGATOR: Terrie M. Lee, Tampa

COOPERATING AGENCY: Southwest Florida Water Management District

PROBLEM: Water managers' responsibility to administer all water resources is hampered by multi-water use from residential and recreational use of surface water to agricultural-municipal-industrial use of water. With a mandate for equitable allocation of water resources, water managers need quantitative information that indicates the relationship between the lakessurficial aquifers and the Floridan aquifer to manage the public resource.

OBJECTIVE: (1) To define the influence of head in the Floridan aquifer on lake levels. (2) To gain a better understanding of the recharge process in the surficial aquifer. (3) To provide an accurate determination of evaporation and evaporation processes. (4) To provide a realistic water budget with error estimates for Lake Lucerne.

APPROACH: In cooperation with the National Research Program (NRP) Lake Hydrology Project headed by T.C. Winter, a detailed ground water-surface water-atmospheric-water relationship will be studied. Methods of analysis will include two-dimensional digital modeling of the lake-ground water system in cross-section for steady state and transient flow, and, depending upon results of the two-dimensional model, a three-dimensional model may be applied. The applicability of saturated-unsaturated model will be evaluated for future work. Evaporation will be calculated using energy budget techniques and compared to methods more generally used such as pan and mass transfer methods. The study of wind and vapor pressure profiles over the lake will also be studied as they relate to the evaporation process. Determination of the surface water component of the water budget is limited to overland flow and processes in this closed basin lake.

PROGRESS: The baseline report (WRI) describing the extensive hydrologic and geologic database from lake Lucerne was written and is in review. The report contains 51 figures including period of record plots of the daily average values of meteorological variables to be used in evaporation computations. A considerable amount of time was required during the year to manipulate the continuous-record climatic database in preparation for use in the evaporation models. Computing lake evaporation by the energy-budget and mass-transfer methods will be the first attempted in Florida. The lakegroundwater analyses completed this year includes flow-net analyses of groundwater inflow and lake leakance, and numerical simulation of the vertical head distribution around Lake Lucerne under observed and hypothetical levels of potentiometric head in the Floridan aquifer. Lake Lucerne and the adjacent surficial aquifer naturally recharges the underlying Upper 
(FL412)

Floridan aquifer. Superimposed on this natural lake leakance is a seasonally induced leakance caused by local pumpage. The downward head gradients which result induce the greatest leakance from areas of the lakebed which overlie the columnar solution features in the limestone Upper Floridan aquifer. Preparation of the final interpretive report began the last quarter of FY87. A one-year extension to the scheduled project deadline was approved by the project cooperator.

PLANS FOR THIS YEAR: The majority of FY88 will be devoted to the preparation and review of the second project report (WSP). This report describes the water budget of Lake Lucerne and includes energy-budget and mass transfer analyses of evaporation, and an extensive analys is of lake/groundwater interactions. The manuscript for the first project report (WRI) will be revised and final illustrations drafted.

\section{REPORTS IN PROCESS:}

Adams, D. B., Lee, T. M., T ihansky, A. B., and Swancar, Amy, Hydrology setting of Lake Lucerne, Polk County, Florida. 
FL-415 ASSESSMENT OF HYDROGEOLOGICAL CONDITIONS AND ALTERNATIVES FOR SAFEGUARDING WATER QUALITY IN SOUTHWEST SARASOTA COUNTY, FLORIDA

DATE PROJECT BEGAN: October 1983

DATE PROJECT ENDS: $\quad$ September 1988

PRINCIPAL INVESTIGATOR: C. B. Hutchinson, Tampa

COOPERATING AGENCY: Southwest Florida Water Management District

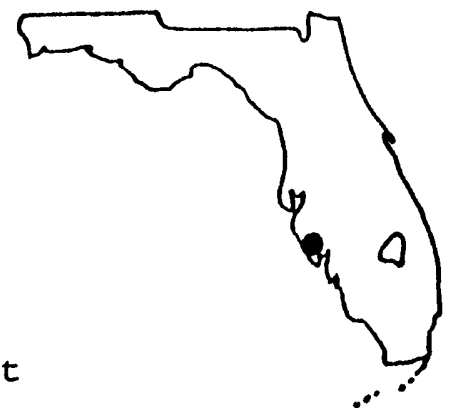

PROBLEM: An assessment needs to be made of hydrogeologic conditions and measures that might be employed to maintain or improve water quality in southwest Sarasota County. Problems to be addressed include determining aquifer parameters and water quality, describing the ground-water flow system, and constructing digital models of ground-water flow and solute transport. The models will be used to better understand historical and future changes in water levels and quality due to expanding pumpage for municipal supply, an ongoing program to identify and plug or repair improperly constructed wells, the movement and dispersion of liquid waste injected into the Floridan aquifer.

OBJECTIVE: (1) To determine aquifer hydraulic parameters and water quality; (2) To provide a description of the ground-water flow system including effects of pumping, injection and circulation between zones; and (3) To use digital models experimentally to understand the flow system and the transport of chemical constituents.

APPROACH: The hydrogeologic system will be conceptualized using available and field-collected data. This conceptual model will form the basis for digital models of ground-water flow and solute transport. The models will increase the understanding of ground-water movement and transport of a single water-quality constituent in the complex hydrogeologic system. They will be applied to simulate: (1) hydrogeologic conditions under various rates of wastewater injection; and (2) lateral and vertical movement of injected sewage effluent and brine from reverse-osmosis facilities.

PROGRESS: Continuous water-level recorders were maintained on nine wells at ROMP sites TR3-1 and TR5-2. Four wells at ROMP TR3-3 were instrumented with submersible pressure transducers during an experimental pumping test of the Suwannee permeable zone within the upper Floridan aquifer. Pressure changes in piezometers above and below the producing zone were recorded, verified by taped measurements, and processed by computer to display water-level hydrographs. Conculusions from the test are that the apparent trans missivity of the Suwannee permeable zone is 20,000 square feet per day, there is good connection between the upper Floridan and lower Hawthorn-upper Tampa aquifers, and using pressure transducers is an effective and reliable method for obtaining water-level data. 
PLANS FOR THIS YEAR: During FY88 experimental modeling will be resumed to assess transport of wastewater injected through typical deep wells in Sarasota and Charlotte Counties. The model will be used to demonstrate pressure build-up in the injection zone, positions of injectant/native water fronts at specific time intervals, travel time of the injectant to overlying potable-water zones, and comparison between injecting reverse-osmosis reject water and sewage effluent. A report summarizing all aspects of the study will be prepared and submitted for review.

REPORTS IN PROCESS:

Hutchinson, C. B., Assessment of geohydrologic conditions with emphasis on water-quality issues in southwest Sarasota and west Charlotte Counties, Florida

Hutchinson, C. B., and Trommer, J. T., Model analysis of hydraulic properties of a leaky aquifer system, Sarasota County, Florida. 
FL-422 IMPACTS OF SELECTED DEVELOPMENTAL ACTIVITIES ON THE QUALITY OF GROUND WATER, CENTRAL FLORIDA

DATE PROJECT BEGAN: April 1984

DATE PROJECT ENDS: September 1990

PRINCIPAL INVESTIGATOR: Edward R. German, Orlando

COOPERATING AGENCY: Federal Program

PROBLEM: There is a need to appraise the quality of ground water in relation to major developmental activities prevalent in recharge areas of the Floridan aquifer system. Many studies have dealt with ground-water quality, although most have not emphasized organic chemicals or trace metals. The three developmental activities of concern are: (1) use of drainage wells for stormwater disposal in urban areas, (2) use of pesticides and fertilizers in citrus groves, and (3) use of various chemicals in processing of phosphate ore and use of interconnector wells for drainage in phosphate mining areas.

OBJECTIVES: Determine the impact of citrus growing, phosphate mining, and urban storm water disposal on ground-water quality. Test the transferability of findings to other areas of similar land use and hydrology. Determine surface loadings of potential contaminants and evaluate conta inant potentials based on chemical properties and transport models. Determine vertical patterns of flow and quality in the surficial aquifer underlying the citrus area.

APPROACH: Design and install a network of wells representative of the landuse types. Sample the wells for selected constituents with a ground water contamination potential. Compile data on pesticide usage, including type and application quantities. Evaluate pesticide contamination potential based on chemical properties and transport, using simple unsaturated-zone flow models. Install and sample nests of wells in a typical cross-section of the citrus area to determine vertical patterns of flow and quality. Statistically examine data for evidence of ground water contamination and for factors affecting ground-water quality in each land-use type. Test conclusions by sampling in different areas of similar land use.

PROGRESS: Sites for wells were selected in the citrus area, the urban area, and in the control area. The wells in the control area (seven wells) and the urban area (three wells) were installed, developed, and sampled. Other wells in the control area and the urban area were also sampled for nutrients, major ions, metals, and organics. A total of 20 wells in the control area and 15 wells in the urban area were sampled. A first draft of the final report sections concerning introduction, previous work, other studies, and methodology was completed. 
(FL-422)

PLANS FOR THIS YEAR: Install and sample wells in the Citrus and Mining areas. Compile data from other studies related to this project. Develop conceptual models of contamination potential in the Citrus area and the Urban area.

\section{REPORTS RELEASED:}

Rutledge, A.T., 1986, Effects of land use on ground-water quality in central Florida--preliminary results: U.S. Geological Survey Water Resources Investigation Report 86-4163. 
FL-430 GEOLOGICAL CONTROLS ON GROUND-WATER MOVBMENT AND CONTAMINATION IN POLK COUNTY, FLORIDA

DATE PROJECT BEGAN: October 1984

DATE PROJECT ENDS: September 1988

PRINCIPAL INVESTIGATOR: G. L. Barr, Tampa

COOPERATING AGENCIES: Southwest Florida Water Management District and Polk County

PROBLEM: Polk County in central Florida has a diversity of water-quality problems that are apparently related to geologic structure. The principal aquifers consists of carbonate rocks that have actively-developing sinkholes. Localized incidents of ground-water degradation emphasize the vulnerability of the aquifer system to natural hazards and to man's activities. The need exists for a comprehensive study that will provide water managers and environmentalists with an effective program for understanding water-quality problems.

OBJECTIVE: Access water-quality problems both site specific and areally. Define areas that are susceptible to water-quality degradation by delineating the hydrogeologic framework, defining surface lineations, and mapping known sinkholes. Document areas of water-quality degradation with a water-quality monitoring program.

APPROACH: The project will involve the compilation of existing waterquality data and reported incidents of ground-water contamination. Aerial and satellite photographs will be evaluated as reconnaissance tools for defining surface lineations. Defined lineations will be related to waterquality problems or areas of potential water-quality degradation. Closed depressions will be defined and related to potential sources of contamination. A water-quality monitoring network of about 90 field-inventoried wells will be used to substantiate water quality conditions in areas of potential contamination. Site selection will focus on areas determined to have higher than normal probabilities for contamination of the aquifer units. The chemical quality of water samples will be analyzed in relation to hydrogeologic factors.

PROGRESS: Laboratory results of sampling (44 wells) performed in FY86 were received and stored into WATSTORE. Evaluation of water-quality results was completed. Well inventories for available wells were done and field checked for the FY-87 water-quality sampling. Water from 50 wells was collected (June-August) and sent for analysis to the USGS and Polk County laboratory. A gas chromatograph was used to scan water samples for the presence of selected volatile organic chemicals (VOC). Water from we1ls with negligible VOC's will be re-sampled in FY-88. Most laboratory results from the FY87 sampling were returned (except radiochemicals from Denver laboratory), checked, and stored into WATSTORE section. A draft to the introduction of report was completed; hydrogeology section was 
(FL-430)

started. A presentation of project activities and results was given in May 1987 to Polk County commissioners and staffers from the County's Water Resources and Environmental Services Divisions.

PIANS FOR THIS YEAR: Evaluate FY-87 laboratory results and re-sample wells as necessary. Complete report, send through review process and publish. 
FL-432 EFFECTS OF SLUDGE ON GROUND WATER QUALITY, DADE COUNTY, FLORIDA

DATE PROJECT BEGAN: October 1984

DATE PROJECT ENDS: September 1988

PRINCIPAL INVESTIGATOR: Barbara Howie, Miami

COOPERATING AGENCIES: South Dade Soil and Water Conservation District, and Florida Department of Environmental Regulation

PROBLEM: Because nutrients used in agriculture are rapidly lost by leaching from south Dade's Rockdale soils and by runoff from marl soils, growers want to use domestic wastewater treatment sludges as a soil conditioner and organic nitrogen source. There is a growing concern about what effect sludge application may have on ground-water quality in the Biscayne aquifer.

OBJECTIVE: To determine the effects of sludge application on ground-water quality, to compare the effects of sludge application with the effects of current practices of using fertilizers and soil conditioners and to develop a conceptual model explaining the fate of sludge constituents and the variations in effects on water quality.

APPROACH: Study elements will include determinations of the chemical contaminants present in ground-water and soil before and after sludge application to test plots comprised of south Dade's two soil types and two crop types. The migration of sludge contaminants will be investigated by determining the lithologic units where contaminants are most likely to move and by monitoring water levels in the vicinity of test plots. Records of rainfall, irrigation, fertilizers and sludge application at each plot will be maintained.

PROGRESS: Sludge was applied to the fourth sludge field. Multidepth wells at the four test fields were sampled for sludge-related contaminants and organic priority pollutants. A paper on the design of the monitoring network was prepared for publication in The American Society of Testing Materials (ASTM) conference proceedings.

PLANS FOR THIS YEAR: Data from Phase II will be interpreted and a final report prepared.

REPORTS IN PROCESS: None

REPORTS RELEASED:

Howie, Barbara, 1986, Effects of agriculture on ground-water quality in Dade County, Florida (Conference Proceedings).

Waller, B.G., and Howie, Barbara, 1987, Determining nonpoint-source contamination in an unconfined aquifer, Dade County, Florida: Procedures and preliminary results (Conference Proceedings). 
FL-439 NUMERCIAL STMULATION OF THE MIGRATION OF LANDFILI LRACHATE IN A HIGHLY PERIRABIR SURFICIAL AQUIFER, PALY BEACH COUITY, FLORIDA

DATE PROJECT BEGAN: June 1985

DATE PROJECT ENDS: September 1988

PRINCIPAL_INVESTIGATOR: Gary M. Russe11, Stuart

COOPERATING AGENCY: Palm Beach County Solid Waste Authority

PROBLEM: Landfills are one of the principal sources of contamination threatening the highly permeable surficial aquifer system of coastal Palm Beach County. Most of the studies of landfills have been based solely on water-quality sampling and generally have descriptive objectives only, and do not attempt to fully define the hydraulic controls on contaminate migration. Responsible agencies recognize the need to progress beyond merely descriptive studies of leachate migration to analytical approaches that describe the physical and chemical processes that govern leachate movement. Needed are deterministic models of the hydraulic regime and transport processes taking place at a landfill.

OBJECTIVES: Describe the process of leachate migration from a landfill in an unconfined, partially-cemented carbonate aquifer using cross-sectional and/or three-dimensional computer models. Use computer models to validate the conceptual model of the migration process, to simulate the actual transport of leachate that has occurred, and to evaluate the likely future migration under long-term normal hydrologic conditions and under short-term highstress conditions (severe storms). Extrapolate the results of the landfill simulation to other landfills in Palm Beach County as appropriate.

APPROACH: The data-collection effort and its time frame will be designed to answer the needs of the developing interpretative analysis of the landfill site. It will include an effort to improve estimates of hydraulic parameters and to obtain dispersivity parameters. The modeling analysis will include a hydraulic simulation of the site and the simulation of transport of conservative substances in the leachate. If linear hydraulic symmetry prevalls along the axis of the leachate plume, a cross-sectional model design will be used for hydraulic analysis. Otherwise, the model will be three dimensional.

PROGRESS: Installed and sampled eleven water quality wells with multiple sampling points at 5 foot intervals to 70 feet. Flow model has been constructed and 3-dimensional calibration is in progress.

PLANS FOR THIS YEAR: Continue flow model simulation and sensitivity analysis and begin solute transport modeling. Complete planned WRI documenting modeling activities. 
(FL-439)

REPORTS IN PROCESS: None

\section{REPORTS RELEASED:}

Russe11, G. M., 1986, Reconnaissance of landfill-generated plumes in lowrelief areas, southeast Florida (Journal Article)

Russe11, G. M., Assessment of ground-water contamination along the eastern perimeter of the Lantana landfill, Palm Beach County, Florida (Journal Article) 
FL-442 EFFECTS OF SEPTIC TANRS AND DOMESTIC WELIS ON WATER QUALITY AND LEVELS, NORTHEAST PALY BEACH COUNTY, FLORIDA

DATE PROJECT BEGAN: October 1985

DATE PROJECT ENDS: September 1988

PRINCIPAL INVESTIGATOR: Wesley L. Miller, Miami

COOPERATING AGENCY: Palm Beach County

PROBLEY: Rapid development of residential home sites serviced by septic tanks and private well is anticipated in northeast Palm Beach County. The area of about $250 \mathrm{~m}^{2}$ is presently undeveloped, but 15,000 to 20,000 homes may be built by the year 2000. Little existing data is avallable about the surficial aquifer system's water quality, hydraulic characteristics, or geology in the area. Near surface marls and frequent flooding may retard attenuation of septic tank effluent and allow contamination of the area's ground-water.

OBJECTIVES: (1) Determine the location, thickness, and extent of marls in the upper 50 feet of the aquifer; (2) locate aquifer zones containing high chloride concentrations; (3) determine predevelopment ground-water quality; (4) determine attenuation of chemical, bacterial, and viral constituents in septic tank effluent in the hydrogeologic regime of the area; (5) provide ground-water level maps; and (6) provide pre-development ground-water level and quality data bases.

APPROACH: (1) Conduct surface geophysical surveys to locate any portions of the area in which the aquifer contains residual sea water and to determine locations, thickness, and areal extent of marl units in the upper 50-feet of aquifer; (2) select sites, using geophysical data, and drill suites of background water-quality sampling wells to various depths in the aquifer; (3) select existing septic tank sites; (4) drill and sample monitor well to determine attenuation of septic tank effluent; and (5) establish groundwater level measurement network of wells to monitor water-table fluctuations as the area developes.

PROGRESS: A water-quality network of 30 wells and 3 septic tank test sites (22 wells) was established and quarterly samples and measurements were collected. Ground-penetrating radar profiles totaling 35 miles were run to determine the locations and continuity of near surface marl units. Interpretation of the data continued.

PLANS FOR THIS YEAR: Complete sampling and prepare final report. 
FL-444 GEOHYDROLOGY OF THE SURFICIAL AQUIFER SYSTEM, VOLUSIA COUNTY, FLORIDA

DATE PROJECT BEGAN: October 1985

DATE PROJECT ENDS: September 1988

PRINCIPAL INVESTIGATOR: G. G. Phelps, Orlando

COOPERATING AGENCY: Volusia County

PROBLEM: The uppermost aquifer in Volusia County is the surficial aquifer system. To date there has been no systematic study of 1ithology, flow system, rates of recharge and discharge, or water quality of the surficial aquifer system. Salty water occurs in the surficial aquifer from a combination of factors that include: (1) upward leakage from the Floridan system, (2) lateral or vertical encroachment due to ground-water pumping, and (3) lateral or vertical encroachment caused by ditching for surface drainage. As growth continues in Volusia County, the surficial aquifer is destined to play an increasingly important role in the management of the county's ground-water resource with regard to both water supply and solid and liquid waste disposal.

OBJECTIVES: The objectives of the proposed investigation are to: (1) describe the 1 ithology and thickness of the surficial aquifer system in Volusia County, (2) map the thickness of the unsaturated zone, the water table, and the aquifer-flow system, (3) describe the water-quality characteristics and hydraulic characteristics of the aquifer system.

APPROACH: (1) Drill and sample approximately 500 shallow (1ess than 50 feet) wells and core holes into the surficial aquifer system, (2) conduct 1 or 2 short-term aquifer tests to determine hydraulic characteristics at selected sites, (3) map areas of potential upward leakage by comparing water table map with Floridan aquifer potentiometric maps.

PROGRESS: Drilled 27 wells into the surficial aquifer system to augment existing water-level network. Made natural-gamma logs of 20 wells to confirm layering of the surficial aquifer system. Sampled water from 50 wells for major constituents, nutrients and iron. Began analysis of geologic and geophysical data. Began statistical analysis of water quality data.

PLANS FOR THIS YEAR: Complete data analysis, write report, complete through colleague review. 
FL-445 ASSESSKENT OF WATER-QUALITY PROCESSES AFFECTING NUTRIENTS IN WETLANDS STREAM

DATE PROJECT BEGAN: October 1985

DATE PROJECT ENDS: September 1990

PRINCIPAL INVESTIGATOR: Paul S. Hampson, Orlando

COOPERATING AGENCY: Reedy Creek Improvement District

PROBLEM: Phosphorus concentrations in Reedy Creek are relatively high downstream from Walt Disney World is treated-sewage discharges. Dissolved oxygen concentrations are at times much lower than allowed by state regulations. The low Do may be due largely to natural runoff from swampy areas, or it may be related to nitrogen-conversion processes related to the wastewater effluent. Little is known about how Reedy Creek assimilates and cycles nutrients. A better understanding of the efficiency of wetlands streams in nutrient assimilation, and the effect of nutrient enrichment on such streams is required.

OBJECTIVES: Define the hydrologic environment of the Reedy Creek wetlands system in terms of water storage capacity, mean depth, stage duration, and water residence time. Evaluate role of wetlands in nutrient cycling and DO variation. Determine loads and speciation of nitrogen and phosphorus at selected points in the basin. Measure the nutrient-retention capacity of the RCID wetlands, and the effect of the wetlands on downstream water quality.

APPROACH: The methods used to accomplish the objectives will require six different types of data collection. These are: sampling of soil cores and sediments from the wetlands; insitu experiments to measure sediment oxygen demand and mechanism of nutrient cycling; aerial and field surveys for determination of flooded area and water depth; operation of continuous DO monitors and streamflow stations; sampling of nutrients at selected load stations under a range of discharge conditions; and collection of samples along Reedy Creek to establish profiles of water quality.

PROGRESS: Nutrient samples have been collected at six locations on Reedy Creek for the determination of nutrient loading. Seven datalogger sites were established at gated structures controlling inflow to the developed portions of the basin and ratings were constructed from discharge measurements at each site. Six water-quality monitors have been operated for continuous measurement of specific conductance, dissolved oxygen and temperature.

PLANS FOR THIS YEAR:

Continue operation of continuous monitors and the collection of waterquality, sediment and discharge data. Upgrade the existing meteorological stations in the basin with new equipment. Design and perform reaeration coefficient measurements on the middle and lower reaches of Reedy Creek. 


\section{FL-446 WATER RESOURCES EVALUATION OF THE FRESHWATER LENS ON KEY WEST, FLORIDA}

DATE PROJECT BEGAN: October 1985

DATE PROJECT ENDS: September 1988

PRINCIPAL INVESTIGATOR: Donald J. McKenzie, Miami

COOPERATING AGENCY: South Florida Water Management District

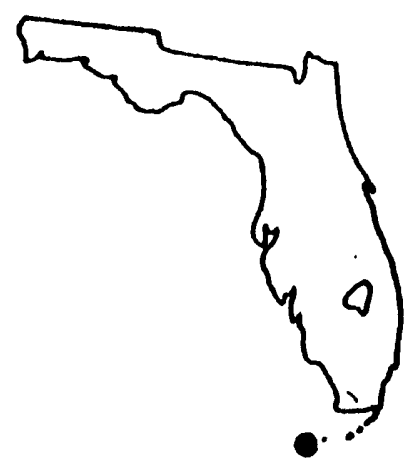

PROBLEM: A freshwater lens beneath the island of Key West is used by some residents as a potable water supply. The lens and the saline water beneath it have also become a repository for stormwater and treated wastewater. The freshwater lens needs to be evaluated to determine the water-supply potential and the quality of the water.

OBJECTIVES: (1) Determine the areal extent and thickness of the freshwater lens on Key West, taking into account seasonal and tidal changes in the extent and thickness of the lens; (2) determine the areal variation in water quality of the freshwater lens.

APPROACH: A geophysical survey, if feasible, and wells drilled along transect lines will be used to describe the extent of the freshwater lens. Additional wells will be drilled to determine ambient groundwater quality and contaminants near the injection points of stormwater and wastewater. Tide gages and water level recorders will be used to determine the relation between tidal action and lens thickness.

PROGRESS: The second water quality sampling was conducted and groundwater level data continued to be collected. Groundwater levels were greatly influenced by tidal fluctuations and with little lag time. The major influence on the groundwater quality was salt water mixing, but there was some point source contamination indicated.

PLANS FOR THIS YEAR: Sample selected wells for pesticides and synthetic organic compounds: Sample wells in most densely populated part of island for nitrogen compounds and coliform bacteria to determine possible influence from municipal sewage pipes. 


\section{FL-447 SALINITY CHARACTERISTICS AND EFFECTS OF FRESHWATER}

WITHDRAWALS, MYAKRA RIVER, FLORIDA

DATE PROJECT BEGAN: October 1985

DATE PROJECT ENDS: September 1988

PRINCIPAL INVESTIGATOR: Kathleen M. Hammett, Tampa

\section{COOPERATING AGENCY: Sarasota County}

PROBLEM: Demands for freshwater are increasing in coastal areas of southwest Florida. Coastal streams like the Myakka River may be used to augment present supplies. Withdrawal or diversion of freshwater from the stream may result in upstream encroachment of saltwater and elevated salinity levels in the estuarine reach of the stream. Changes in salinity may produce adverse biological changes. Salinity characteristics must be evaluated prior to withdrawal or diversion for water supply.

OBJECTIVES: Describe in detail the salinity characteristics of the Myakka River estuary for a wide range of freshwater inflow and tide conditions. Develop mathematical relations describing salinity as a function of freshwater inflow and astronomical tide. Evaluate water-supply potential of the Myakka River and evaluate alternative plans for water-supply withdrawal. Evaluate projected effects of withdrawal on the salinity distributions using the mathematical relations developed in objective 2 .

APPROACH: Tide and salinity will be monitored at one temporary and three permanent stations. Specific conductance will be measured as part of periodic field surveys for a wide range of freshwater inflow and tide conditions. Multiple linear regression analysis will be used to relate salinity to daily mean discharge for selected tidal stages. Low-flow frequency analysis of existing gaging-station records and draft-storage analysis of existing lakes and potential storage areas will be used to evaluate watersupply potential. Regression equations will be used to define the location of the salt front for possible withdrawals or diversions.

PROGRESS: Data collection was completed. Preliminary regression analyses have standard errors comparable to those from studies of other tidal rivers. An annotated outline of the final report is in preparation.

PLANS FOR THIS YEAR: Finalize regression analysis. Evaluate potential freshwater withdrawals. Prepare final report. 
FL-449 SIMULATION OF A SALTWATER PLUME FROM A FLOWING WELL IN A SURFICIAL AQUIFER, DADE COUNTY, FLORIDA

DATE PROJECT BEGAN: January 1986

DATE PROJECT ENDS: September 1988

PRINCIPAL INVESTIGATOR: Michael L. Merritt, Miami

COOPERATING AGENCY: Metro-Dade Environmental Resources Management

PROBLEM: Water supply in highly populated southeastern peninsular Florida is obtained almost entirely from the surficial aquifer. The presence of a chloride plume in the aquifer was established in 1979 and traced to a flowing well in Chekika State Park that was constructed in 1944 . It was plugged in March 1985. Dade County plans to develop a new wellfield to the northeast of the plume, and concerns exist about possible wellfield contamination and about the future movement and rate of dilution of the plume.

OBJECTIVES: The objectives are to obtain information about the hydrologic regime in the surficial aquifer of south central Dade County and about the local movement and dispersal of pollutants, and to use this information to assess the future migration and attenuation of the chloride plume and the possibility of contamination of water withdrawn from the proposed new wellfield.

APPROACH: Digital models will be constructed to represent flow and transport in the area containing the chloride plume. Information used to design the models will include descriptions of rock samples and cores and the results of hydraulic testing now taking place as part of a separate study. Information used to calibrate the model will include the results of a synoptic QW reconnaissance by the USGS in 1979, a time series of QW data collected by DERM at various sites since 1981, and surface resistivity surveys in 1979 and 1986. The hydraulic regime will be simulated first, to be followed by chloride transport calculations and analyses to predict future plume movement and assess possible wellfield contamination.

PROGRESS: The SWIP groundwater hydraulic and transport code was modified to include a generalized representation of overland surface flow and its interaction with flowing ground water. It was also modified to permit assignment of seasonally varying constant pressure boundary conditions and areal recharge and evapotranspiration rates. Then began calibration of the code to represent period-of-record average (but seasonally varying) elevations in the low and marshy southern two-thirds of Dade County in five distinct time periods corresponding to stages in the development of the water management system. Good qualitative agreement between observed and computed hydrographs at surface and groundwater stations with continuous record in three time periods has been achieved. 
(FL-449)

PLANS FOR THIS YFAR: The calibration of the flow model will be refined and extended to later time periods in which more data points are available for comparison. A special problem will be to verify the simulation of canals that transect the modeled area in later time periods. The model will be modified to provide a set of boundary conditions for a smaller-scale simulation of chloride transport in the area surrounding Chekika State Park. Simulation of the effect of wellfield pumping will take place. The final step will be preparation of project reports. 
FL-451 NUTRIENT LOADS IN THE APOPKA-BEAUCLAIR GANAL, UPPER OKLAWAHA BASIN, CENTRAL FLORIDA

DATE PROJECT BEGAN: May 1986

DATE PROJECT ENDS: September 1988

PRINCIPAL INVESTIGATOR: Donna M. Schiffer, Orlando

COOPERATING AGENCY: St. Johns River Water Management District and Lake County

PROBLEM: The water entering Lake Beauclair is thought to have high nutrient concentrations. Presently, two sources of nutrient are suspect--Lake Apopka and the muck-farming operations adjacent to the Apopka-Beauclair Canal. The problem is to determine the relative contribution of nutrients from each source.

OBJECTIVES: Collect discharge data and nutrient data for the ApopkaBeauclair Canal in order to determine the nutrient loads leaving Lake Apopka and those entering Lake Beauclair. The difference between the input and output loads of the canal will be considered as the load entering from the muck farms.

APPROACH: The geographic scope of the study will be the uppermost lakes of the upper Oklawaha basin, with the main emphasis on the northern outlet of Lake Apopka and the Apopka-Beauclair Canal. For waters entering the canal from the muck-farm area, flows may have to be estimated. Data will be collected for 2 years; the 3 rd year of the study will be devoted to writing and processing the report.

Instrumentation at each site will include an electro-magnetic current meter for gaging purposes, and a microprocessor-controlled water-quality sampling system. The latter will also include continuous monitoring of temperature, specific conductance, and dissolved oxygen.

Discharge gaging will be conducted on a continuous basis, limited only by equipment failure and maintenance problems. Water sampling will be carried out as two entities--one covering seasonal flow and one covering stormwater flow.

Analysis of the field-collected data will begin by calculating canal discharge and having nutrient concentrations analyzed in the laboratory.

PROGRESS: Data were collected for the entire year at the two study sites. Data collected on a continuous basis at each site include stage, temperature, conductance and dissolved oxygen. At the lock-and-dam site continuous data were also collected for rainfall and the two radial-arm gates. At the upstream site, velocity data were collected during storm events. Water quality samples were taken at each site on a monthly basis. One major storm event, with an estimated recurrence interval of 10 to 20 years, was experienced. Discharge measurements were made at both sites during the event and water quality samples were taken at preselected sites throughout the study area. 
(FL-451)

PLANS FOR THIS YEAR: Routine data collection will be continued at the two data collection sites and bed sediment and water quality sampling during low water will be carried out at selected sites in the study area. Data analysis will begin and the report outline will be prepared. 


\section{FL-452 DELINEATION OF PROTECTION ZONES AROUND PUBLIC-SUPPLY WELLS IN FLORIDA}

DATE PROJECT BEGAN: October 1986

DATE PROJECT ENDS: September 1989

PRINCIPAL INVESTIGATOR: James D. Hunn, Tallahassee

COOPERATING AGENCY: Florida Department of Environmental Regulation

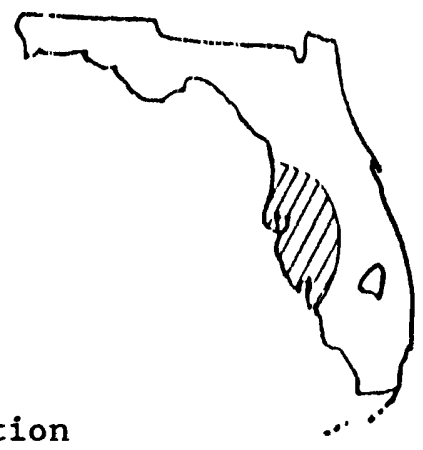

PROBLEM: Aquifers in much of Florida are vulnerable to contamination be cause they occur at shallow depths and may be overlain by highly permeable materials. The Florida Department of Environmental Regulation (FDER) is developing regulations to protect vulnerable segments of aquifers that are for public supply. FDER requested the U.S. Geological Survey to delineate "protection zones" around public-supply wells and well fields that tap aquifers vulnerable to contamination from the land surface.

OBJECTIVES: Evaluate hydrogeologic conditions at public-supply well sites and calculate the size of individual "protection zones" around each well or well field tapping unconfined aquifers or "leaky confined aquifers."

APPROACH: The first phase of the study will be made in west-central Florida in which all public-supply wells or well fields producting 100,000 gal/day or more will be evaluated. The results and methodology will then be applied statewide. Areas containing unconfined and leaky confined aquifers will be delineated. A 1ist of municipal supply wells will be assembled using water management district data. "Protection zones" around individual wells will be constructed that extend to the radius of a cylinder of aquifer around the we 11 that contains a volume of water equal to 5 years of permitted pumpage. Protection zones of well fields will be determined diagramatically.

PROGRESS: A preliminary report of the first phase of the study was prepared and is in review. The statewide phase of the study was begun.

PLANS FOR THIS YEAR: Delineate protection zones for northern south-west Florida, around wells and well fields producing 100,000 gallons per day or more from unconfined or "leaky confined" aquifers. 
FL-454 WASTE CONTAKINATION USING A GEOGRAPHICAL INFORMATION SYSTEM

DATE PROJECT BEGAN: October 1986

DATE PROJECT ENDS: September 1989

PRINCIPAL INVESTIGATOR: Bradley G. Waller, Miami

COOPERATING AGENCY: South Florida Water Management District

PROBLEM: The southeast coast of Florida which stretches from Palm Beach County on the north to Dade County on the south which has a population that is projected to increase from 3 to 5.5 million people in the next 15 years. This projected growth in population will increase the demand for drainage and water supply, thereby placing a greater stress on the water resources of the area and requiring more intense water management. Presently, more than 90 percent of the nearly 1 billion gallons per day of water used on the southeast coast comes from ground-water sources, primarily from the sole source aquifer. County agencies are formulating county-wide well-field protection ordinances and are in need of a means to assess isk of groundwater contamination within the cones of influence. At preser, there is no method to correlate probable contamination versus land $v \geqslant$ within these cones of influence.

OBJECTIVES: Develop a procedure to assess the probability of contamination, based on land-use information, flow direction, hydrogeologi characteristics, time-of-travel models, water use, and known contamir at sources, in the cone of influence of wells using a GIS (geographic infor ation system) as a data-base management tool.

APPROACH: Existing data bases would be analyzed to determine how to best enter these data to maintain both accuracy and spatial integrity. Most data bases (coverages) will be digitized, and information tables formatted. Some of the data are already in a digital format, and the spatial coverages and information tables can be processed without digitizing and hand entering data. These data can then be combined to produce various coverages with accompanying information tables for evaluation of waste hazard potential near well fields.

PROGRESS: All data layers entered for the Broward County test area. Coverages done under subcontract included Dept. of Revenue tax-based real estate data, water-use coefficients, township/range/section polygon grid, and DRASTIC geohydrologic analysis. Most coverages for Dade and Palm Beach Counties have been entered and checked. Waste hazard evaluation algorithm have been determined.

PLANS FOR THIS YEAR: Complete analysis of Broward County test areas. Finish planned reports. Extend waste hazard evaluation to Dade and Palm Beach counties. Assist County and State Agencies develop ground-water monitoring networks and wellfield protection strategies based on the data base management system developed. 
(FL-454)

\section{REPORTS IN PROCESS:}

Waller, B.G., 1988, Ground-water protection strategies developed from real estate tax based data using a grographic information system (Conference Paper).

Waller, B.G., and Higer, A.L., 1988, Design of a GIS data base management system to develop a ground-water quality management model in Broward County, Florida (Conference Paper). 
FL-455 FEASIBILITY OF STORING FRESHTATER IN SUBSURFACE

FORYATIONS, CAPE CORAL, LEE COUNTY, FLORIDA

DATE PROJECT BEGAN: October 1986

DATE PROJECT ENDS: September 1989

PRINCIPAL INVESTIGATOR: E. J. Wexler, Miami

COOPERATING AGENCIES: South Florida Water Management District and City of Cape Coral

PROBLEM: Cape Coral is a southwest Florida coastal city, whose freshground-water resources are heavily stressed. The city has a 8.8 MGD reverse osmosis plant that utilizes saline ground water but the current growth rate of 29 percent, will soon stress this resource also. The city has about 300 miles of freshwater canals. It has been proposed that excess runoff during the rainy season should be stored in deep saline aquifers as an additional source of supply during the high-demand dry season. First, the excess freshwater canal runoff must be quantified and an appropriate ground-water aquifer storage site needs to be investigated. Next, digital modelings need to be developed for the Cape Coral area to test the various methods of storage/retrieval and recharge schemes.

OBJECTIVES: To define the runoff pattern of the freshwater canal system, assess quantities of excess runoff occurring during the wet season, and assess the feasibility of conserving this freshwater in Cape Coral by artificial recharge or subsurface storage. Secondarily, to develop a multivariate relation among recovery efficiency, aquifer permeability, and cost, constrained by maximum permitted injection pressure and selected values for native aquifer water salinity.

APPROACH: Excess runoff and pattern of runoff will be determined from surface-water records from selected freshwater canal sites. Geohydrological data will be used as a basis for construction of digital flow and transport models. Digital modeling will be used to evaluate proposed injection, storage, and recovery for recovery efficiency after multiple cycles. Digital modeling will also be used to determine the optimum relationship between aquifer transmissivity, recovery efficiency, and cost of pumping for various values of native water salinity.

PROGRESS: All surface water stations were installed and are operational.

PLANS FOR THIS YEAR: Review surface water data and assess runoff. 
FL-456 IMPACT OF PUMPING AT THE NORTHWEST WELLFIELD ON ADJACENT WETLANDS, DADE COUNTY, FLORIDA

DATE PROJECT BEGAN: October 1986

DATE PROJECT ENDS: September 1988

PRINCIPAL INVESTIGATOR: Roy S. Sonenshein, Miami

COOPERATING AGENCY: South Florida Water Management District

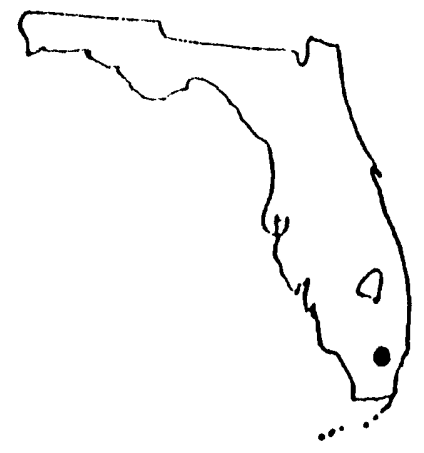

PROBLEM: Aside from the need to protect well fields from various land uses, the need to protect the ecological system is paramount. One such ecological system, which is known for aesthetic value in Dade County, are the wetland areas. The northwest well field operated by the Miami-Dade Water and Sewer Authority is sited in a wetland area. Continuous wellfield withdrawal could lower the water levels within this wetland and may have detrimental effects on a wide range of fauna and flora.

OBJECTIVES: To delineate the area surrounding the wellfield within which water levels are lowered sufficiently to impact the wetland status of the area.

APPROACH: Long term water levels for observation wells in the area will be analyzed. Stage duration and depth below land surface will be compared with criteria which define the limits for wetland vegetation. Water-level contour maps will be produced during dry period recessions for 2 years. Subsurface profiles of the water table will be prepared to indicate the relationship between the water table and the land surface. Maps will be computer generated to delineate the area affected by changes of wetland status.

PROGRESS: Four wells were installed. Water levels were collected at these and other wells to determine the extent of the cone of influence. Historical data were entered into the computer and statistical analyses were begun. Aerial photographs from before and after pumping began were compared to determine changes in vegetative patterns.

PLANS FOR THIS YEAR: Analyze historical record. Prepare contour maps, subsurface profiles and vegetative maps. Prepare report for publication. 
DATE PROJECT BEGAN: October 1986

DATE PROJECT ENDS: September 1990

PRINCIPAI INVESTIGATOR: Roger P. Rumenik, Tallahassee

COOPERATING AGENCY: Florida Department of Environmental Regulation

PROBLEM: A rapid growth in State population and the increased demand for environmental protection has emphasized a need for information on low stream flows. Low-flow frequency information is needed to assess water-supply potential and waste-load assimilation capacity of streams in Florida.

OBJECTIVES: (1) Develop a centralized computer-storage data base for existing misceilaneous measurements. (2) Determine low-flow frequencies ( 7 - and 30-day 2-year, and 7-and 30-day 10-year low-flow) for daily-record stations, and for partial-record stations where data can be correlated with long-term index stations. (3) Prepare a report that describes the data base useage, and presents low-flow data and frequency information.

APPROACH: Enter all miscellaneous streamflow-measurement data in the MEAS/INSP File of the WRD ADAPS (System), selected as the project's data base. Test and select distributions that best define low-flow frequencies for daily-record stations. Evaluate the adequacy of correlation between partial-record stations and dafly-record index stations using P-STAT programs on the Prime computer, and determine low-flow frequencies when correlations exist. Prepare final report that describes the data base usages, and presents low-flow data and frequency information in text and map format.

PROGRESS: Miscellaneous streamflow-measurement data have been entered into the USGS Automatic data Processing System (ADAPS) for 808 of 1,600 estimated sites. The ADAPS MEAS/INSP file was selected as the centralized computer data base for Florida. Five USGS offices in Florida participated in the data entry under the direct coordination and review of the project chief. A plan for testing several distributions for selected streamflow stations to define low-flow frequencies has been formulated.

PLANS FOR THIS YEAR: Complete the data entry of all miscellaneous streamflow-measurements into a computerized data base. Determine magnitude and frequency of low flows for daily-record streamflow stations. Begin procedures to correlate data from partial-record stations with data at longterm index stations. 


\section{FL-458 SALTWATER-FRESHWATER INTERFACE IN THE COASTAL AREA OF SOUTHWEST FLORIDA}

DATE PROJECT BEGAN: October 1986

DATE PROJECT ENDS: September 1991

PRINCIPAL INVESTIGATOR: Judy D. Fretwe11, Tampa

COOPERATING AGENCIES: Southwest Florida Water Management District and West Coast Regional Water Supply Authority

PROBLEM: Increased ground-water development associated with a rapidly growing population along the southwest coast of Florida poses a threat of contamination to major freshwater supplies through the introduction of saltwater into the upper Floridan and intermediate aquifers. To predict and prevent this occurrence, it is necessary to define the present location of the saltwater-freshwater transition zone in the major ground-water production zones along the southwest Florida coast.

OBJECTIVES: (1) To select and monitor 50 to 75 primary wells and up to 250 secondary wells in and near the transition zone in the major ground-water producing areas of the coastal area of southwest Florida, (2) to describe each monitor well by defining the hydro-geologic setting, (3) to recommend frequency of sampling, sampling protocol, and chemical analyses, (4) to describe short- and long-term changes in chloride concentration and specific conductance with time at selected wells, and (5) to use the data collected to define the location of the saltwater-freshwater transition zone.

APPROACH: (1) Compile available data including water-level, water-quality, well-construction and geophysical data. (2) Collect new data as necessary to supplement and update existing data which will include: a) Surface-DC resistivity and/or EM induction surveys; b) Borehole geophysical logging; c) Water-quality analysis for chloride, sulfate, specific conductance, density and temperature, and d) Continuous specific conductance and water-level monitoring at selected sites.

PROGRESS: A planning document and initial literature search has been completed. The project has been reviewed by District, Region, and cooperator staff at ten percent completion. Comprehensive data on existing and potential transition-zone monitor wells have been compiled. Data includes information on location, lithology, well construction, sampling methods and frequency, water-quality, geophysics, and other pertinant information. Geophysical logging of eight wells has been completed. Another 20 sites have been selected for logging. Logs are run to determine well construction and hydrogeology at the site. Three long-term and two short-term sites have been instrumented for continuous monitoring of water leve1, specific conductance, and temperature. Several other temporary sites have been selected for future monitoring. These monitors provide information on short term changes in water quality in a well. Water-quality samples have been collected from approximate1y 200 we11s in May and September (dry and wet seasons). Specific conductance, chloride, sulfate and temperature analyses 
(FL-458)

have been made on most samples and density analysis on many. Lab analysis and mothods of sampling woro comparod among tho cooporating agencios. Data collected has beon procossod and stored in preparation for analysis. An initial monitor network has been established.

PIANS FOR THIS YEAR: Geophysical logging will continue. Leveling of wells to soa-lovel will be initiated. Minl-monitors will be rotated as necessary and data will continue to be processed, stored, analyzed, and interpreted. Water-quality samples will be collected in May and September at approximately 200 wells. Samples will be analyzed for specific conductance, temperature, chloride, sulfate, and additional parameters of calcium, magnesium, potassium, sodium, fluoride, silica, pH, and alkalinity at selected sites, Water levels will also be measured when the sample is collected. The initial water-quality data-base will be reviewed and adjusted as deemed necessary based on new data. Manuscript preparation will continue. A forty percent completion peer review will be scheduled around September. 


\section{FL-459 SOURCES OF NITROGEN IN GROUND WATER FROM AREAS SUBJECT TO APPLICATION OF WASTEWATER BY SPRAY IRRIGATION AND COMMERCIAL FERTILIZERS NEAR TALLAHASSEE, FLORIDA}

DATE PROJECT BEGAN: October 1986

DATE PROJECT ENDS: September 1988

PRINCIPAL INVESTIGATOR: Marian P. Berndt, Tallahassee

COOPERATING AGENCIES: City of Tallahassee, Underground Utilities

PROBLEM: Nitrate concentrations in water from wells at two wastewater irrigation sites near Tallahassee have exceeded the State maximum contaminant level of $10 \mathrm{mg} / \mathrm{L}$ in drinking water. A concurrent rise in concentrations of the conservative tracer, chloride, in water from these wells and high concentrations of chloride and nitrate measured in effluent samples suggests the source of ground-water contamination by these two constituents can be attributed to spray irrigation of municipal treated wastewater. The southeast site also received commercial fertilizers which may contribute to nitrate concentrations in ground-water. Removal of nitrate by plants and soil may not balance the combined nitrate input from the irrigation water and fertilizers, allowing transport of excess nitrate to groundwater.

OBJECTIVES: (1) Significance of the various sources of nitrogen to the southeast wastewater spray irrigation site, and (2) to determine the proportion of nitrate nitrogen contributed to ground water from wastewater, from fertilizers, and from other sources.

APPROACH: Samples will be collected at the southeast and southwest sites from wastewater, crops, fertilizer, water from the unsaturated zone, precipitation and wells in the shallow sediments and the upper part of the Floridan aquifer. Measurements of the major forms of nitrogen (nitrate, nitrite, ammonia, and organic nitrogen) and nitrogen isotope ratios will be the major analytical concern. Conservative tracers of groundwater contamination, such as chloride, sodium and specific conductance will also be measured. Data will be collected monthly for one year. Data analysis will include six years of existing well data.

PROGRESS: Samples were collected for analysis of nitrogen isotopes and preliminary results are being analyzed. Sixteen new surficial wells have been installed to monitor nitrate concentrations above the Floridan aquifer. Data collection and analysis of results are continuing for groundwater samples taken at the site. Lysimeters installed at selected locations to monitor nitrogen concentration in the unsaturated zone.

PLANS FOR THIS YEAR: Collect samples from lysimeters to measure nitrogen concentrations in the unsaturated zone. Collect monthly samples from wells in shallow sediments and the upper part of the Floridan aquifer, and from irrigation spray heads, for measurement of major forms of nitrogen, nitrogen isotope ratios and conservative tracers. Collect samples from precipitation monitoring stations following rain events, for measurement of major forms of nitrogen. Compile historical data on fertilizer application rates. 
FL-460 GROUND WATER HYDROLOGY OF THE SURFICIAL AND FLORIDAN AQUIFER SYSTEYS IN OSCEOLA AND OREECHOBEE COUNTY

DATE PROJECT BEGAN: October 1986

DATE PROJECT ENDS: September 1990

PRINCIPAL INVESTIGATOR: George R. Schiner, Orlando

COOPERATING AGENCIES: South Florida Water Management District and St. Johns River Water Management District

PROBLEM: Osceola County is undergoing a rapid growth in population, more than doubling in the last 5 years. With this growth, the need for additional water supplies is becoming more acute. Evaluation of water use and water supply potential is particularly needed for the rural areas that have been Incorporated or taken over by cities. More than 90 percent of all water used by domestic, municipal, and agriculture water users is obtained from the Floridan aquifer system, the rest is supplied by the overlying surficial aquifer system. Overdraft could result in water-quality degradation from saltwater intrusion.

OBJECTIVES: (1) To determine the relations between rainfall and water levels to aquifers, (2) to describe the hydrologic and water-quality characteristics of the aquifers and their individual and collective response to changes in recharge, and to pumping, (3) to delineate areas where water quality or quantity is or may become a problem, (4) to establish a network of hydrologic stations to monitor water level changes in the major aquifers, and changes in water quality in ground waters and (5) to prepare an interpretative report.

APPROACH: (1) Prepare a page size base map showing major drainage, cul tural, and political features. (2) Collect and synthesize historical waterresources information from published and unpublished reports. (3) Inventory existing wells. (4) Geophysically log and sample wells for water-quality. (5) Drill 5-12 test observations wells and collect information on water levels, lithology, and water quality. (6) Conduct specific capacity, or short-term aquifer tests. Conduct longer-term aquifer tests on selected wells. (7) Establish a hydrologic network and install instruments.

PROGRESS: All quality of water, water level, and well data for Osceola County were catalogued and retrieved from the U.S.G.S. computer files. Information in the computer files was extracted and collated. Computer files were prepared to plot data relating to surficial and Floridan aquifer wells. Well locations were plotted. Previous reports pertinent to the study were examined and the useful data extracted. Meetings were held with various county and city government officials to both explain the project and to assess the availability of project data. Private consultants known to be active in Osceola County were contacted for information. A page-sized base map for the final report was drawn. Water from all flowing wells measured for the Osceola portion of the May 1987 potentiometric surface map were sampled for chloride concentration. Surficial and Floridian aquifer system 
(FL-460)

wells were located in the field to add to data bases. Initial selection of wells was made for sampling, measuring, geophysical logging and aquifer testing. Several sites were located for test drilling. Areas where additional hydrologic information is needed were outlined. A planning document was prepared together with time lines for specific tasks. A continuous recorder was installed on a well that taps the Floridian aquifer system. Preliminary writing of the report and compilation of illustrations began.

PLANS FOR THIS YEAR: Drill at least five test wells and retain for observation well network. Run aquifer tests and sample test wells for water quality. Run geophysical logs on test wells and newly inventoried wells. Complete final report. 
FL-461 EVAPOTRANSPIRATION FROM AREAS OF NATIVE VEGETATION IN CENTRAL FLORIDA

DATE PROJECT BEGAN: October 1986

DATE PROJECT ENDS: September 1991

PRINCIPAL INVESTIGATOR: Miguel A. Lopez, Tampa

COOPERATING AGENCIES: Sarasota County, Southwest Florida Water Management District and West Coast Regional Water Supply Authority

PROBLEM: Water avallability is becoming a critical issue even in humid, subtropical climates. By understanding and quantifying the components of the water budget in such areas, unique solutions may be developed to manage water resources. Although evapotranspiration is by far the major component of the water budget in humid, sub-tropical climates, very little has been done to obtain reliable estimates of evapotranspiration (ET). Accurate estimates of ET of four common, major native vegetation types in central Florida will be determined by selected energy budget techniques. The results of this investigation will provide a significant new knowledge by developing more accurate ET values for extensive and ecologically important wetland areas.

OBJECTIVES: The objectives of the study are: 1) to develop accurate estimates of evapotranspiration from palmetto prairie, pine flat woods, grass ponds and cypress heads in the Ringling-MacArthur Reserve and the Cypress Creek and Big Cypress swamp area, 2) to estimate total ET from RMR, and 3) to analyze for error in the estimated ET.

APPROACH: The approach to this study will include delineating areas of native vegetation in the study area; and evaluating the use of energy budget techniques, e.g., Penman, Bowen ratio and eddy correlation using two years of field data and estimate ET for the study area using the best applicable techniques. Vegetative cover will be delineated with detalled aerial color photography. Field data collection sites will be selected, assuring that sites are representative for each vegetative type. Periods of monitoring for each site will be (a) permanent-continuous for parameters used in calculating ET by the Penman method and (b) portable short-term for parameters used in energy budget techniques, generally monthly to bi-monthly for 24 to 48 hour periods.

PROGRESS: Permanent-continuous sites for measuring ET by the Modified Penman method and Bowen Ratio method were selected in the RMR and Starkey well field areas. Short-term ET measurement sites were selected; three each in palmetto prairie, pine flat woods, and grassy ponds in Sarasota County, and one in a cypress head in Starkey well field, Pasco County.

PLANS FOR THIS YEAR: Install the permanent-continuous ET measurement equipment at one site and make one- to two-day measurements of ET at the nine short-term ET monitor sites in Sarasota County. Install the permanentcontinuous ET measurement equipment at one site and make one- to two-day measurements of ET at the cypress head site in Starkey well field. Process and store field data. 
FL-462 POTENTIOMENTRIC MAPS OF THE INTERMEDIATE AQUIFER SYSTEM, WEST-CENTRAL FLORIDA, SUMMARY OF HYDROLOGIC CONDITIONS FOR HIGH AND LOW WATER

DATE PROJECT BEGAN: October 1986

DATE PROJECT ENDS: September 1989

PRINCIPAL INVESTIGATOR: Billy R. Lewelling, Tampa

COOPERATING AGENCY: Southwest Florida Water Management District

PROBLEM: In west-central Florida, the intermediate aquifer system occurs in parts of all of an eight county area. The aquifer is an important source of water in three of these counties because water in the deeper Floridan aquifer has a high mineral content near the Gulf coast. Rapid growth has taken place here the past five years, and in 1985, this was one of the leading growth areas of the state. Associated with this growth is an increased demand on water for public supply, industrial and agricultural uses. Extremes in water-level fluctuation need to be known to better manage the resources.

OBJECTIVES: A potentiometric surface map of the intermediate aquifer will be produced in May and September. A list of water level data will be prepared from the potentiometric surface maps. Hydrographs will be prepared for selected wells to show continuous water-level data. A brief text summarizing water-level conditions during the high and low water conditions will be prepared.

APPROACH: The water level monitoring network established for the "Hydrogeology of the intermediate aquifer system" project (FL-411) will be expanded and revised for this project for making semiannual water level measurements and producing a potentiometric map.

PROGRESS: The September 1986 potentiometric surface map was published. Network wells were measured in May and September 1987. The May 1987 map was prepared and submitted for review. The scope of study was expanded to include mapping the potentiometric surface in two water bearing units of the intermediate aquifer system. Previous maps showed only a composite surface from wells open to both units. Sea level datum was established for seven wells in the network.

PLANS FOR THIS YEAR: Complete the review process and publish the May 1987 potentiometric map. Collect water levels, draft, review and publish the September 1987 map. Inventory new wells to improve data base. Collect May 1988 water level data, draft and publish map. Collect water level data and prepare draft for September 1988 map.

REPORTS IN PROCESS: None

\section{REPORTS RELEASED:}

Lewelling, B.R., Potentiometric surface of the intermediate aquifer, westcentral Florida, September 1986: U.S. Geological Survey Open-File Report OFR 87-35, 1 map. 
FL-463 HYDROLOGY AND WATER QUALITY OF THE INTERMIEDIATE AND UPPER FLORIDAN AQUIFERS, HARDER AND DESOTO COUITIES, FLORIDA

DATE PROJECT BEGAN: October 1986

DATE PROJECT ENDS: September 1990

PRINCIPAL INVESTIGATOR: A. D. Duerr, Tampa

COOPERATING AGENCIES: Southwest Florida Water Management District

PROBLEM: Hardee and DeSoto Counties are experiencing increases in population and expansion of industry and citrus groves. Because of the increase in population and water use, there is concern about the long-term impacts of increased withdrawals from the intermediate and upper floridan aquifers. There is a potential for degrading the quality of water in the upper aquifers due to improper well construction, such as open hole in multiple zones containing water of varying quality.

OBJECTIVES: The purpose of the study is to identify the major aquifers, define their lateral extent, identify areas where they are interconnected, and describe the hydraulic and water-quality characteristics of each aquifer.

APPROACH: Field data collection will include an inventory of existing wells, collection of geologic and water-quality samples during drilling of new wells, collection of geophysical data, aquifer tests, and collection of water-quality samples and water-level data from existing wells. Maps will be prepared showing the thickness and lateral extent of the intermediate and upper Floridan aquifers. Potentiometric surface maps will be drawn and the lateral and vertical varlations of selected water-quality parameters will be mapped. Seepage runs will be conducted on the Peace River to study the relation between ground and surface water and to identify areas of recharge and discharge.

PROGRESS: The planning document, project description, revised project proposal, preliminary report outline, and base map were prepared. A literature and data search were completed. The ten percent peer review was conducted in March. An inventory of wells for inclusion in water-level network and for water-quality sampling was initiated. Water samples were collected from 15 wells and were analyzed for dissolved solids, hardness, chloride, sulfate, fluoride, iron, $\mathrm{pH}$ specific conductance, silica, boron, and nutrients. Field inspection of ROMP sites $30,31,26,16$, and 17 were made and land owners were contacted to locate privately-owned wells that could be utilized for aquifer tests. Permits were obtained to drill additional observation wells at two ROMP sites (17 and 31 ).

PLANS FOR THIS YEAR: Continue collecting water-quality data. Drill three observation wells near ROMP sites 17 and 31 , and conduct aquifer tests. Conduct seepage runs on the Peace River. Examine data from newly-drilled wells to further define the top, thickness, and lateral extent of the intermediate and Upper Floridan aquifers. 


\section{FL-464 SALTWATER INTRUSION IN SPRINGS ALONG THE COASTAL MARGIN}

OF CITRUS AND HERNANDO COUNTIES, FLORIDA

DATE PROJECT BEGAN: October 1986

DATE PROJECT ENDS: September 1990

PRINCIPAL INVESTIGATOR: D. K. Yobbi, Tampa

COOPERATING AGENCIES: Southwest Florida Water Management District

PROBLEM: Because of the potential for increased saltwater intrusion due to expanding use of groundwater, it is important to develop a better understanding of coastal springs and their role and relationship to the hydrology of the area. Insufficient data exist for evaluating the dynamics associated with seawater and the level and quantity of freshwater in coastal springs. Such data collection and development of hydrologic relations are needed to understand coastal spring hydrology and requirements to maintain healthy estuaries.

OBJECTIVES: To collect and analyze data to define movement of saltwater in springs along the coastal margin of Citrus and Hernando Counties.

APPROACH: Water quality and streamflow measurements will be made over a range of hydrologic conditions. Continuous recording streamflow, tidestage, and water quality monitoring stations will be established on selected springs. Near major springs, recording water-level and water-quality stations will be established on selected wells. A well inventory and testdrilling program will be conducted. Ground-water levels will be measured and potentiometric maps prepared. Surface-geophysical techniques will be applied over a range of hydrologic conditions.

PROGRESS: Project proposal was revised in response to cooperator's comments. A literature and data search was completed. Alternate types of sample analysis were investigated, including the use of various isotopes for defining the source and age of water discharging from the springs. Field reconnaissance surveys were conducted and background water-quality samples were collected at selected springs.

PLANS FOR THIS YEAR: Two springs and two wells will be selected and equipped with water-level and water-quality recorders for the continuous collection of water-level, specific conductance, and temperature measurements. Tidal-cycle discharge measurements and water-quality samples will be collected as needed. Ground-water levels will be collected to supplement district-wide sampling. 
FL-465 POTENTIAL FOR CONTAMIMATION OF THE FLORIDAN AQUIFER SYSTEM, UEST-CENTRAL FLORIDA

DATE PROJECT BEGAN: October 1986

DATE PROJECT ENDS: September 1990

PRINCIPAL INVESTIGATOR: Craig B. Hutchinson, Tampa

COOPERATING AGENCIES: Southwest Florida Water Management District

PROBLEM: West-central Florida is undergoing rapid growth and in some areas, water is already in short supply. The Floridan aquifer system supplies more than 90 percent of the freshwater used in west-central Florida. Areas that are particularly vulnerable to contamination occur where the Floridan aquifer system-is near land surface or where recharge to the aquifer is rapid. Recently, the pesticide EDB, used only for the past 30 years, has been detected in water from the Floridan aquifer system. In order to safeguard the water supply, the potential for water quality degradation in the Floridan aquifer system must be assessed.

OBJECTIVES: Map hydrogeologic conditions suspected to rapidly convey recharge to the upper Floridan aquifer. Develop data base of existing radiochemical and stable isotopes in the SWFWMD. Evaluate chemical, radiochemical, and stable isotope methods used to indicate relatively recent recharge water. Supplement data base of radiochemical and stable isotopes in the SWFWD. Use hydrogeologic and chemical data to map qualitatively the potential for contamination of the Floridan aquifer system.

APPROACH: Make a qualitative assessment of susceptibllity based on available hydrogeologic information and prepare a preliminary map of pollution potentials. Field test geochemical ground-water age dating methods, such as tritium, deuterium, oxygen-18, partial pressure of $\mathrm{CO}^{2}$, redox potential, saturation indices and the presence of compounds such as EDB, 24-D, stilbenes and alkyl benzene sulfanate. About 30 wells will be sampled to validate these methods. About 90 additional wells will be sampled throughout SWFWMD in order to identify relatively recent recharge areas. The existing geochemical data base and preliminary pollution potential map will be updated and an interpretive report will be written.

PROGRESS: The project proceeded on schedule during fiscal year 1987 . A planning document was prepared and a literature review was conducted. USGS water-quality files and private consultants reports were used to compile a list of contaminated wells and a data base of environmental isotopes. Maps of hydrogeologic properties of the Southwest Florida Water Management Dis trict were digitized and overlay techniques were used to delineate two test areas for intensive sampling. Wells that tap the upper part of the Floridan aquifer system were inventoried in each test area. Six wells were sampled in the southern test area, which has a low susceptability to contamination. Twenty-four wells were sampled in the highly-susceptible northern test area. 
All wells were sampled for field $\mathrm{pH}$, alkalinity, specific conductance, dis solved oxygen, and EH. Samples were sent to various laboratories for analyses of common ions, detergents, volatile organic compounds, sulfide, and environmental deuterium, oxygen-18/oxygen-16, and tritium.

PLANS FOR THIS YEAR: During FY88 results of sampling in the test areas will be studied to select parameters that are reliable indicators of ground-water age and the potential for contamination. About 90 wells will be inventoried to provide an even distribution of sampling sites within the SWFWMD area where the Floridan aquifer system may be susceptible to contamination. Several of the wells will be sampled for selected water-quality parameters. 
FL-466 FLORIDAN AQUIFER SYSTEY WATER QUALITY IN AN AREA OF DRAIKAGE-WETI INFLOW

DATE PROJECT BEGAN: October 1986

DATE PROJECT ENDS: September 1989

PRINCIPAL INVESTIGATOR: Edward H. Martin, Orlando

COOPERATING AGENCY: Florida Department of Environmental Regulation

PROBLEM: The Floridan aquifer system serves as the principle source of drinking water for the area. Because of the dual usage of the Floridan aquifer system, there is a potential for contamination of the area's drinking-water supply by drainage-wells. Studies aimed at investigating the effect of drainage-well inflow on water quality in the Floridan aquifer system have not revealed any widespread water-quality problems. There was no evidence of a direct link between supply water quality and drainage-well proximity. Study of areas downgradient of drainage wells having large inflows is needed to determine if contamination of the aquifer system is occurring.

OBJECTIVE: To determine the impact of drainage well inflow on the quality of water in the Floridan aquifer in the vicinity of drainage wells.

APPROACH: Inventory and evaluate potential sites. Select 2 to 3 sites for intensive investigation. Drill additional wells at the selected sites as necessary. Use geophysical logging to determine characteristics of the drainage wells and the depth. Install and operate a water level, specific conductance, and temperature recorder on one of the monitor wells at each study site. Sample wells near end of dry season, several weeks after onset of wet season, and after wet season has ended. Sample sediments.

PROGRESS: Began well drilling for monitoring wells. Initial sampling of other existing wells completed. Initial literature search completed and references collected. Significant results include the finding of hydrocarbons and other constituents related to storm runoff. Other results include water quality data that show recent influence of drainage well inflow, such as high tritium values, high nitrogen concentrations, and other constituents that indicate high recharge.

PLANS FOR THIS YEAR: Collect daily water level and water quality data from monitoring wells. Sample and identify problem sites and analyze all data. 
FL-468 WATER RESOURCES OF DUVAL COUNTY, FLORIDA

DATE PROJECT BEGAN: October 1986

DATE PROJECT ENDS: September 1989

PRINCIPAL INVESTIGATOR: Eugene C. Hayes, Orlando

COOPERATING AGENCY: City of Jacksonville

PROBLEM: Jacksonville is rapidly increasing in population and expanding commercially and industrially. As a result, areas that were once rural are now becoming urbanized and stresses are being placed on the physical environment including the quality and quantity of water supplies. A large amount of hydrologic data has been obtained and many technical reports have been prepared as a result of 27 years of investigations. Most of the reports are moderately to highly technical and were prepared mainly for the scientist, engineer, and professional water manager. A non-technical report is needed, prepared from historical data, to help educate the public on vital aspects of the water resources of Duval County. Proper management of the system cannot occur without the cooperation of an informed public.

OBJECTIVE: The principal objectives of this investigation and resulting report are to summarize and interpret some of the major results of the 27year program of investigation of the water resources of Duval County and northeast Florida in a manner that will be useful to local citizens as well as to the scientific and professional water manager. Specifically, the report will be prepared using STOP FORMAT and present (1) the source, occurrence, and movement of water in Duval County (natural hydrologic system and (2) the effects of man's activities on the system.

APPROACH: (1) Collect, synthesize, and interpret historical information from published and unpublished reports and maps and from records of the U.S. Geological Survey and from other sources as avallable and necessary; (2) prepare the resulting Water Atlas report using STOP FORMAT. Where possible maps for illustrations will be generated from the GIS ARC-INFO data base. New layers of information will also be generated and stored in a Duval County data base accessible to the cooperator using an IBM PC-XT.

PROGRESS: All historical information available from U.S. Geological Survey and the City of Jacksonville files have been collected.

PLANS FOR THIS YEAR: Additional data layers will be prepared during FY88. 
FL-471 GROUND-WATER QUALITY IN THE VICINITY OF STORMWATER

PONDS, PINELLAS COUNTY, FLORIDA

DATE PROJECT BEGAN: October 1986

DATE PROJECT ENDS: September 1989

PRINCIPAL INVESTIGATOR: Mario Fernandez, Tampa

COOPERATING AGENCY: Pinellas County

PROBLEM: The effects of ground-water alterations by stormwater detention ponds is covered by Chapter 17-31404(2), Florida Administrative Code. During the wet season, ponds located into the water table will recharge the aquifer only when there is a head difference between it and the surrounding water level. Polyaromatic nuclear hydrocarbons have been found in pond sediments. Phenols have been detected in pond sediment and water.

OBJECTIVE: To investigate inorganic and organic contaminants in ground water near stormwater ponds and bottom deposits in ponds receiving runoff from residential and commercial/urbanized areas; to evaluate the effects of the ponds on the ground water at each site; and attempt to determine the direction of migration of leachate from the ponds.

APPROACH: Bathymetric surveys will be used to locate pond sediments. Wells located in the water table will be used for water-quality and water-level measurements. Direction of ground-water will be established. Ground- and surface-water samples and pond sediments will be collected for analysis of inorganic and organic constituents.

PROGRESS: Three stormwater detention ponds were selected for investigation. One pond is in a highly developed residential and commercial area; another is in an all residential area. The third pond is also in an all residential area but was excavated less than one year ago and will serve to define background conditions. Wells were installed in the surficial aquifer to monitor water levels and to collect water samples for analysis. A bathymetric map was made of each pond to determine areas where silt could accumulate. Sediment samples were collected from each pond for chemical analyses. Boreholes were drilled and soll cores collected for determination of soll physical properties.

PLANS FOR THIS YEAR: Water levels will be measured and a water table map with direction of ground-water movement will be prepared. Ground and surface water and pond sediments will be collected for chemical analysis. Work will begin on the final report. 


\section{FL-472 HYDROGEOLOGICAL ASSSESSMENT OF SPRAY EFFLUENT AND SLUDGE DISPOSAL BASINS AT A DISPOSAL SITE, PINELIAS COUNTY, FLORIDA}

DÁTE PROJECT BEGAN: October 1986

DATE PROJECT ENDS: September 1990

PRINCIPAL INVESTIGATOR: John T. Trommer, Tampa

COOPERATING AGENCY: Pinellas County

PROBLEM: Results of previous water-quality monitoring at the Northwest Pinellas County sewage treatment plant effluent and sludge disposal sites and private wells, have indicated increasing concentrations of some chemical constituents. The treatment plant is located in an area of rapid urban development, and water from a private well to the south is beginning to show changes in water quality. Because the general direction of ground-water movement is toward the west, privately owned wells in that direction also may begin to show water-quality changes. The overall effects of the disposal system on the surrounding environment has not been evaluated.

OBJECTIVE: To determine if land application of effluents and fertilizers at a nearby resort to the east is migrating through the groundwater into the site; to determine the extent that effluent and sludge disposal operations have affected ground-water quality at the disposal site and in areas downgradient from the site; to conduct a reconnaissance of downgradient private wells to determine whether they have been, or will be affected by the dis. posal operations.

APPROACH: All existing water-quality and hydrologic data will be evaluated. A surface geophysical survey will be conducted using resistivity and electromagnetic methods to locate and delineate any plumes. About 20 additional wells will be drilled to monitor water quality and water levels. In addition, three 4-inch wells will be installed in order to determine aquifer characteristics and rate of ground-water movement. Samples will be collected and analyzed for nutrients, metals, herbicides, pesticides, volatile organic compounds, and priority pollutants; standard complete Flame Ionization Detection (FID), gas chromatography and standard lab analyses will be used.

PROGRESS: The planning document and report outline were prepared. A literature and file search was conducted to locate all material pertient to this study. The location and condition of existing wells was evaluated and, where necessary, wells to be used in the study were repaired. Resistivity and electromagnetic surveys were run to locate possible leachate plumes. These surveys were ineffective for locating plumes, possibly because effluent had not been sprayed at the site for about 30 days, or the effluent does not contain chemical constituents in high enough concertrations to differentiate it from surrounding groundwater. The resistivity survey and some geophysical well logging were useful, however, in defining geology at the site. Water-quality samples were collected at the site and analyzed for nutrients, organic and inorganic consituents, trace elements and volatile 
(FL472)

organic compounds. Seventeen addition surficial aquifer monitor wells, 4 upper Floridan aquifer monitor wells and 3 surficial aquifer test wells were drilled at the site. Preliminary maps of the topography and location of the study area and location of sampling sites were prepared.

PLANS FOR THIS YRAR: Ground penetrating radar will be used to further define the geology and subsurface features at the study site. Core samples collected during previous drilling will be sent to the University of South Florida to be analyzed for physical properties and mineralogy. Water levels In all wells will be measured periodically and preliminary estimates of direction of flow will be made. Water quality samples will be collected and analyzed for trace elements, volatile organic compounds, nitrients, and methylene blue active substance. Some additional samples may be collected for virus and coprostanol to help determine source and extent of any possible pollution. An annotated outline and the introduction and methods section of the report will be written. 


\title{
FL-473 HYDROLOGIC IMPACTS OF PHOSPHATE MINING ON SMALL
} BASINS, CENTRAL FLORIDA

\author{
DATE PROJECT BEGAN: April 1987 \\ DATE PROJECT ENDS: March 1992
}

PRINCIPAL INVESTIGATOR: Terry $\mathrm{H}$. Thompson, Tampa

COOPERATING AGENCY: Florida Institute of Phosphate Research

PROBLEM: The hydrologic characteristics of small basins in central Florida are poorly defined. Permits for mined-land reclamation require that runoff from reclaimed land not exceed pre-mining conditions and there be no degradation of water quality of the receiving stream. There are no data on the hydrologic characteristics of reclaimed land forms.

OBJECTIVE: (1) Define the hydrology and water quality of undistributed small basins in the phosphate mining area of central Florida; (2) define the hydrology and water-quality characteristics of the four most common reclaimed land forms: a clay settling area, land and lakes (graded overburden) area, in sand-clay mix settling area, and an overburden capped sandtailings fill area; ( 3 ) compare results from 1 and 2 above; (4) develop models to predict the hydrologic characteristics of various reclaimed land forms.

APPROACH: Collect hydrologic data from small undisturbed basins and from four nearby basins representing the common reclaimed land forms to define streamflow and aquifer characteristics. Collect ground-water samples during high and low water table conditions to define ground-water quality. Collect streamflow samples during baseflow and during related storm runoff to define water quality of streamflow. Compare and describe statistical differences between unmined and reclaimed basin pairs and among various reclamation types. Develop rainfall-runoff models to predict runoff characteristics of various reclaimed land forms.

PROGRESS: Numerous mining and chemical companies were contacted about availability of sites for study that were accessible and had been reclaimed using common reclamation methods. About 20 basins were field checked for suitability for inclusion on the list of sites to be presented to the technical advisory committee (TAC) and the Board of Directors of the Florida Institute of Phosphate Research. Based on the TAC review, eight small basins in central Florida were selected for study. They include three unmined basins that range in size from 88 to 460 acres, and five reclaimed basins ranging in size from 75 to 450 acres. The reclaimed basins include two clay-settling areas, a land and lakes area, a sand-clay mix settling area, and an overburden capped sand-tailings fill. A planning document was prepared and submitted to the cooperator. 
(FL-473)

PLANS FOR THIS YEAR: Monitor sites will be established on five reclaimed mine drainage basins and three nearby unmined basins. Each drainage basin will have a monitor network that includes a continuous streamflow station, two rain gages, ten small-diameter observatory wells for periodic measurement of the water table, a large-diameter well for continuous observation of water table, and a deep well for monitoring the intermediate aquifer. Reclaimed basins will be paired with unmined basins having approximately the same size catchment area. Each streamflow station will include a minimonitor to collect continuous conductivity and temperature data during flow events and a stage-activated automatic pumping sampler that will collect up to 24 water-quality samples during storm runoff. 


\section{FL-474 EFFECTS OF STRUCTURAL CHANGES ON THE WATER-QUALITY EFFICIBNCY OF STORMTATER DETENTION POND}

\section{DATE PROJECT BEGAN: January 1987}

DATE PROJECT ENDS: September 1990

PRINCIPAI INVESTIGATOR: Edward H. Martin, Orlando

COOPERATING AGENCY: Florida Department of Transportation

PROBLEM: It is reasoned that if the velocity of the water entering a detention pond is dramatically decreased immediately inside the pond, and if the travel time of the water within the pond is significantly lengthened, that an increased constituent load will settle to the bottom of the detention pond. These two hydraulic conditions can be brought about by constructing a baffle near the entrance culvert, and by placing a wall in the middle of the pond. These structural changes should increase the water-quality treatment ability of this detention facility.

OBJECTIVE: The primary objective of this investigation is to determine the effectiveness of selected structural changes to detention facilities for improving water-quality treatment. Secondary objectives include: determine and analyze the increased residence time, or detention time, due to the structural changes; and determine if the hydraulic conditions caused by the structural changes can be modeled, either with an existing model or one that is easily modified.

APPROACH: The first task is to perform a hydraulic study of the presently structured pond. Samples will be collected at nine sampling points within the pond. Separate tracer studies will be run at three different steadystate discharges. Analyses of these data will permit the calculation of the pond's hydraulic residence time(s), probably as a function of live storage or discharge.

Once the pond is restructured, about 10 to 15 storms will be gaged and sampled. The last task is to perform a hydraulic analysis of the restructured pond, analogous to the study completed in the first task.

PROGRESS: Instrumentation purchased and installed. Residence times for pre-reconstructing dye studies were performed. An abstract on results of the initial time of travel data was prepared and submitted to an ASCE conference.

PLANS FOR THIS YEAR: Cooperator will structurally change the study site. Post construction residence time and storm water quality sampling will begin. 
FL-475 EVALUATION OF THE DESIGN OF GROUND WATER QUALITY HONITORING NETWORKS IN FLORIDA

DATE PROJECT BEGAN: March 1987

DATE PROJECT ENDS: September 1989

PRINCIPAL INVESTIGATOR: Brlan G. Katz, Tallahassee

COOPERATING AGENCY: Federal

PROBLEM: A greatly increased national level of interest and funding in ground-water quality monitoring has occurred in the past few years. For example, a large data base has been developed in Florida to determine the extent of EDB (pesticide) contamination of ground water. Little detailed work has been done in terms of evaluating different network design strategies, applied to an existing data base, for characterizing the areal and vertical distribution of a contaminant in ground water.

OBJECTIVES: (1) To describe the regional distribution of EDB in ground water in Polk and Highlands Counties spatially and in association with various key factors such as hydrogeology and soll characteristics and (2) To evaluate different sampling strategles involving subsets of the entire EDB data base for describing the distribution of EDB in ground water.

APPROACH: The EDB data base will be evaluated using various statistical and spatial (GIS) techniques to determine the areal, vertical and temporal distribution of EDB in ground water. The efficiency of different network design strategies will be evaluated involving subsets of the original data base using systematic, stratified, and other sampling design approaches.

PROGRESS: Staffing and project planning have been completed. The EDB data base consisting of about 4,000 wells for Polk and Highlands Counties was retrieved from state files and converted to an INFO data base. Available well-construction information for these wells has been gathered from water management district files, mail surveys, and drillers records.

PLANS FOR THIS YEAR: Continue to verify and input additional information on well construction data. Evaluate quality assurance data from different laboratories who have performed EDB analyses. Prepare maps showing the areal distribution of EDB in ground water for Polk and Highland Counties. Prepare grid patterns of different sampling densities and compare the resolution with which EDB contaminated areas can be delineated using different sampling densities. Statistically compare differences in regional probability of EDB contamination determined by systematic sampling techniques using grid patterns. 


\section{FL-476 IMPORTANCE OF HYDROLOGIC AND VEGETATIVE FACTORS TO FISH ECOLOGY IN A SEASONALLY INUNDATED FLOOD-PLAIN FOREST}

DATE PROJECT BEGAN: September 1987

DATE PROJECT ENDS: June 1988

PRINCIPAL INVESTIGATOR: Helen M. Leitman, Tallahassee

COOPERATING AGENCY: Game and Freshwater Fish Commission

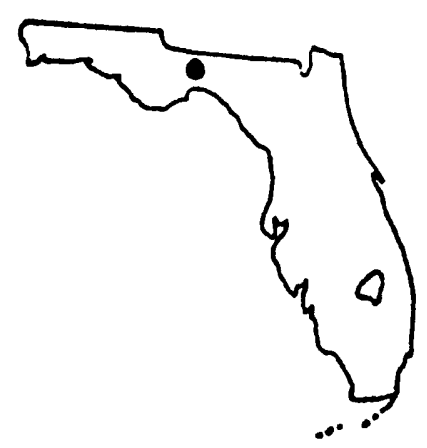

PROBLEM: River flood-plain forests are a valuable and productive national resource under considerable development pressure from agricultural interest. Ecological linkages between biotic and abiotic factors operating in river wetlands must be established if this important natural resource is to be properly managed. Habitat characteristics of the flood plain that are important to fish populations will be evaluated in an interdisciplinary study of an alluvial river in north Florida.

OBJECTIVE: Relate hydrologic conditions and vegetative communities to fish diversity and abundance in a seasonally inundated river flood-plain forest.

APPROACH: The 3-year study will require data collection and analyses by an interdisciplinary interagency team comprised of hydrologists, botanists, and fisheries biologists. USGS will quantify hydrologic fluctuations and characterize plant communities at the same locations and during the same time period that fish are sampled by the Florida Game \& Fresh Water Fish Commission.

PROGRESS: New Project.

PLANS FOR THIS YEAR: Conduct reconnaissance of flood plain in coordination with Florida Game and Fresh Water Fish Commission (FGFWFC) to select transects and sampling sites. Design and test fish and vegetation sampling methods. Survey elevations, identify trees and shrubs, sample ground cover vegetation seasonally, install simple crest stage gages and measure water depths monthly at each site. Assist FGFWFC with fish sampling seasonally, more often during floods. Prepare and submit annual progress report to cooperator. 
FL-477 AN EVALUATION OF VARIOUS PHYSICAL AND BIOLOGICAL INDICATORS USED TO DELINEATE WETLAND BOUNDARIES ON BLACKTIATER STREAM SYSTEAS IN FLORIDA

DATE PROJECT BEGAN: October 1987

DATE PROJECT ENDS: September 1990

PRINCIPAL INVESTIGATOR: Helen M. Leitman, Tallahassee

COOPERATING AGENCY: Florida Department of Environmental Regulation

PROBLEY: Protection of Florida's wetlands is entrusted primarily to the Florida Department of Environmental Regulation (FDER). River wetlands are of particular importance to the state because inflow of nutrients from freshwater river wetland systems are largely responsible for high productivity in estuaries. The proposed study will improve the management and regulation of blackwater stream wetlands by evaluating the various indicators used by FDER to delineate wetland boundarles on those systems.

OBJECTIVE: To quantitatively describe the occurrence of wetland plants, hydric soils, and other wetland indicators in flood-plain sites along several north Florida blackwater streams, and relate these indicators to duration of inundation.

APPROACH: The 3-year study will require data collection and analyses by an interdisciplinary interagency team comprised of hydrologists, botanists, and soil scientists. USGS will describe depth and duration of flooding at each site based on a long period of gage record. USGS and DER will work together to describe plant communities, soil types, and other hydrologic indicators at the sites. USGS will relate the various indicators to the long term hydrologic conditions at each site.

PROGRESS: New Project.

PLANS FOR THIS YEAR: Conduct reconnaissance of north Florida blackwater streams in coordination with Florida Department of Environmental Regulation (FDER) to select study sites on gaged streams. Survey sites to tie into long-term gages. Observe surface water and surficial water-table levels monthly at most sites. Locate and describe physical and biological indicators at all sites. Analyze long-term surface water records at each site. Assist FDER with preparation of annual progress report to cooperator. 


\section{FL-479 IMPACTS OF A MIGRATING CITRUS INDUSTRY ON THE WATER RESOURCES OF HARDEE AND DESOTO COUNTIES, FLORIDA}

DATE PROJECT BEGAN: October 1987

DATE PROJECT ENDS: $\quad$ September 1990

PRINCIPLE INVESTIGATOR: James L. Kiesler, Jr., Tampa

COOPERATING AGENCY: Southwest Florida Water Management District

PROBLEM: Citrus growers began to migrate southward after freezes in northern and central Florida devastated the citrus industry during the early $1980^{\prime} \mathrm{s}$. As growers moved south the need for water to irrigate citrus increased. Irrigated citrus acreage in Hardee and DeSoto Counties, Florida increased from 59,000 acres in 1980 to 82,000 in 1986. How has the hydrology of Hardee and DeSoto Counties, and southwest Florida, been affected by the increased irrigation. As additional growers move into this area what impact will the irrigation of their groves have on the hydrology? What are the long-term impacts of citrus irrigation on the hydrology of this area?

OBJECTIVES: (1) Evaluate the present and long-term impacts of the current citrus industry on the hydrology of Hardee and DeSoto Counties. (2) Develop a technique using GIS and mathematical models that will allow resource managers to evaluate the probable hydrologic impacts of future citrus expansion.

APPROACH: Existing continuous and periodic water-level data from wells in the two county area will be examined. The nonparametric Seasonal Kendall test will be used to test for monotonic trends in ground-water levels. Periods to be tested are the period of record, period prior to 1981 , and period after 1981. The nonparametric Mann-Whitney-Wilcoxon test will be used to test for step trends in water levels for the pre- and post-1981 periods. Monthly precipitation totals for Arcadia, Florida will be tested for trends in precipitation that may cause changes in ground-water levels. The McDonald-Harbaugh Finite-Difference Model will be used to generate longterm ground-water levels for the area for the present land-and water-use conditions and selected hypothetical conditions. The Seasonal Kendall and Mann-Whitney-Wilcoxon tests will be used to test for trends in the simulated data. A Geographical Information System will used to supply input to the model and used to store, display, and analyze model output.

PROGRESS: New project.

PLANS FOR NEXT YEAR: The first year of the project will be used to develop a work plan, perform a literature and data review, complete an annotated outline for the final report, compile existing data, perform the statistical analysis of existing data, and develop the data base needed to calibrate the mode1. 
FL-480 EVALDATION OF THE AKBIEAT GROUND-WATER MONITORING NETWORK FOR DESGRIBING BACRGROUND WATER QUALITY IN FLORIDA

DATE PROJECT BEGAN: October 1987

DATE PROJECT FNDS: December 1989

PRINCIPAL INVESTIGATOR: Brian G. Katz, Tallahassee

COOPERATING AGENCY: Florida Department of Environmental Regulation

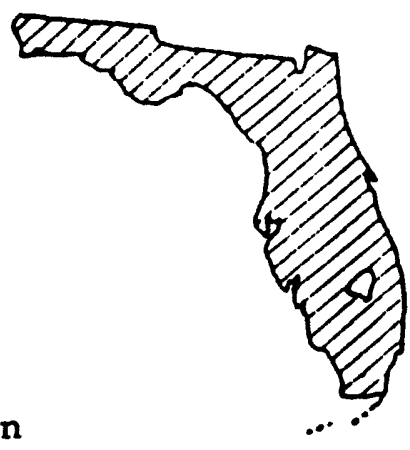

PROBLEM: Assessment of water-quality degradation due to human impacts required information on background (natural) water-quality characteristics. A statewide sampling network has been established to determine background water-quality conditions of principal aquifers in Florida. The data from the network need to be evaluated to determine if the sampling network is adequate for meeting program objectives and to outline long-term sampling needs.

OBJECTIVE: (1) To delineate hydrochemical zones that define areas of similar background water quality in Florida's aquifers on the basis of data from the statewide sampling network and other sources. (2) To evaluate the design of the statewide sampling network for long-term monitoring of background water quality of principal aquifers in Florida.

APPROACH: Geochemical and statistical methods will be used to characterize background water quality based on data from the sampling network. Zones of similar background hydrochemistry will be delineated based on spatial differences in the distribution and relative abundance of major ions and selected trace constituents. The sampling network design will be evaluated using geostatistical techniques and existing information on geochemical and hydraulic properties of principal aquifers.

PROGRESS: New Project.

PLANS FOR THIS YEAR: Obtain water-quality and well-construction data for the statewide ambient network. Screen water quality data for statistical outlines and chemical logic. Compile descriptive statistics for waterquality data by selected constituent and by aquifer. Delineate hydrochemical facies based on relative proportions of major ions. Define chemically district zones within hydrochemical facies. 
FL-481 THE RELATIVE IMPORTANCE OF GROUND WATER TO THE CHEMICAL BUDGET OF SEEPAGE LAKES

DATE PROJECT BEGAN: January, 1988

DATE PROJECT ENDS: December, 1991

PRINCIPAL INVESTIGATOR: T. M. Lee, Tampa

COOPERATING AGENCY: Florida Department of Environmental Regulation

PROBLEM: Progressive acidification of lakes in Scandinavia, eastern Canada, and the northwestern United States has led to decline and/or loss of fish species, benthic invertebrates, phytoplankton, zooplankton, and other organisms. Similar losses could occur in many Florida lakes that are known to have low acid-neutralizing capacity, particularly since the acidity of Florida's rainfall has increased over the last 25 years. At the present time it is impossible to assess the probable effect of acidic rainfall on Florida's most susceptible lakes (seepage lakes having no stream inflow or outflow) because of the lack of information regarding groundwater contributions to the chemical budget.

OBJECTIVES: (1) To understand the factors that regulate acid-neutralizing capacity in seepage lakes, particularly the importance of ground-water contributions, (2) to improve our conceptual and physical models of the hydrologic and chemical processes effecting the chemistry of seepage lakes, and (3) to use these models to predict the vulnerability of seepage lakes to changes in acidic deposition or alterations in ground-water flow.

APPROACH: Two seepage lakes (Lucerne and Barco) having different acidneutralizing capacities will be compared and contrasted using both hydrologic and chemical budgets. All terms in the hydrologic budget will be independently determined to minimize errors. Direct measurements will be made if possible. Evaporation will be computed using both mass-transfer and energybudget techniques. Ground-water flow will be determined by a combination of flow net, numerical modeling, and seepage meter techniques. Determination of acid deposition on the lakes, solute concentrations in both lake and ground waters, deposition and release of ions from lake sediments, and availability of the hydrologic budget will allow construction of a detailed chemical budget of each lake. The chemical budgets will be applied to determine lake susceptibility to acidification.

PROGRESS: New Project.

PLANS FOR THIS YEAR: A work plan and annotated outline of the final report will be prepared. Existing data will be compiled. Ground-water monitoring wells will be installed. Lake bathymetry and sediment distribution will be determined. Groundwater models will be initiated. 


\section{FL-482 FINE SEDIMGAT RESUSPEISION PROCESSES AND LIGHT ATTENUATION}

II SHAIIOH ESTUARINE ENTIRORTGATS

DATE PROJECT BEGAN: OCtOber 1987

DATE PROJECT EADS: September 1991

PRINCIPAI INVESTIGATOR: David H. Schoellhamer, Tampa

COOPERATING AGENCIES: City of St. Petersburg, C1ty of Tampa, Hillsborough County, Pinellas County, Tampa Port Authority

PROBLEM: One of the most potentially damaging effects of urbanization on estuaries is an increase in the amount of fine suspended material in the water column and the associated decrease in light penetration of the water column. Because light is needed for photosynthesis, al1 submerged marine plants (such as seagrasses, benthic algae, and phytoplankton) are adversely affected by reduced light penetration. Tampa Bay, Florida, is an example of a shallow estuary that appears to be adversely impacted by decreased light penetration of the water column. Over 808 (62,000 acres) of its seagrasses have been lost since 1876. A probable cause for seagrass disappearance is the presence of suspended fine material in the water column which effectively limits the intensity of sunlight needed for seagrass photosynthesis to only the shallowest water depths, generally along the immediate shoreline. The most likely source of fine suspended material is resuspension from the bed of the bay.

OBJECTIVE: The objectives of this investigation are to determine the effect of fine sediment and its resuspension on light attenuation and to determine the mechanisms that cause resuspension of fine sediments in Tampa Bay.

APPROACH: Five pairs of suspended solids and current meters will be deployed throughout the water column on a vertical string at three sites in Tampa Bay (one site at a time). Periodic measurements will be made of light penetration, water quality parameters, and longitudinal suspended solids gradients. Data analysis will determine the relation between ilght attenuation and resuspension, the importance of other sources of light attenuation, and the mechanisms that cause resuspension. Before the instruments are deployed, a map of the sediments on the bed of the bay will be prepared and used to identify deployment sites and the instruments will be tested by measuring the sediment flux between Bayboro Harbor and Tampa Bay.

PROGRESS: Collection of data needed to map the areal extent of fine sediments on the bed of Tampa Bay is nearly complete.

PLANS FOR THIS YEAR: The sediment mapping, Bayboro Harbor instrumentation test, and full instrument deployment at a site in Hillsborough Bay (northeast portion of Tampa Bay) will be completed. 